\title{
PROCEEDINCS OF THE
}

\section{TWENTY-NINTH ANNUAL MILITARY \\ LIBRARIANS' WORKSHOP}
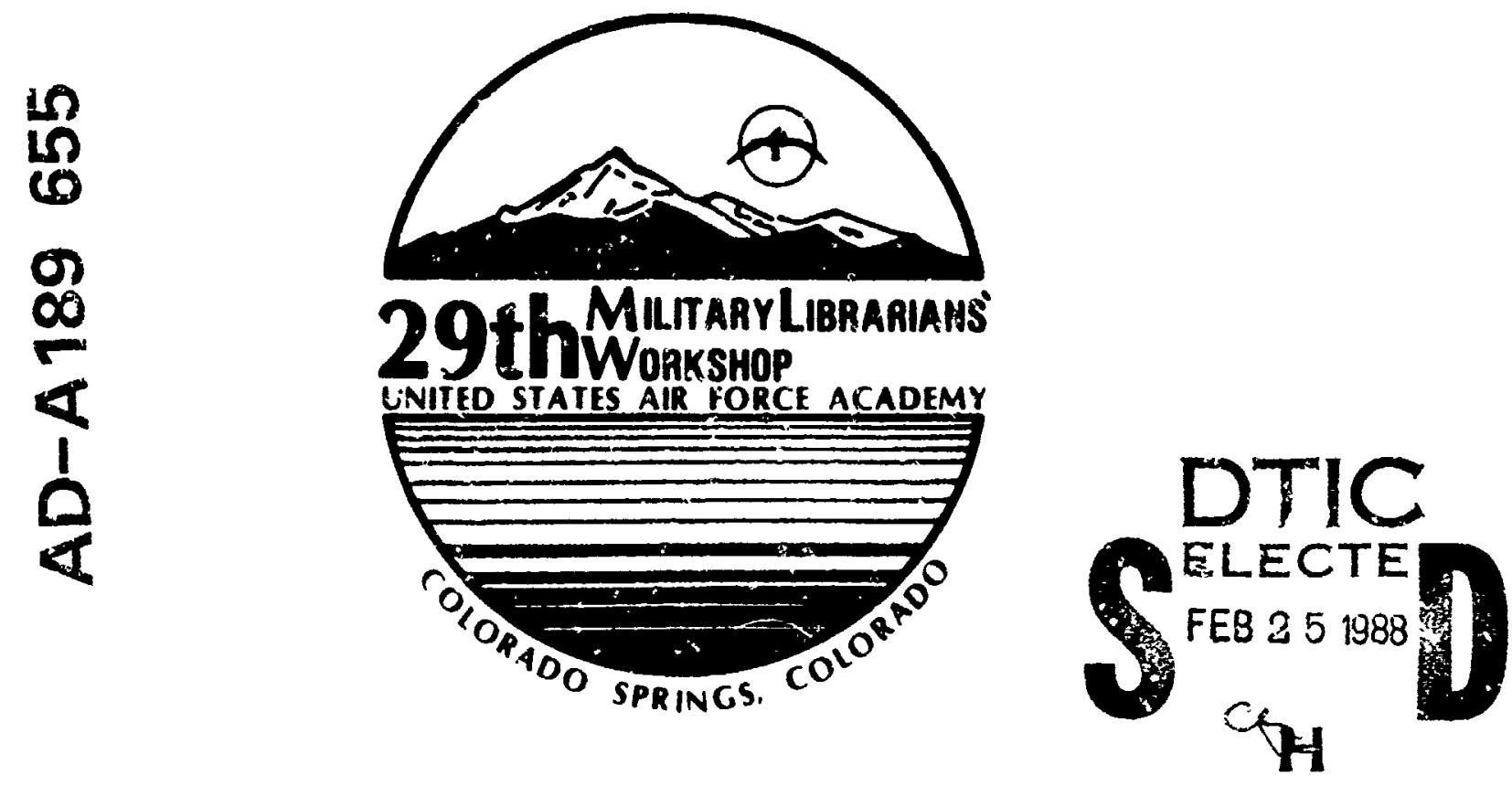

The Military Librarian As a Manager-We Win With People

\section{\begin{tabular}{c} 
DISTREB UTION STATEMETI $~$ \\
\hline $\begin{array}{c}\text { Approved for public relinwes: } \\
\text { Distr bution Unlimited }\end{array}$
\end{tabular}}

Hosted by

the U. S. Air Force Academy

$$
\text { (9-11 Oct 1985) }
$$

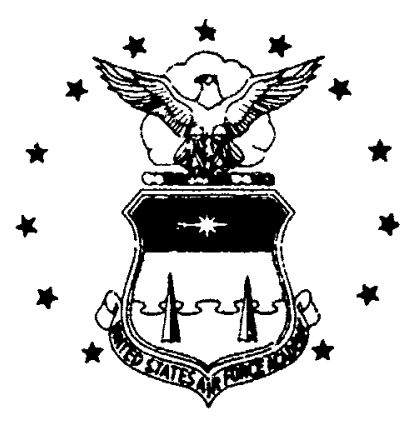

88225103 




\section{APPBUDICES}

\section{United States Mir Force Mcadeny}

- Air Force Academy History

$I-A-1$

-Air Force Academy Cadet Chapel

-The Falcon

$I-B-1$

-Gimbel Aeronautical History Collection

$I-C-1$

$I-D-1$

II. Uriting for Executives" Course Book

$$
\text { II- } 1
$$

III. Sources or Infornation on Hicroconputers in Libraries

IV. List of Previous Military Librarians' Uorkshop Hosts

$I V-1$

Y. List or Speakers

$\mathrm{V}-1$

VI. List of Ittendees

VI- 1

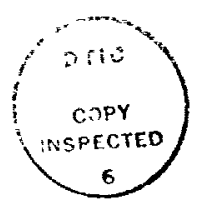

\begin{tabular}{|l|}
\hline Accession For \\
\hline NTIS GRAzI \\
DTIC TAB \\
Unannounced \\
Justifioation \\
\hline By PON He \\
Distribution/ \\
Aveliability Codea \\
\hline uist Avali and/or \\
Spocial
\end{tabular}




\section{TH AHLOLL MILITARY LIBRARIAHS' YORYSHOP}

\section{SPOESOR}

UNITED STATES AIR FORCE ACADEMY

Lt Gen Winfield W. Jcott, Jr.

Superintendent

\section{HOST}

Lt Col Reiner H. Schaeffer

Director of Academy Libraries

\section{BIECUTIVB BOARD}

Mr. Paul Klinefelter, Defense Technical Information Center, Chairman

Mr. Tony Dakan, Air Force Manpower and Personnel Center

Ms. Betty L. Fox, Defense Nuclear Agency

Ms. Pearl Robinson, Naval Ship Systems Engineering Station

Mr. Normand C. Varieur, U.S. Army Armament Munitions and Chemical Command

\section{PROGRAM COMIITER}

Lt Col Reiner H. Schaeffer

Capt James A. Robb, II

Mr. Donald J. Barrett

Ms. Lee R. McLaughlin

Ms. Maydeen Maisa (Administration)

\section{EDITORS}

Lt Col Reiner H. Schaeffer.

Capt James A. Robb, II

Ms. Maydeen Maika 


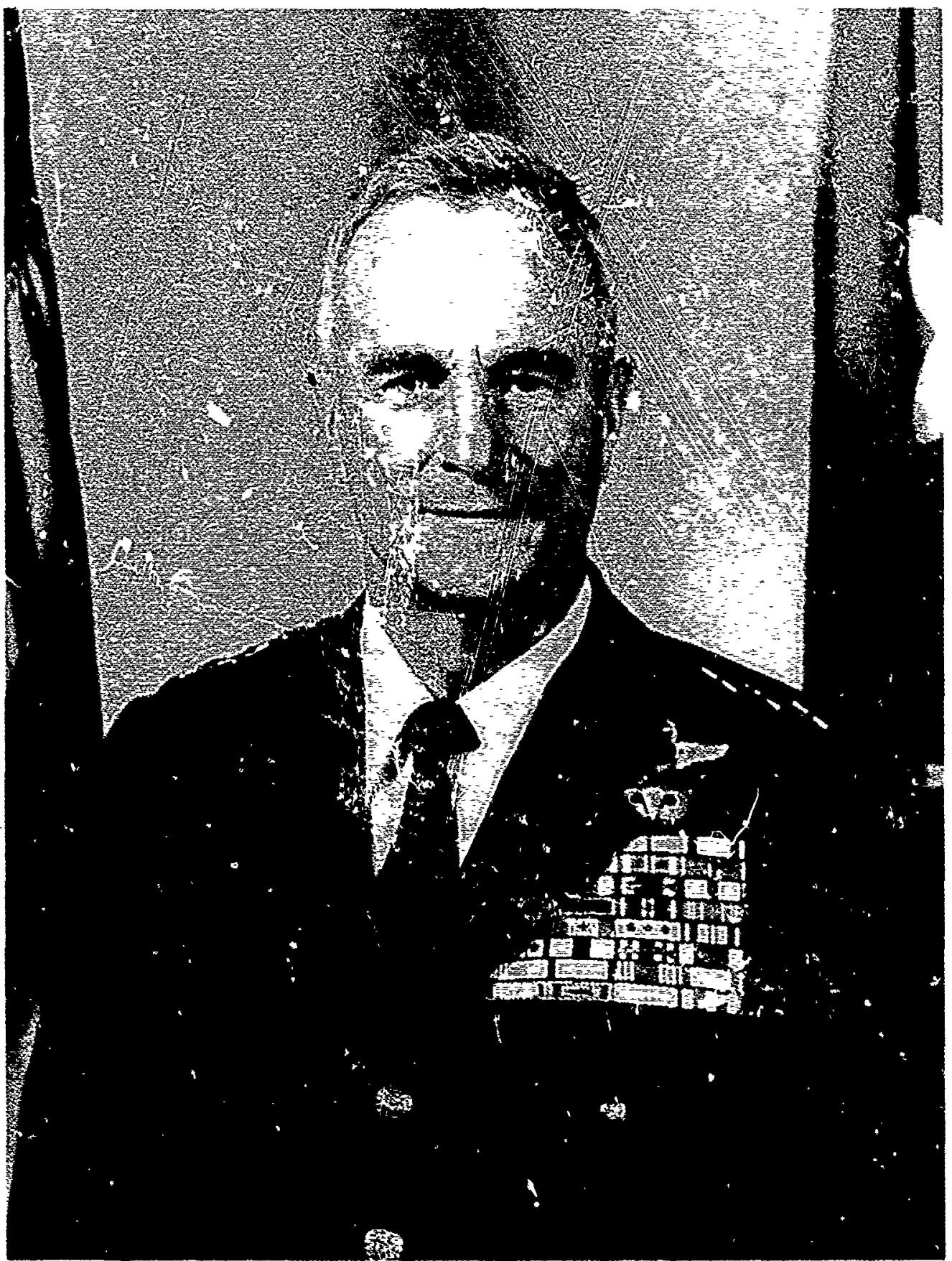

Lt Gen Winfield W. Scott, Jr. Superintendent

United States Air Force Academy 

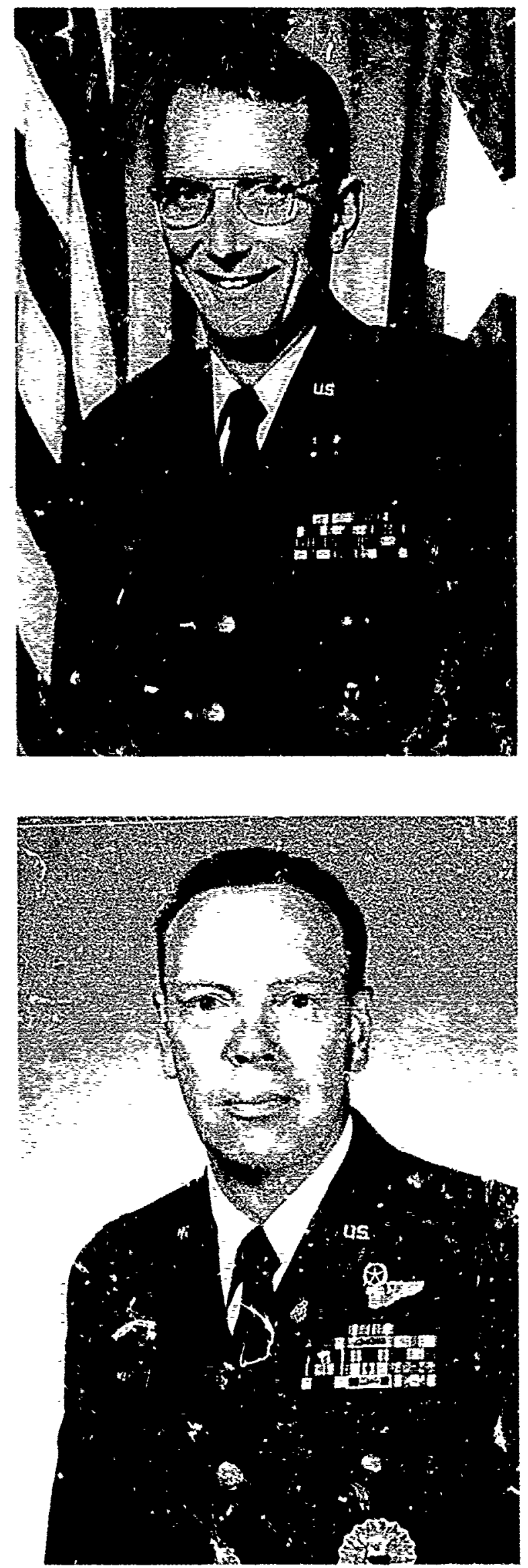

Brig Gen Ervin J. Rokke

Dean of the Paculty

United States Air Force Academy
Col John in. May

Vice Dean of the Faculty United States Air Force Academy 


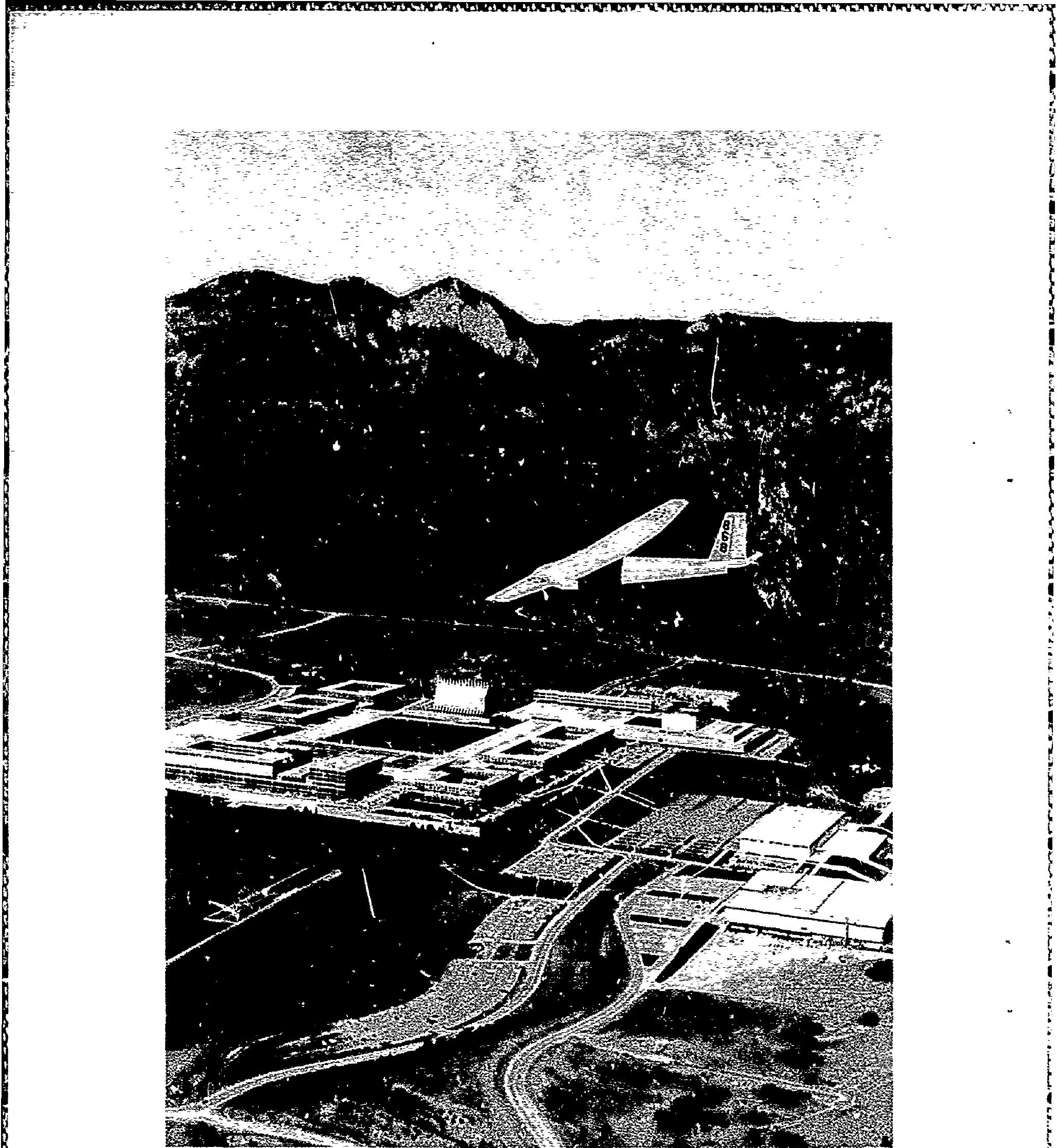

CADET AREA

UNITED STATES AIK FORCE ACADEMY 


\section{Preface}

Our main objective in planning this workshop was to present a program that not only "informs" attendees about the complexities of the management process, but also challenges each participant to take home some new knowledge and apply it in his/her own library arena. We believe oun program with the theme, "The Military Librarian As a Manager--We Win With People," achieved this goal.

While we have summarized only some of the workshop's co:atent and materials in these proceedings, we believe that this booklet will also serve as a future reference to attendees and as a source of general information for librarians who could not attend the workshop.

My special thanks go to the Superintendent, Lt Gen Winfield W. Scott, Jr., for making the Air Force Academy facilities available during this conference and for supporting this event so excellently through the various mission elements, especially through the Director of Conferences, Ms. Janet Shea, who did an absolutely superb job.

I would also like to recognize the Colorado Springs Hilton Inn staff, specifically Ms. Earbara Kliipers, Director of Sales, who provided not only first-class facilities but also excellent, professional service.

The key to this successful workshop was obviously my dedicated Library staff, particularly Mir. Don Barrett, Capt Jim Robb, Ms. Lee McLaughlin, and Ms. Maydeen Maika, whose hard work--from the initial brainstorming session to the completion of the workshop--never ceased. I'm very thankful to all of them for their help and expertise.

Also, I applaud all of our special speakers for their outstanding presentations: Col John May for his Welcoming Remarks; Lt Col Bob Pizzi for presenting "The Military Librarian As a Manager" and "Why and How We Win With People;" Lt Col Bill McCarron and Major Jon Eller for the "Writing for Fxecutives" lesson; Maj Bill Clover for the presentation of "Motivation and Leadership in Libraries;" Maj jon Stevens for his seminar on "Microcornputers in Libraries;" $\mathrm{D}:$. Barbara Schindler Jones for her serinar on "Organizational Communication in Litraries;" Dr. Freeman Rader for the "Communication Briefing Techniques;" Lt Col Tom McCann for the Air Force Academy Academic Briefing; Lt Col Bruce Doyle for the special presentation of "Pilgrimage" and audiovisual support throughout the conference; and, of course, our two cadets, $C 1 C \mathrm{Michael} \mathrm{T}$. Fursyth and $\mathrm{C} 1 \mathrm{C}$ Carolyn $M$. Reed for enlightening the audience alout our fine institution.

I also thank the members of the MLW Executive Board Committee, and especially my friend and colleague, Mr. Paul Klinefelter, for their strong support for our conference. Finally, my staff and I thank all our fellow attendees for their enthusiastic participation.

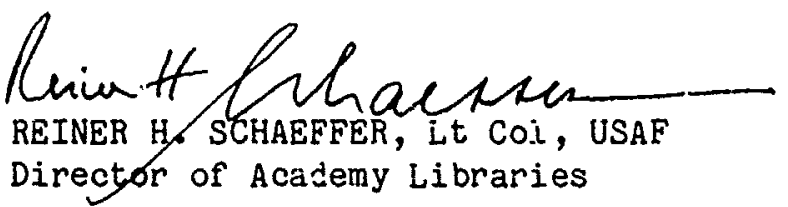




\section{TUBHTY-EIETH AHULL MILITART \\ LIBRARIAIS * VORLSHOP \\ (9-11 Oct 1985)}

PROGRAM

USAF ACADEMY, COLORADO SPRINGS, CO 80840

HILTON INN

505 Popes Bluff Trail

Colorado Springs CO

(303) 598-7656

IHEHE: "The Hilitary Librarian As a Hanager--

We Uin Uith People*

TURSDAI ( 8 OCT)

$1700-2100$ Registration Lobby

Dinner (On Your Own at Hotel or Nearby Restaurant)

UEDIESDLI ( 9 OCT)

$0630-0800 \quad$ Breakfast (On Your 0,wn)

$0630-0800 \quad$ Registration continued

(Coffee and Sweet Rolls)

Foyer

GENERAL SESSION

Ballroom

$0800-0815$ Welcoming Rern: :

(Lt Col Reiner H. Schaeffer,

Director of Academy Libraries)

0815 - 0915 "The Military Librarian as a Manager"

(Lt Col Robert E. Pizzi, Department of Management)

0915 - 0945 BREAK (Prepare for Trip to USAFA)

$0945 \quad$ Board buses

Front Entry

$1010-1215$ TOUR OF ACADEMY FACILITIES

Air Force

Academy

--Field House

--Arnold Hall

--Chapel

-Noon Formation

$1230-1330 \quad$ Lunch

Arnold Hall

$1330-1345$ Proceed to Fairchild Hall 


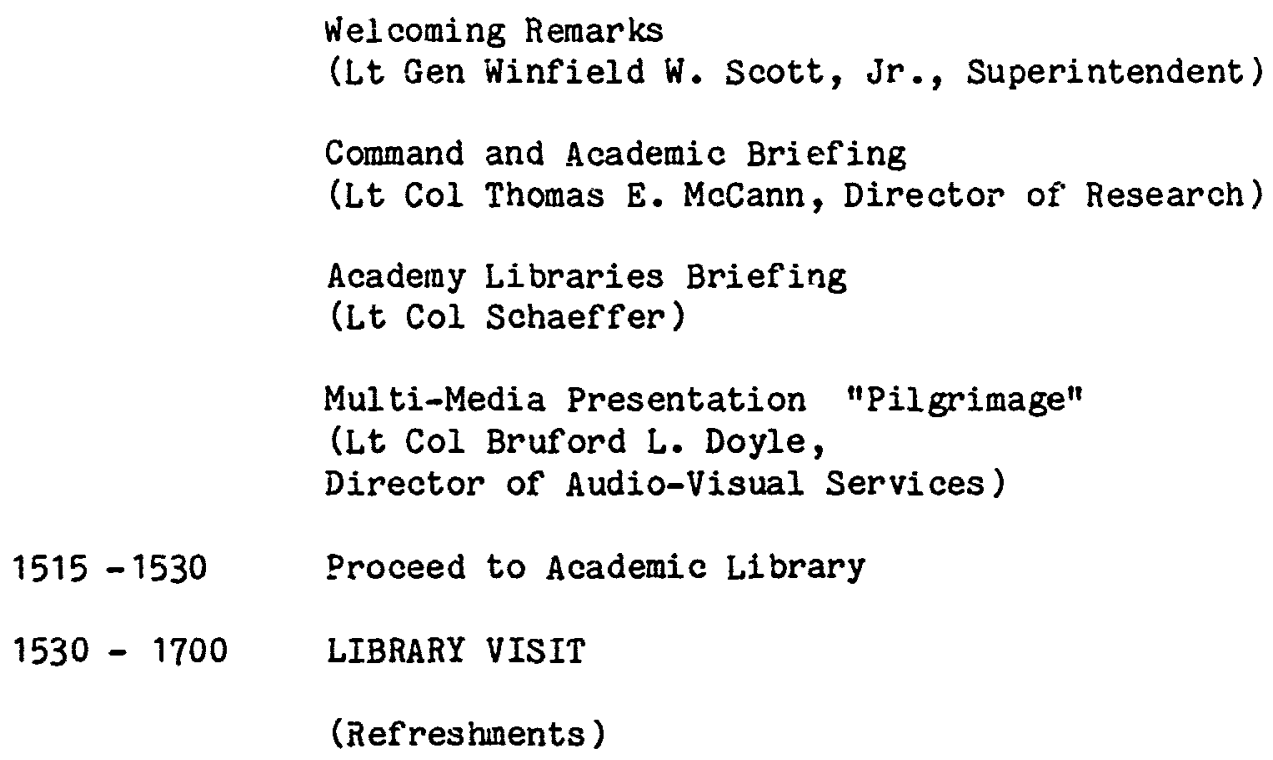
House

THOPSDEI ( 10 OCT)
$0630-0800$ Breakfast (On Your Own)
GENERAL SESSION
0800 - 0900 "Why and How We Win With People"
(Lt Col Pizzi)
Ballroom
$0900-0920$ BREAK (Coffee and Sweet Rolls)
Foyer
0920 - 1130 "Writing for Executives"
Ballroom
(Lt Col William E. McCarron,
Department of English)
$1145-1230 \quad$ Lunch
Ball room 


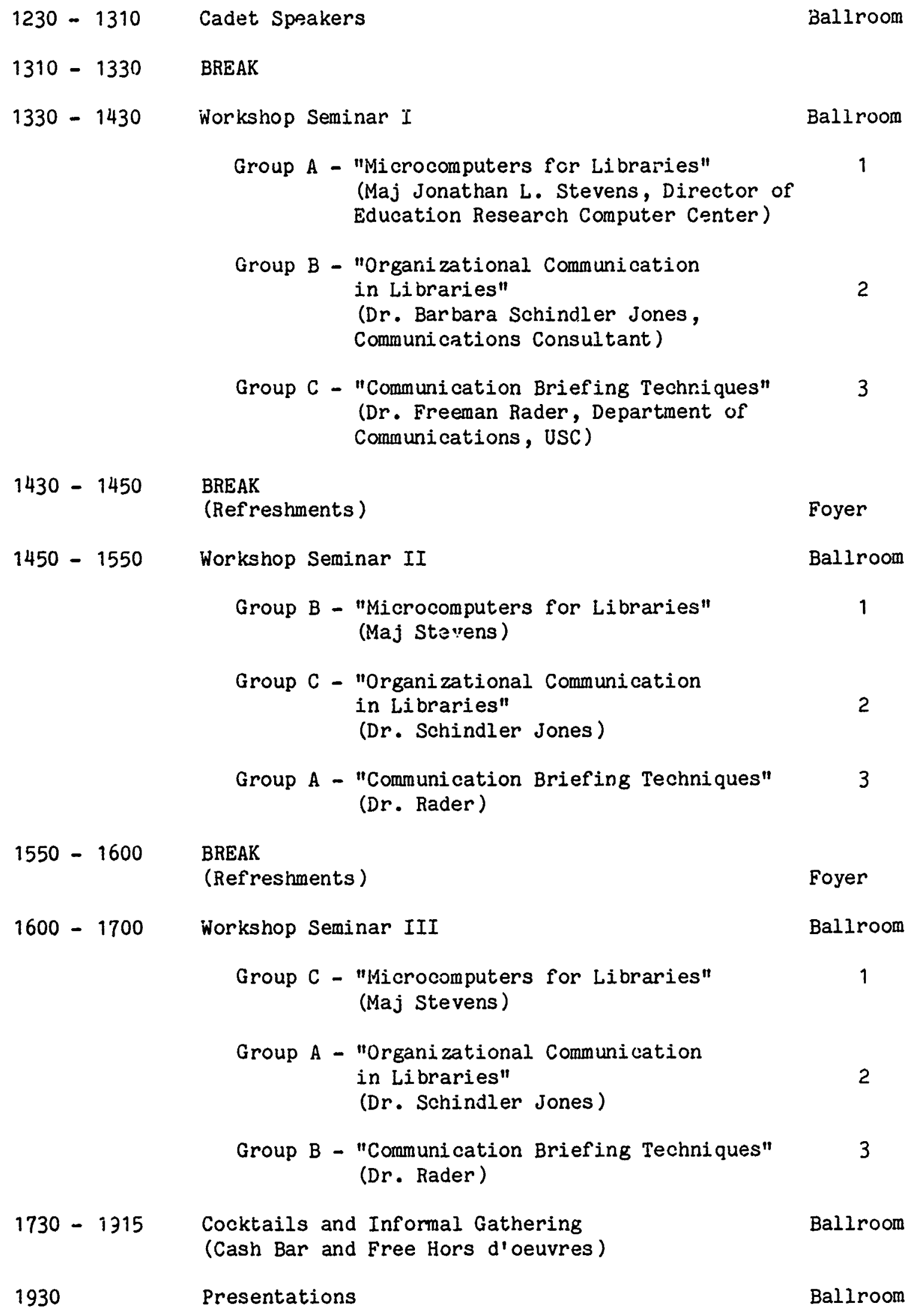


PRIDAI ( 11 OCT)

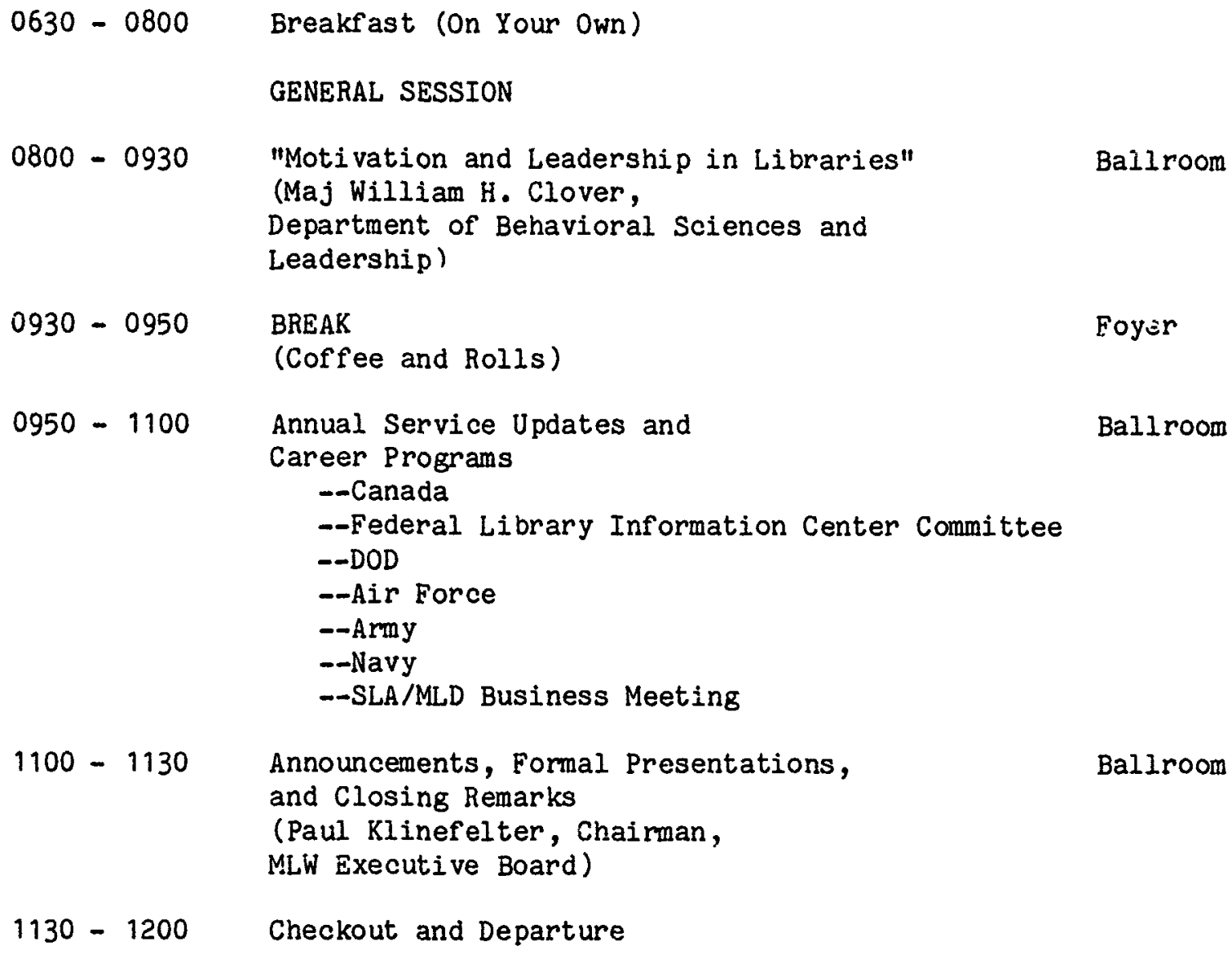

Ballroom

Ballroom

Ball room

AOF UTEDERSEHEU! 


\section{PIRST GEHBALL SESSTOI}

\section{Uel coning Renarks}

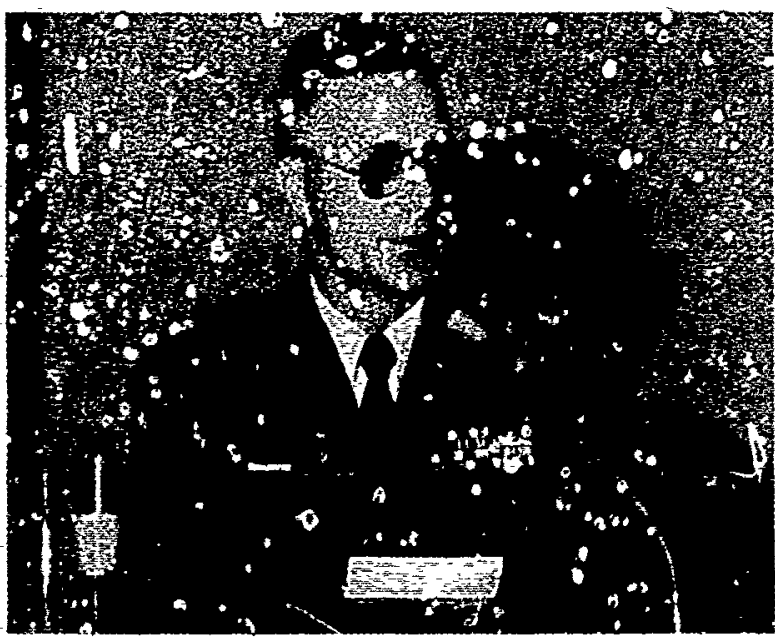

Lt Col Reiner H. Schaeffer

Director of Academy Libraries and

Associate Professor of German

United States Air Force Academy

Ph.D., Ohio State University

(Foreign Language Education)

M.P.A., University of Missouri

at Kansas City (Organizational

Behavior)

B.G.S., University of Nebraska at Omaha

(Business/Economics)

National Certificate, Government of

Switzerland (Business School)

Good morning, fellow librarians. The 29th Military Librarians' Workshop is now officiaily in session.

On behalf of the Superintendent, Lt Gen Winfield W. Scott, Jr., and the Dean of the Faculty, Brig Gen Ervin J. Rokke, I am extremely pleased to welcome you to Colorado Springs and the Urited States Air Force Academy. We at the ncademy are very happy to again host a Military Librarians' Workshop as we did in 1961 and 1975. Since the last workshop, our library facilities have changed corsiderably. You will now find a significant space improverent in our Library with the addition of some 45,000 square feet, all on one floor. Furthermore, since June 1985, we have an automated integrated library system. We are very excised to share our facilities and this system with you this afternoon.

Sinse my appointment as Director of Academy Libraries on 1 January 1982, I have been extremely impressed with the dedication, professional knowledge, service orientation, and the very high standards of the library staff. Although I consider myself what we may call "a people-oriented manager" (whatever that means), I am doubly sure today that we, as managers, do not do enough in the area of communication with our people, by working toward mutual commitment and understanding at all times. Thus, I hope that this workshop with the theme, "The Military Librarian As a Manager-We Win With People," has something to offer to all of us. In a way, each member of an organization is an integral part of the management process. As Donald Brown puts it: "Every person engaged in a given enterprise is called upon to perform a managerial function, or at least to perform a function that is directly serving the purpose of management." While there obviously is no one or best managerial approach--we have to do whatever works best for us in a given situation--I am sure that there is only one way to win in this complex management process, and that is "with people."

In addition to the foimal progran of this workshop, wo always learn the most, of course, by simply interacting and talking with one another about common areas of interest, problems, and mutual concerns. Our best teacher is experience and by sharing these managerial experiences, we learn. So let's have a meaningful and challenging workshop and return home with some new ideas on how to "win with people!" 


\title{
The Hifitary Librarian ls a Hanager
}

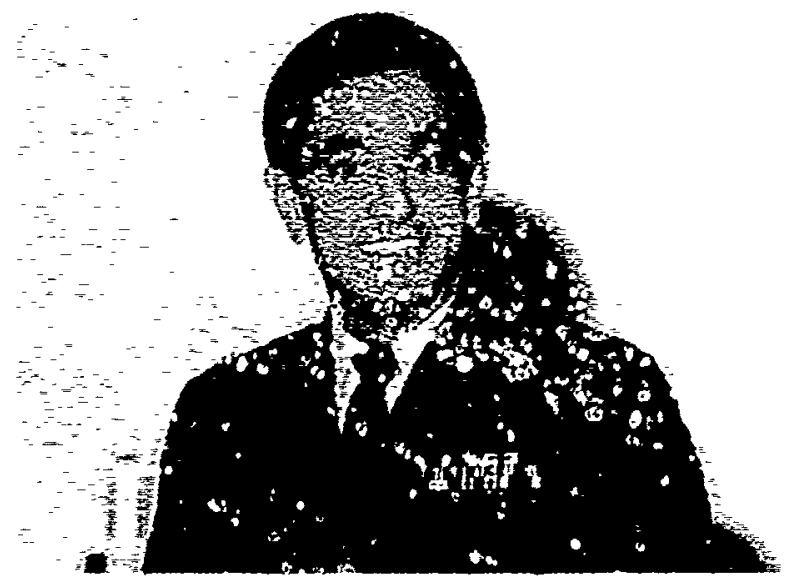

\author{
Lt Col Robert E. Pizzi \\ Deputy Head, Department of Management \\ Urited States Air Force Academy \\ Ph.D., University of Washington \\ (Business Policy) \\ M.S., University of hyoming (Business \\ Administration) \\ B.S., Duquesne University (Business \\ Administration)
}

Lt Col Pizzi told us thal the Management Equation is sinple: People + Resources + Money $=$ Mission Accomplishment. He explained that all of us are managers since we all deal with these three variables. We discussed our individual involvement with these resources as managers in the library.

We discussed how all three variables we:'e going down while our mission was gcing up. In other words, we had to do more with less. It's imperative that we become better managers. We need to get more from ourselves and the people who work for/with us.

Next we launched into a discussion of what we as individuals bring to the workplace. We decided that we set the tone at work. If we are positive then the work environment will be positive. Colonel pizzi led us in a discussion on personal awareness. The topics we covered were accepting, owning, thinking, growing, discovering, coping, motivating, centering, and being.

\section{ACCEPTING}

Accept yourself as a worthwhile, unique, and capable person.

OWNING

Own full responsibility for what you are, where you are, and the quality of life you have.

\section{THINKING}

Your attitude speaks louder than your words or your actions. Change the way you think about things, and you will change your life.

\section{GROWING}

Think results, not activities. Concentrate on things you can do something about. Learn from mistakes; forgive yourself for making mistakes and forget about tinem. 


\section{COPINE}

Stress, problems, and defeats are relative to the way vou epproash then. Develop a plan ror deiling successfilly with stres3, problems: and defeats. Recoginize the conscquences of successtul and unsuccesstul coping.

\section{DISCOVERING}

Get jnvolved--interact. Get perjodic feedback fron iriends, employees, peers, and bosses.

\section{MOTIVATING}

Think, talk, and ecr like a mutivited person. Sind ways to get positive reinforcement, suppori, ard encouragement.

\section{CENTESTIHG}

Establish worthwhile goais and values. Approach life as a "whole" person.

\section{BEING}

Learn to be good at your best self.

Colorel Pizzi left us with the thougint that we, not the speakers at this conference, are the experts. He encouraged us to visit and commuricate with each other during and after the conference. He said that tinere is no management probiem that at least one of us hasn't seen before, We are the experts!!!

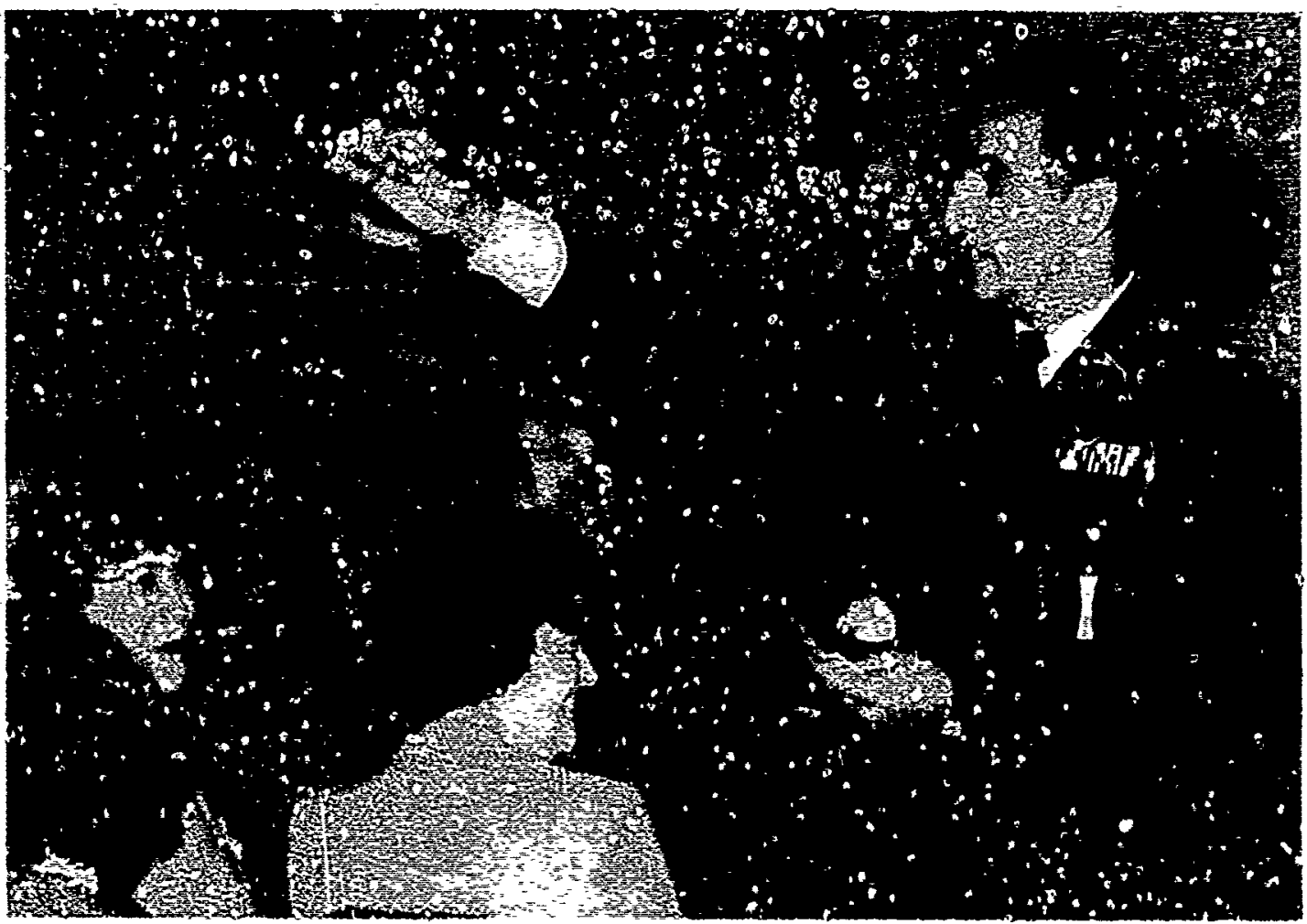

lt Col Pizzi in setionl 


\section{TOOE OF ACADEHY RACILITIES}

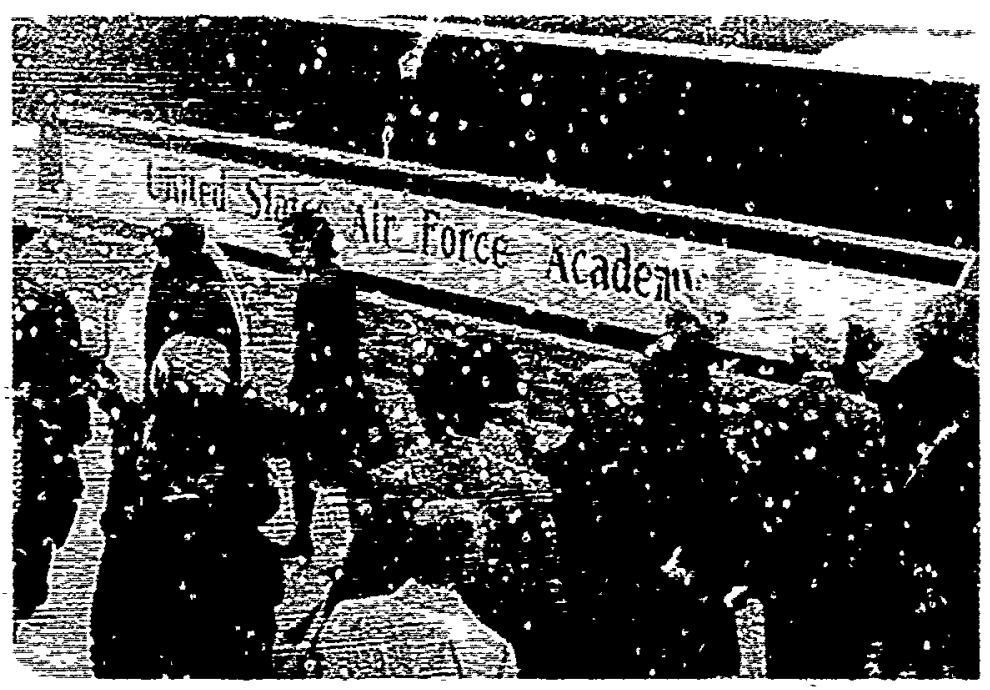

After the first general sessiun on 9 october, conference atterdees boarded buses for the trip to the fir Force Academy. During the remainder of the morning attendees toured some of the Academy facilities. We started at Arnold Hall, the cadet recreation center, where representatives from the Fuclic affairs office presented a snort briefing on the Academy, followed by a film on cacet life.

The rext stop on the four was the Field House which contains a full-siza nockey rirk, basketball court, arid indoor football fleld, as well as the most popular stop, the gift shop.

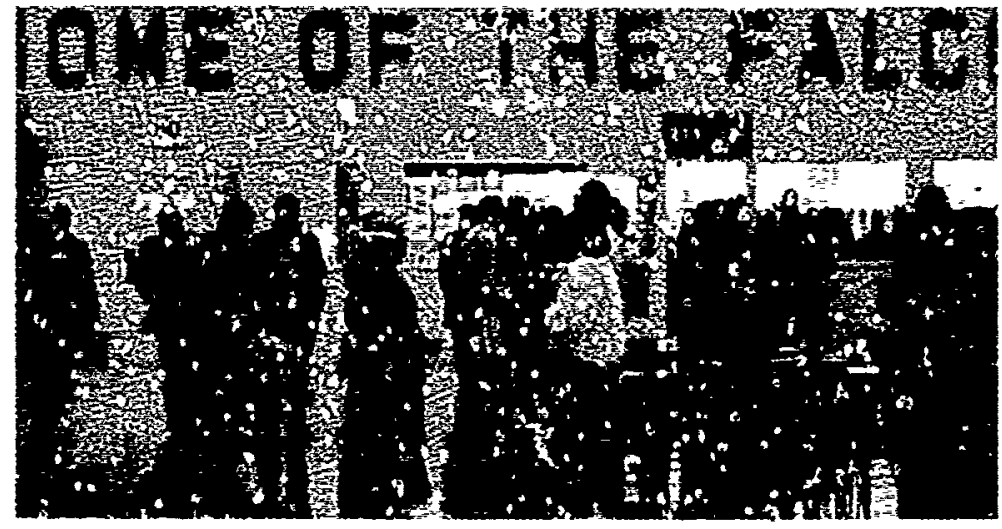

Our firal stop of the morning was a visit to the Cadet Chapel. Conferees walked through the Protestant, Catholj.e, and Jewish chapels and viewed the three-dimensionai re-creation of crrist, based on studjes by Academy faculty members of the Shroud of Turin. Due to unusually inclement weather, we were unable to view the cadet noon formation.

After a nice I unch in Arnold Hall, the group went to Fairchild Hall, the acadenic building, for an afternoon of briefings on the Academy and a tour of the Academic Library. The first speaker was Col John $T$. May, Vice Dean or the Faculty, who welcomed the conferees to the Academy on behalf of the Superintendent, Lt Gen Winfield W. Scott, Jr. and the Dean of Faculty, Brig Gen Ervin J. Rokke, who were both TDY during the conference.

Lt Col Thomas E. MCCann, Director of Research and Computer-Based Education, then presented a slide briefirig sumarizing the Academy's acalemic research, faculty composition, and cadet schedule. He stressed the Air Force Academy's prinary missions, which are "preparing young men and women to be the best second Lieutenants in the world; motivating them toward Air Force careers; and providing a strong educational foundation whicn will prepare them to take the reins of leadership in a world filled with social, ecoromic, and political challenges." 
The third presentation, on the Academy Library system, was given by Lt Col Reiner H. Schaeffer, Director of Academy Libraries. In this briefing he discussed the library system, consisting of the Academic, Community Center, Medical, Law, and Departmental/Office libraries; gave a brief history of the Academy libraries; presented an overview of the Academic Library's collection size and composition; elaborated on the Library's patron services with specific emphasis on the new integrated computer system and the Gimbel Aeronauiical Collection; and addressed the Academic Library's recent renovation project whicn added 45,000 square feet of usable floorspace, some 22,000 linear feet of shelfspace, and 500 additional seats for studying.

Following Col Schaeffer, Lt Col Bruford L. Doyle, Director of Audio-Visual Services, presented "Pilgrimage," a multimedia program commemorating the visit of noted author James Dickey to the Air Force Academy. Mr Dickey flew the P-61B reconnaissance plane in the Pacific theatre during World War II, and much of the presentation reflects his wartime experiences. The program was composed of readings of $\mathrm{Mr}$ Dickey's poetry as background to film and photographs from the Air Force Archives. The show uses nine slide projectors and two motion picture projectors coordinated by the Arion 828 multimedia computer system.

Following these presentations, the group moved to the Academic Library, and the conferees assembled in six small groups to make movement around the library easier.



An Academic Library staff member conducted each group of attendees to the various points of interest. After a few minutes in each of these areas, the conferees were given discretionary time to investigate the Academic Library on their own.

Primary points of interest in the Library were the Gimbel Aeronautical History Collection; Special Collections/Archives; the new Geac computer system; and the main floor of the library.

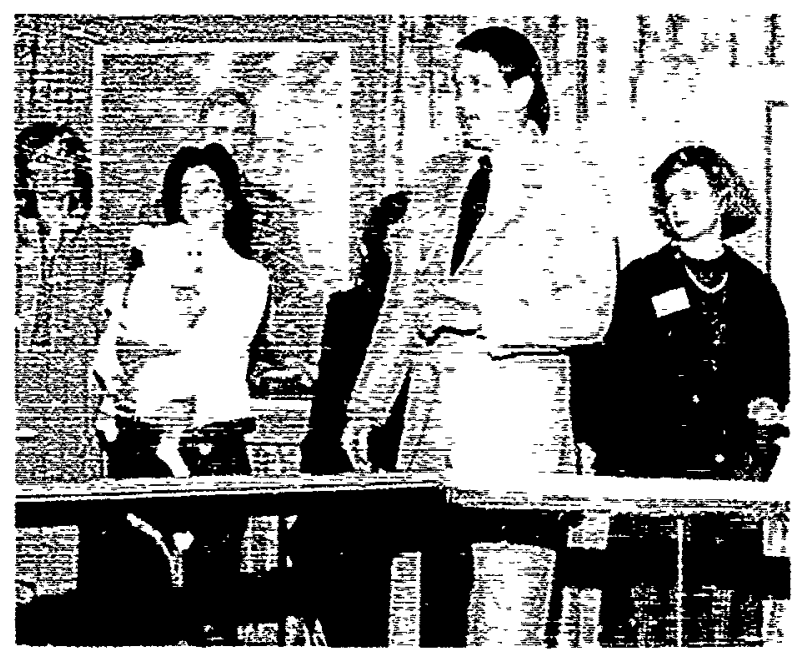

After the return trip to the Hilton Inn, many of the conferees joined us for a special evening at the Flying "W" Ranch. Everyone who werit seemed to thoroughly enjoy the steak dinner, rustic atmosphere, anc Western music,

(Additional information on the Air Force Academy is in Appendix II.) 
SECOID GEHBRAL SESSIOI

Uhy and Hor Ue Uin Uith People

Lt Col Robert E. Pizzi

Lt Colonel Pizzi led us in a discussion of how librarians can get more from their co-workers and subordinates. The first half of the discussion centered around the two attached hand-outs, "Organization Climate" and "How Healthy is Your Team?". Colonel Pizzi encouraged us to have our subordinates take the suryeys wi thout identifying themselves and then compare their perceptions with ours. We as managers must work to make our subordinates' goala and objectives congruent with ours and those of our organizations-ma real challenge.

Next, Colonel Pizzi discussed a technique for us to consider when dealing with subordinates. The technique, "Management by Objectives" (MBO), is merely a meeting between the superior and the subordinates for the purpose of setting goals for the subordinate. Using this technique guarantees that the manazer and the subordinate are working on the same wave length, i.e., they agree on what the subordinate should be working on, when, and what results are expected. There can be no surprises.

Our discussion revolved around these main points:

MBO is an Objective Setting Process.

This process permits a negotiation between superior and subordinates about what is important about the job we are doing, what is the best way to do it, and how we will measure results.

MBO is a Management Development Program.

This program is proactive rather than reactive. It emphasizes accomplishment and results. It is a participative managerent style.

MBO is an Approcch to Performance Aprraisal.

The method will aid in selecting who should get the best appraisals. There should be no surprises.

The MBO Process

The process consists of goal setting, action planning, self-control, and periodic reviews. You must determine who, what, where, and when to be most effective.

\section{Potential Problems}

Problems include management commitment, defining output, integrity of communications, linking performance to appraisals, time required for results, dependence on administration, and management mobility.

Colonel Pizzi again emphasized the fact that we were the experts, and we had the answers to management problems. He encouraged us to interact more as professional librarians. He challenged us to "make it happen." 

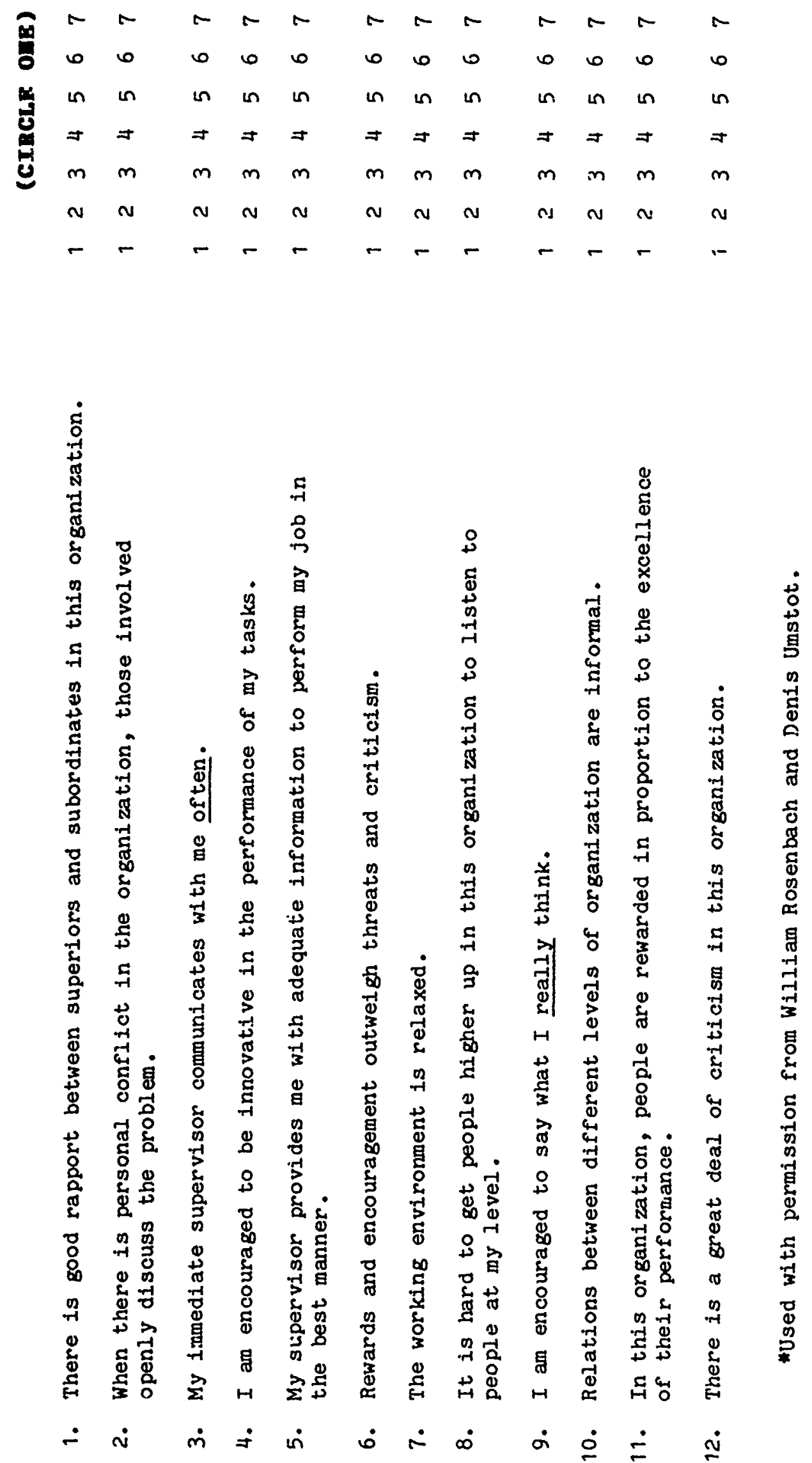


\section{HOH BEALTEI IS TOUR TBAH?}

Directions: Circle the number for esch item wilich best represents your team.

1. Low Productivity

2. Poorly Defined Goals

3. Low Trust Among Members

4. Conflicts And Problems Are Not Confronted

5. Closed And Ineffective Communications

6. Ineffective Meetings

7. Members Underutilized

8. Every Member For Hinself

9. Members Not Involved In Major Decisions

10. Disorganized

11. Low Morale

12. Member Responsibilities Not Clearly Defined

13. Members Do Not Know Where They Stand

14. Policies Are Rigid And Restrictive

15. Team Leader is Very Inaffective

\begin{tabular}{llllll}
1 & 2 & 3 & 4 & 5 & 6 \\
1 & 2 & 3 & 4 & 5 & 6 \\
\hline 1 & 2 & 3 & 4 & 5 & 6 \\
1 & 2 & 3 & 4 & 5 & 6
\end{tabular}

$12 \quad 3 \quad 4 \quad 5 \quad 6$

$123 \quad 4 \quad 5 \quad 6$

$123 \quad 4 \quad 5 \quad 6$

$12 \quad 3 \quad 4 \quad 5 \quad 6$

$\begin{array}{llllll}1 & 2 & 3 & 4 & 5 & 6\end{array}$

123456

$\begin{array}{lllll}12 & 2 & 4 & 5 & 6\end{array}$

$123 \quad 4 \quad 5 \quad 6$

123456

$123 \quad 4 \quad 5 \quad 6$

$123 \quad 4 \quad 5 \quad 6$
High Productivity

Well-Defined Goals

High Trust Among Members

Conflicts And Problems Are Confronted

Open And Effective Communications

Effective Meetings

Members Fully Utilized

Team Effort

Member:3 Irvolved In Major Decisions

Well-Organized

High Morale

Member Responsibilities Clearly Defined

Members Know Exactly Where They Stand

Policies Are Fiexible And Helpful

Tean Leader Is Very Effective

\section{SCORIIG}

Total Score (Add the Circled Numbers)

Team Health

Unhealthy Team

$(15-59)$

Heal thy Team

(60-90) 


\section{Uriting for Bxecutives}

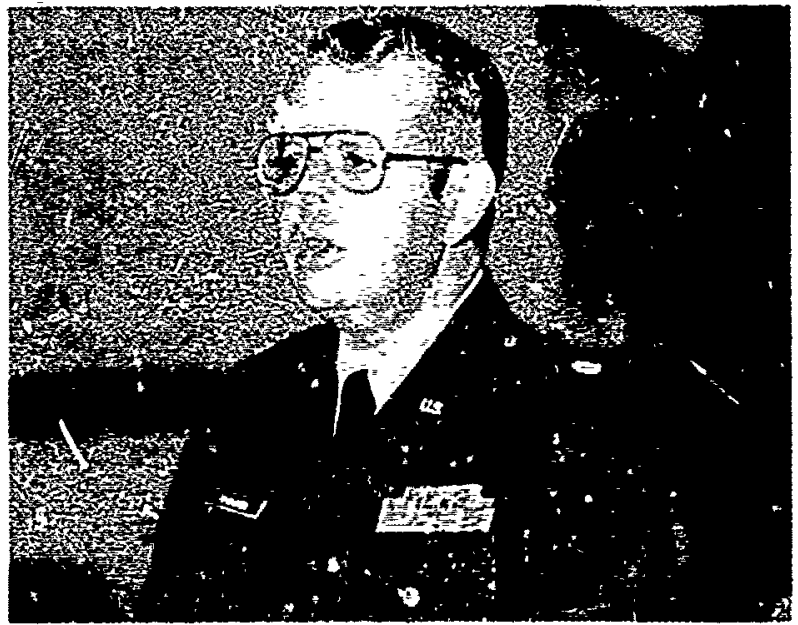

Lt Col William E. McCarron

Leputy Head, Department of English

United States Air Force Academy

Ph.D., University of New Mexico

(English)

M.A., Boston College (Fnglish)

B.A., Holy Cross (English)

Maj Jonathan R. Eller

Assistant Frofessor of English

United States Air Force Academy

Ph.D., Indiana University (English)

M.A., Indiana University (English)

B.S., United States Air Force Academ

B.A., University of Maryland

(English)

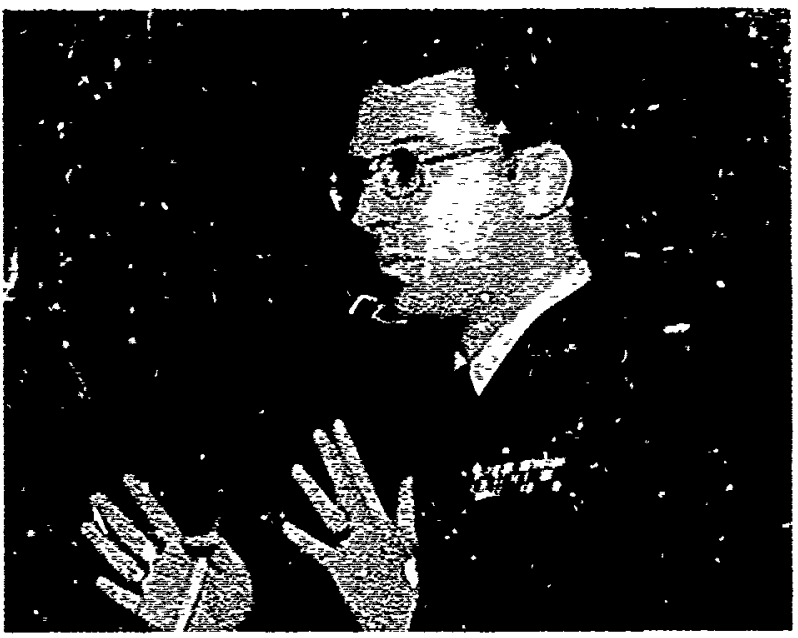

Lt Col McCarron and Maj Eller presented the Academy English Department's three-hour "Executive Writing Course" covering organized, spoken and concise writing. A brief sumary of this presentation follows:

Mos: 0 problems with organized writing begin with a failure on the writer's part to put the main point in the opening paragraph of a letter, memo, report, or operating instruction. A related problem is the failure to group ideas by subject matter. For example, in a memorandum addressing both building repairs and repair costs, the writer should first address all the repairs in one paragraph and then the costs in a separate paragraph.

Spoken writing is simply telephone conversation cleaned up--clear, everyday words without the "uh huhs" and "you knows." Writing can easily achieve a spoken quality when the writer uses personal pronouns, coniractions, simpler (not simplified) words and phrases, and occasional questions. For example, consider the leaden "bureaucratese" in this opening sentence from a NORAD test report: "An operationally effective and satisfactorily performing computer system is possible only if additional funding is made available to accommodate the requisite time for a more orderiy completion of the system development effort." Here's the re-write, emphasizing spoken English: "Will the new computer system work? Yes, but we'll have to spend more money to pay the contractor for the extra time he now needs." 
Concise writing means freeing drafts from excess words, eliminating smothered verbs, toning dcwn acronyms. Consider the following bulky sentence: "It is requested that the widest possible dissemination of this guidance be made to officials and individuals responsible for the slibmission of information in compliance with the Privacy Act." An easier, more concise version would read: "Please pass this guidance to all who release information under the Privacy Act."

The course concluded with some special applications of organized, spoken, concise writing: letters of recognition, civilian evaluations, and officer effectiveness reports. As writers, we can apply the guidelines outlined in the "Executive Writing Course" pamphlet (see Appendix III). As reviewers and signers of correspondence, we can encourage those working for us to use the organized, spoken style in all their writing. 


\section{Life at USAFA}

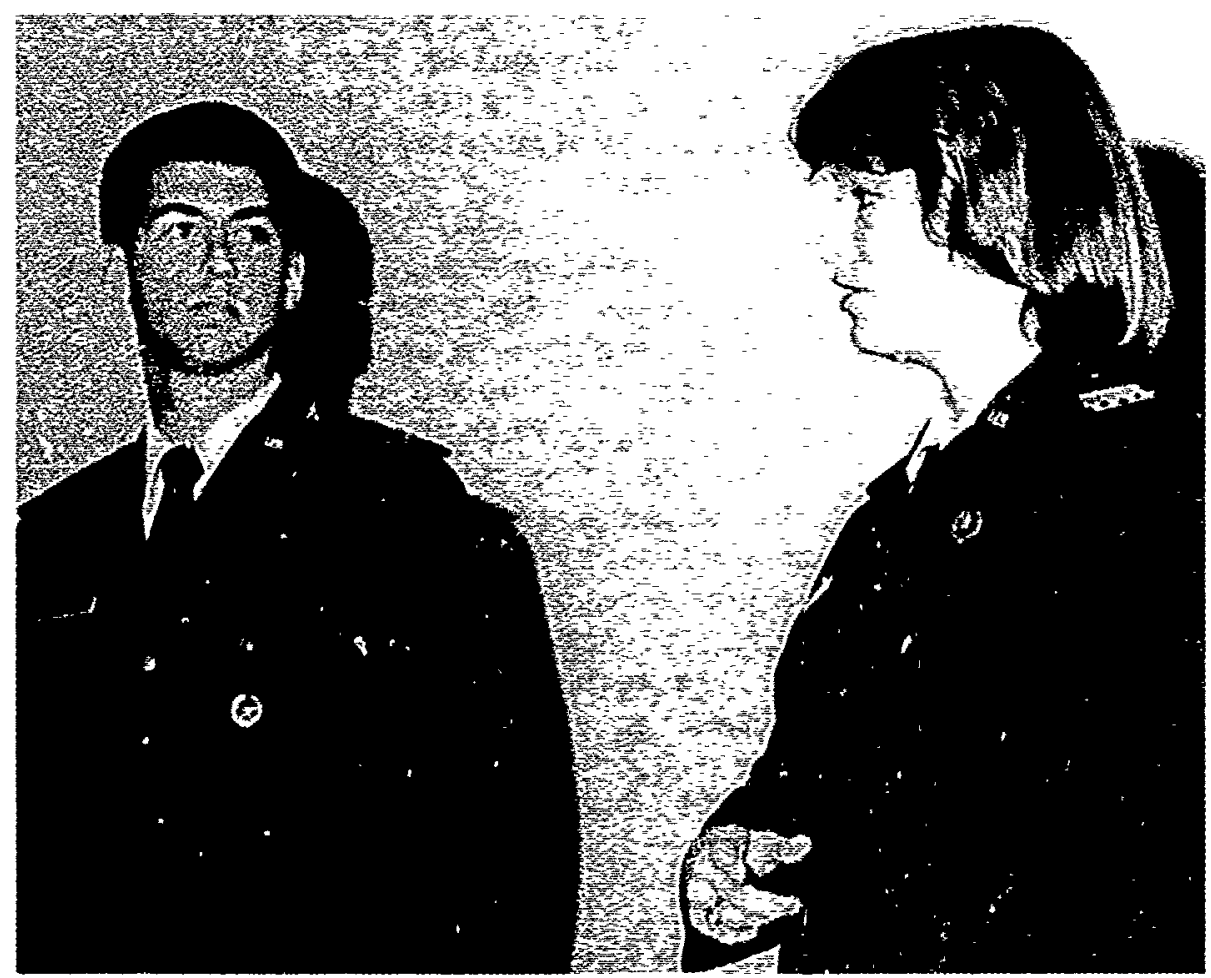

C IC Michael T. Forsyth, Cadet Squadron 2 and C IC Carolyn M. Reed, Cadet Squadron 4

Before lunch, conference attendees had the opportunity to interact with two Air Force Academy cadets, Class of 1985. Below is a summary of some of the cadets' comments and answers to questions from the audience.

Lt Col Schaerfer: We are very fortunate to have with us this afternoon two cadets from the Cadet Wing. We have exactly one-half ho: get these two young people back to the Academy because classes are calling. They will introduce themselves, briefly talk about their backgrounds, why they're here, and how much "fun " cadet life is. After that, we'll have some time to entertain questions fron the floor. We have no prepared questions like they do in most places, because I'd like you to ask what you tinink is interesting. Cadet First Class Carolyn Reed is a senior from Squadron 4 and $C 1 C$ Michael Forsyth is from Squadron 2.

I'm C1C Carolyn Reed and I'm from Balsam Lake, Wisconsir. The climate here doesn't seem that bad to me. It's rather mild compared to back home where it gets really cold. I can't really think back and remember just why I picked or decided to come to the Academy. I think it was more a lack of not knowing what the Academy was like that brought me here. I think I would have been scared off if I knew a whole lot about it. I remember thinking back, well, I'll never have to decide what $I$ want to wear to school in the morning. I looked at all the 
benefits, but I never really thought about if I want to be a pilot or if I want to work with people. I also liked the idea that I was going to get away from home; I lived in a real small community; I wanted to get out and do something. I wanted to meet people from all over. I've really found that there are a lot of really great people at the Academy, all the valedictorians in high school, all the athletes--a very outstanding group of people. Right now my plans after graduation are to go to pilot training if my eyes stay good enough, and I'd like to fly for as many years as they'll let me.

I'm C 1C Mike Forsyth. My hometown is 0skaloosa, Iowa. It's about 60 miles southeast of Des Moines. The original reason why I came to the Academy is that I wanted to get into space. I was interested in the space shuttle program; I wanted to do something with it. I thought I would come to the Academy and I would major in aeronautical engineering. When I got to the Academy, my interests changed, which happens to a lot of cadets. My interests changed from being an aeronautical engineer to becoming a managenent major. They give you a lot of engineering here. I want to work in systems acquisition and maybe work in Florida--still close to the space program, that's where my interests lie. The Academy's been a fun time for me. As cadets, we get a lot of chances to go around and see the real Air Force. It's been a real good experience. That's basically why I'm at the Academy. Questions?

Paul Klinefelter: Cadet Forsyth, tell us a little about your day; do you have enough time for all your activities?

Cadet Forsyth: An average day is pretty long. We get up at about 0600 in the morning; it goes until 2300. My academic load right now is 24 hours of credit. The average load is approximately 20 hours. I overloaded just to get some classes I really wanted. It's been a really busy time. As you progress in your cadet career, you don't feel the time pressure as much. You learn to deal with it a lot better. As a freshman, you don't have as big a class load, but you feel like you're running around more.

Question: Cadet Reed, what do you consider your chanses of getting into flight school?

Cadet Reed: My eyes right now are good enough, probably 100 percent. Anyone who goes to the Academy and is physically qualified is practically guaranteed a flight slot. So, even if my eyes are $20 / 100$, I'm guaranteed a position over someone who graduates from ROTC with perfect vision just because the Academy guarantees it.

Cadet Forsyth: As opposed to the other commissioning sources, cadets who graduate and are physically qualified are able to go to pilot training. For ROTC or Officers' Training School candidates, however, it's very competitive to get into flight school.

Question: This is a library question. The library is vastly different obviously from the high school and maybe public libraries. Tell us how you use the library in your career at the Air Force Academy.

Cadet Forsyth: The library is basically very easy to use. I use it mainly to go there and study. The lighting is a lot better than it is in the room. 
Cadet Reed: It's a lot quieter there. We live in the dorms and the people play their stereos. It's hard to study when they start goofing around. The research and everything is readily available and there are all kinds of people to help you if you want to look through government periodicals, NASA reports, whatever ycu're writing about. I'd say the primary use, too, is just a plaze to get away from the squadron and study, unless you're a history major and do research all the time.

Lt Col Schaeffer: Would you briefly talk about your squadron position? Maybe you can follow it up by explaining the superintendent's List, and what you do as squadron commander?

Cadet Reed: Right now, I'm a squadron commander. That means I have ,23 people in my squadron. I just love problems coming up and making a decision. It's imporiant to see if I can accomplish something for my squadron, get us a party together, do something, make sure everybody's working on academics. I've been told by a lot of officers that you don't usually get the chance to command until later in your officer career. So I think that as a cadet it's a great experience just to have that position.

Cadet. Forsych: I'm the squadron resources officer which is academics, logistics, and making sure supplies are in the squadron. I am also running Admin in the squadron. I have eight people working for me; there are four junior and four sophomores. Basically, what it is is that I just watch and make sure they take care of everything. Our jobs give us experience in what we will be doing out in the "real" Air Force. In my squadron, I have a squadron commander for whom I work and she has ultimate command of those 123 people. I. have eight people under me. Jobs last for a semesjer. They start from august, until December and then they rotate; everyone will get a new job in the spring.

Question: I have two questions. One, how are you chosen for these jobs in the squadron?

Cadet Reed: Each squadron has an officer associated with it who is called the Air officer Commanding and he/she usually selects a person.

Question: The other question $I$ have is when you go out to Air Force bases as third lieutenants in the summer, do you find they just pat you on the head and drag you around or do you find they actually give you a meaningful experience to help see what's going on?

Cadet Forsyth: That was the best program I went on; it's called "Operation Air Force." You really get to see an Air Force base. What goes on as far as whether you actually get to do something or whether you're just being led around depends on which base you go to. I've heard of $\mathrm{scme}$ bases where it isn't very well run. I've heard of other bases where they really put you to work. I went to Moody AFB, Georgia, and we had a really good time. We got to see what they did; we went flying a "ew times; and we got to stay with other people throughout our stay. It was a good experience! 
Question: What was your major personal adjustment when you came to the Academy?

Cadet Reed: I grew up in an all-girl family. My dad died when I was young, and $I$ had a sister and a mom. Moving into a dorm with 4,000 guys was a big change. It was real hard for me. I never had a brother. You don't lock your doors a lot $c$ f times. You have to get used to the lack of privacy and living with the guys.

Cadet Forsyth: The biggest adjustment $I$ had was adjusting to the time they demand of you especially during your freshman year and the lack of freedom. As a freshman you probably get out in a semester maybe twice, maybe three or four times, but you're there all the time on the weekends and everything. It seems really bad if you look at it in your own perspective. But if you look at it another way, if there are 1,500 other people going through the same thing you are, you know that you can make it.

Question: You all probably know someone who left after their freshman or sophmore year. Why did they leave?

Cadet Reed: I know a lot of people who left for a lot of reasuns. The major reason is that some people find the Academy's just not for them. They don't adjust to the military lifestyle. Others leave for religious reasons. One person in my squadron was really sharp--an excellent cadet. But, he didn't think the military coincided with his religious beliefs.

Cadet Forsyth: Some people I know came because of parental pressure. You probably heard that in your briefings yesterday. Some of these people come and they think, yes, I'm coming for myself, but once they get here and all the pressure is on them, they realize that it was their parents' pressure that convinced them to come here. During the first summer you're here, during basic cadet training, a lot of cadets want to get out, by saying, "Well, my Mom made me do it."

Question: I have a boy in the neighborhood who's in high school and he would like to go to the Air Force Academy when he graduates next year. What advice would you give that young man to prepare himself for an Academy career?

Cadet Forsyth: I would say that he should be involved in a lot of extra activities outside of school, especially in sports, because sports are a really big part of our education here. Also, he should take all the English, math, and science courses he can. Also, he should push himself as hard as he can in high school, and don't take it easy, because that's the way it's going to be once he gets to the Academy.

Cadet Reed: Contact someone who has been a fourthmclassman here, a freshman Some people don't realize what they're getting into basically. I would encourage him to find out as much about this place as he could before he came here.

Following the question/answer session, Mr. Klinefelter and Lt Col Schaeffer thanked Cadets Forsyth and Reed for the $r$ willingness to share their thoughts and experiences with the group. 



\section{Microcomputers in Librariea.}

Maj Jonathan L. Stevens

Director of Education and Research

Computer Center

Assistant Professor of Computer Science

United States Air Force Academy

M.S., University of Texas (Computer Science)

B.S., United State3 Air Force Academy (Computer Science)

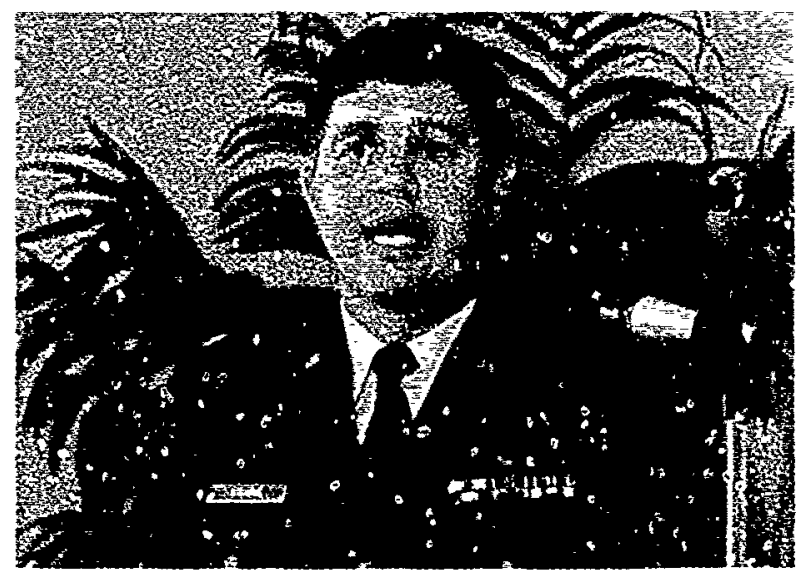

Without a doubt, microcompuiser technology will change our lives. It will change the way we do business, the library services we offer our users, and the way we solve problems. This paper will discuss ways a microcomputer can improve your library and improve the way you manage your library's resources.

\section{Why a Microcomputer?}

Microcomputers offer severai features that make them excellent computing toois. First, they are economical. The present Air Force/Navy microcmputer contract offers a Zenith Z-100 for under $\$ 2,000$. Other IBM PC conpatibles retail for under $\$ 2,000$. Many good printers cost iess thar, a good IBM typeuriter; and integrated software can be purchased for under \$100. Secondly, the microcomputer is exceptionally flexible. It can perfcrm a wide range of applications. Unlike a dedicated word processing system, a general microcomputer can support your budgeting, word processing, data management, and even deliver instructions. Even if you purcirase a microcomputer for a specifio purpose and later the need no longer exists, the raino can be used for arother purpose by purchasing a rew set of software. The micro can be easily moved from desk to desk or to public areas. It does not require special power or environment. Finally, the microcomputer and its sof tware are exceptionally easy to use. Hardware extensions, such as memory expansicns, can be instalied by the user. Millions of these systems have been sold for home and husiness use for people with no computer training. More importantiy, the nicrocomputer vendor has targeted his marketing to the individual consumer, not to the professional ADPE manager. The only way the vendor will be successtul is to make the sy"stim easy for the individual to use, and the vendors have been successful. The library staff will undoubtedly find the microcomputer to be economical, flexible, easy to move around and easy to use.

Another compelling reason for the library to consider using microconputer technology is the need to offer the library staff and the patron the opportunity to increase their computer literacy. Much has been said about microcmputers in our school systems today. They can be found at all levels of education. Several universities are requiring their freshmen to purchase one as ar: educatinnal tool, including the Air Force Academy starting in 1986. With such emphasis at all levels of our educational systern, it is reasonable to offer this technology in our libraries. In addition to providing general conputer literacy, microcomputers are also becoming an integral part of the information network in our society today. As information specialists, librarians really 
cannot afrora to be microconputer $312 i$ terate. Thus, having microcomfut 3 s in your library will aliow the staff and fatrors to becone more computer literate and take adyantage of the information explusion available today.

Given the positive features of che nicroconputer, this paper will now examine some practical applications--applications for tive library patron, technical applications supporting the libra'y's information and adininistrative processes, and finally applicatiors supporting the librariar as a manager. Sligsestions on how to get started are also orfered.

Library Applications--User Services

Public Access. For the library that can afford it, having microcomputers available for public access can provide a practical and well-used service. Users can take advantage of the micro's word processing capabilities. Basic computer-aided instruction (CAI) programs are plentiful and varied. For example, several good "how to type" computer programs can be used to teach complece novices how to type. This, along with other valuable skills, can be Learned by running the computer software with no instructor interaction at all. inother public access application that patrons can take advantage of is database management capabilities. Databases such as personal lists, bowling scores, or other sports statistics can be saved on the patron's own personal floppies and updated on the librery's micro. Finally, the satisfaction of learning computer programing, how to use a spreadshet, or explore different operating systems can be a great joy and service the library can offer. Even if the library cannot afford the capital investment of purchasing microcomputers, there are vendors who will provide coin-operated mioros such as the Micro Timesharing C.o. (20 Carmel Ave., P.0. Bü 4658, Salinas CA 93912, phone 408-424-0590'). Another company, Maxwell Library Sys'iems (2? G Great Rd., Suite 2i, Acton Mî 01720 , phone 617-263-2277) uses a type of credit card that wili allow users to have their microcomputer charges billed on the card rather than having to push coins into the machine. The Air Force Academy has been fortunate to have public access microcomputers for about one year. The experience bas been yery good. No serious vandalism or maintenance problems have occurred. All software is shecked out by the user from the circulation desk. Only occasionai problems with lost software have occurred. The five systems have had a 3 ot of use, primarily supporting word processing. A fairly extensive and diversified set of software is also available for check-out. For example, several copies of the more popular software packages can be checked out, thus allowing pastrons to try these packages before purchasing them for their department's personal use.

Local Databases

Small datatases are good candidates for mlcrocomputers, particularly those with short records. Information that the library updates frequently is al so a good candidate for beling put on a microcompliter. Some ideas are community bulletin coards, caiendars of event.s, small "how-to's" for using library services, and answers to frequently asked questions. Other ideas include putting special collection catalogs on the micro such as catalogs of musical scores or albums. Even the information on journal holdings could be put on the micro. The idea is to have a microcomputer located in a public and convenient place with an appropriate menu that the user could use to find the destred information. The micre provides a convenient tool for the library staff and a sirple way of updating the information being preserited. 


\section{Renote Datatase Searching}

The microcomputer can and will revolutionize the service of remote database and literature searches. The current scenario is a library with several searching services, most requiring specialized terminals or a unique terminal. that the service Jeases. If the library has three services and they want to provide the capability for f'ive people th use any service at one time, 15 terminals are needed. A microcomputer has the capability of "emulating" any of these specialized terminals. Most of the rajor searching services are now providing this emulator software to run on the more popular microconpiders. Given the same scenario, you can now use the same microcomputer you are performing other tasks with to perform the task of remote database searching by running the appropriate emulator. You would need less than 15 terininals since the same one micro could support any of the other three database searches.

In addition to terminal enulation, the micro can provide extended capabilities to the entire procesa of remote database searching. One such capability is log-on assistance. The phone number, log-on sequence, usercode and password, and any other preparatory commands can be stored in the micro's storage. Then, with a single command from the micro, the daiatase service can be phoned and logged-on. Another capability is the ability to upload and download ciata between the micro and the database service. Uploading means sending the service a string of information, much like the log-on information. Frequently used search commands can be saved and sent with a single command. A serits of search strategies can be developed and edited on the micro before logging-on to the datahase service. Money can be saved by doing this time-consuming activity while being "off-line" and not being charged connect time costs. Presently, when the result of the searcn is returred, it is printed on a printer associated with ihe specialized terminal. By having a mioro, the search results can be "downinaded" to the micro. With the results in the computer, they can be edited, taking out unnecessary data. The results can be printed for the user in a different order than they were received, or additional records can be added to the results. Finally, the resuits can be saved, merged with other inquiries, or added to your own database for losal searching from your own defined database.

An example of this uyload and download process being integrated with remote database searching is the "MEDIT" system at Texas A \& University. The University of Michigan and the National Agricuiture Library are also doing work in this area. Finaliy, system Devesopment Corporetion (2500 Colorado Ave., Santa Monica CA 90406, phone 213-820-4111) has a product called ORBIT Search-Master, This softizre, written for the Burroughs B-20, has the capability to perform auto log-on, off-line search strategy creation, upload the request, download the results of the senrch, and finally use a word processing package to edit the resuits.

The mcst aggressive microcomputer application is using the micro as a front-end processor to the remote database service. As such, the user is pronpted with questions as to what they are looking for. The micro sof tware then develop 3 the search command in the language recognized by the database service. A user would no longer need to know the database sear'ch language. The University of Illinois is presently doing research into this area having developed the TSW (The Searcher's Workbench). Soon the user will be able to desoribe what he/she wants, and the micro will generate a search command for the database service the user wants to use. 


\section{Library Applications--Technical Services}

The microcomputer cannot compete with the large, dedicated library computer systems such as OCLC, GEAC, Phase IV, etc. Of course, since these systems cost anywhere from $\$ 80,600$ to $\$ 500,000$, the microcomputer certainly can compete from the price standpoint. The micro can be used in small libraries or for small coliections. For instance, circulation services can be supported for libraries with 82,000 ciro records and 32,000 patrons by Futura Computer Productions ( 3028 Aquadale LH, Cincinnati OH 45211, phone 513-661-2266) for a cost of $\$ 30,000$. CTI Library Systems ( 1120 E. $300 \mathrm{~N}$, Provo UT 84061, phone 801-373-0344) offers a system consisting of an Apple II, capable of supporting 50,000 circ records and 10,000 patrons for $\$ 15,000$. Finally, one of the most affordable microcomputer software firms is Richmond Micro Software (Box 94088, Richmond, $B C$, Canada VGY 2A2, phone 604-596-8853). They offer a circulation package (software only) for $\$ 500$ that will support 65,000 circ records and 3,000 patrons. This software runs an Apple II computer system.

Acquisition control packages are also available. Most of these automate just part of the acquisition process such as bibliographic information or ordering information. These are also targeted at streamlining the paper work portion of acquisitions. One vendor, Innovative Interfaces, Inc. (2131 University Ave., \#334, Berkeley CA 94704, phone 415-540-0880) offers a turnkey system supporting acquisition for $\$ 46,500$. Richmond also offers a software package for the Apple II for $\$ 125$. Again, these systems primarily support the paper work process such as codes for vendors and addresses.

Few good packages exist for serials control. The biggest problem is the unpredictable nature of managing serials. Thus, publication frequency differences prevent complete automation. However, some packages are available for routing and binding control. For example, if your library is receiving a large number of serials that must be distributed to different organizations, the use of a microcomputer to handle labels and update the distribution list could be very helpful. Also, binding information can be kept on the micro to help with suspenses. Finally, other administrative processing supporting the technical needs of the library can be improved using a microcomputer. There are packages that will print catalog cards, help the users with menus, and fill-in-the-blank screens that output catalog cards with all information and data lined up properly.

In summary, there are many packages available supporting the technical needs of the library. Few of them can handle on-line card catalog services like the larger, more expensive systems; but they certainly can support circulation, acquisition, serials control and special administrative and word processing needs.

Library Applications for the Librarian

The microcomputer is an excellent manager's tool. The job of manager as a librarian lends itself to the flexibility and independence of a microcomputer. A librarian generally finds himself having a large amount of responsibility requiring a varied number of skills and generally has a small administrative support staff. Thus, to do a good job of both the administrative and the people-oriented tasks, the manager must be efficient and have access to good tools. Here are some ideas as to how a microcomputer on your desk can be used to support your job as a manager. 
Word Processing. The significant amount of paper work all managers have to do is greatly enhanced by using a micro. Performance reports are more professionally done and can be enhanced easier. Before the word processor, I remember the reaction I received when I gave my secretary a performance report to be reaccomplished for the fifth time due to some minor "improvements." The ability to send a "personal" letter to many special users is very expensive if each letter must be individually typed. Mailings are easy when you have a database and can put addresses on gum labels. Finally, depending on your typing skills, drafts for reports can be generated quicker with the word processing software on a micro. I am sold on the micro as a management tool, particularly for word processing. I believe it is not only more convenient but it allows us to really do our best work. I say this because whenever you do any writing, whether it is a performance report or a paper justifying mor a resources, you generally don't have any more than three opportunities to get it right--.the first and second drafts and the final. This is because of the significant expense to retype the entire report. With word processing, any minor improvement that enhances the work can be included. You have the opportunity to iteratively improve your work. This is absolutely necessary for any creativity or growth. So, for the opportunity to do your best work without being restricted because of administrative typing, put a microcomputer on your desk or your secretary's desk.

Fiscal Control. Most librarians have fiscal responsibility and must answer for the money budgeted and spent. The spreadsheet is a simple electronic ledger. It takes the work out of adding up the rows and columns and allows the manager more time to spend managing and asking those "what if" questions such as the impact of a cutback or what you would do with extra funds. Spreadsheets can be used for budgeting, keeping inventory of many things like supplies, different pots of money, employee time and any other activity that involves counting.

Maintenance of Files. Simple organization and maintenance information can be very time consuming. Most managers don't spend the time organizing and keeping track of all the information they have. Thus, they frequently are not able to find the information they need at the time they need it. Microcomputers can help with this process. Database managenent systems are popular and inexpensive. They can be easily updated, records added and deleted, and most importantly, reports generated. The same information can be output in the order most desired. The simple manner of being able to output information in many orders adds information to the original data. For example, most listings are output in alphabetical order. Outputting a list of patrons in order of home address zip code will give you the opportunity of analyzing groupings of your patrons. Larger libraries can consider doing the same thing for their employees. Keeping lists for mailing or membership lists are easy with the micro. Jpdating your own personnel rosters is easier, since the list can be listed in the new alpha order quickly. Even work schedules can be improved with the micro, particularly if you have part-time employees working many different shifts.

Project Management. Probably the most convenient and most-used micro application for managers is project management. How many times have you caught yourself asking "where did the summer go" or wonder on Friday what you did all week? The micro gives you the opportunity of having a "to-do" management package. This is really a simple database application that you can input your tasks to the program. These tasks are displayed and act as your "to-do" list that you are probably currently doing with scraps of paper on your desk. When a task is completed, you scratch the task off your "to do" list. The disadvantage 
of doing this on paper is that the information about the task just completed is lost. With the computer, the date the task was started, the date it was finished, and the task $i t s e l i$ is saved. Now, on Friday, you can see what you did all week because the list of completed tasks can be displayed. The sane is true for a project management program. The only difference is that you would have a data item that would identify the OPR (office of primary responsibility). Think of the help this information would give you at performance reporting time or when you have to justify your budget. Even reorganization time can be improved when you have the data on what offices accomplished what tasks. Any reader interested in such sof tware may find it easy to develop with any general purpose database managerent system (DBase II or Condor). I have developed a dedicated system written in Pascal that I would be glad to send to you. It will execute on a Z-100 microcomputer running Z-DOS or a VAX running VMS.

fetting Started. A lot of information has been presented including applications for user services such as public access micros; local and remote database searching; technical services such as circulation, acquisition support and serials management; and ways to use the micro to improve your performanse as a manager. With all of this motivation, how can the new nicrocomputer user get started? The first subject to tackle is the problem with technology intimidation. You may not be intimidated by the computer, out members of your staff or patrons may be. Why are they intimidated? One reason is because they don't know how to run computers or they don't know what to use them for. You certainly can combat that problem by having a good introductory course and specific goals and tasks to be met by the micro. Other folks are intimidated because they don't want to appear silly or because they don't know how to type. Again, this can be combatted by obtaining the softrare that helps the user develop his typing skills. A recognition and understanding of these intimidating factors can help ensure that the micrcomputers are productive and a welcome tool rather than a negative experience.

I feel the easiest way to become comfortable with a micro is to spend some time alone with the machine. There is little fear of being intimidated when there is no one around to feel silly in front of. It is really a joy discovering how to accomplish inany of the tasks you can do on the computer. Many computer stores allow customers to borrow systems and take them home for the weekend. Whatever means you have to get hold of a micro, spend some private time with it. Play some of the games. This helps get comfortable with the keyboard and learn basic system commands. Having spent some time with the system, the next step is to increase your knowledge and experience. Appendix III contains specific references to several information sources--conferences and literature, users' groups, bulletin boards, and use of public domain software. Each of these will be discussed briefly.

Conference/Literature. Most of today's library conferences have several sessions on microcomputers. Vendors are usually present who can demonstrate their products. Local organizations such as ACM and DPMA (Data Processors' Managenent Association) offer local seminars and short classes. These are inexpensive ways to get hands-on experience and excellent instruction. The number of computer-related periodicals is amazing. Certainly, a library should be able to get copies of these. Besides the more popular computer periodicals, business periodicals are excellent and probably a better source of information on microcomputers for the library's applications than the computer periodicals. 
Users' Groups. You will find a number of users' groups 1 isted in the Appendix. These are excellent sources of information, particularly those directly supporting the librar'y's applications. There may also be several local user:' groups in your community. These groups are usually dedicated to a particular type of system rather than a specific application, i.e., Apple II users' group or the IBM users' group. Information on these groups may be found in the community section of your local paper. The users' group meetings usually discuss software, how to get used computers, and can serve as a source for inexpensive consulting help. There are a number of real computer enthusiasts who probably know their machines betier than the sales personnel. A simple problem that may take you a long time to solve nay be something a member of the users' group can solve immediately.

Bulletin Boards. Although I do not feel this is a great means of Learning how to solve your microcomputer problems, the many bulletin boards available today have a lot of interesting information. There are many free bulletin boards frequently managed by a users' group. These you can put questions on or broadcast information that would have local interest. There are also several comercial bulletin boards whose popularity. will increase as micros continue to be purchased. These allow you to get to a vast amount of information just like the remote database literature searching. A strong selling point to try these bulletin boards is that it teaches you the basics of telecommunications with computiers. The process of using a modem, calling a remote computer and communicating with it gives you the experience you'll need for future electronic communications such as electronic mail, remote personal shopping and interactive television. Bulletin boards can be fun, enlightening, and very educational.

Public Domain Software. It is hard to believe, but a massive amount of excellent software is available and free for the asking. Any software project that is funded by the Federal government becomes public property or "public domain." There are commercial firms that collect these programs and for the small price of making the disk, anyone can get the software. The Attachment contains several sources that will send you a listing of thousands of programs that you can get for as little as $\$ 5$ a disk. This is the price for the disk, not for each program. The disk may contain over a hundred programs. The only disadvantage of the public domain software is that there is no software maintenance. If there are errors in the program, no one is available to $f i x$ them. So before you use a public domain program for anything other than your personal use, you must test it thoroughly.

As a final word on getting started, each Federal agency has a staff of qualified computer scientists whose mission is to support you. Use them; demand they help you. There are several Federal contracts for microcomputers that make it easy for you to use your 3400 Funds $(0 \& M)$ to purchase hardware, software and peripherals. There are base-level training classes on these small computers as well as many free Federal government-conducted classes that you can attend if you have TDY funds. There is no reason to venture out without consulting these fine people and giving them an opportunity to do their job. Good luck on your adventure. 


\section{References}

Issues of Small Computers in Libraries, Meckler Fublishing, Westport CT, Jan, May, Jun 85.

Woods, Lawrence A. and Nolan F. Pope, The Librarian's Guide to Microcomputer Technology and Application. White Plains, NY: Knowledge Industry Publications, Inc., 1983.

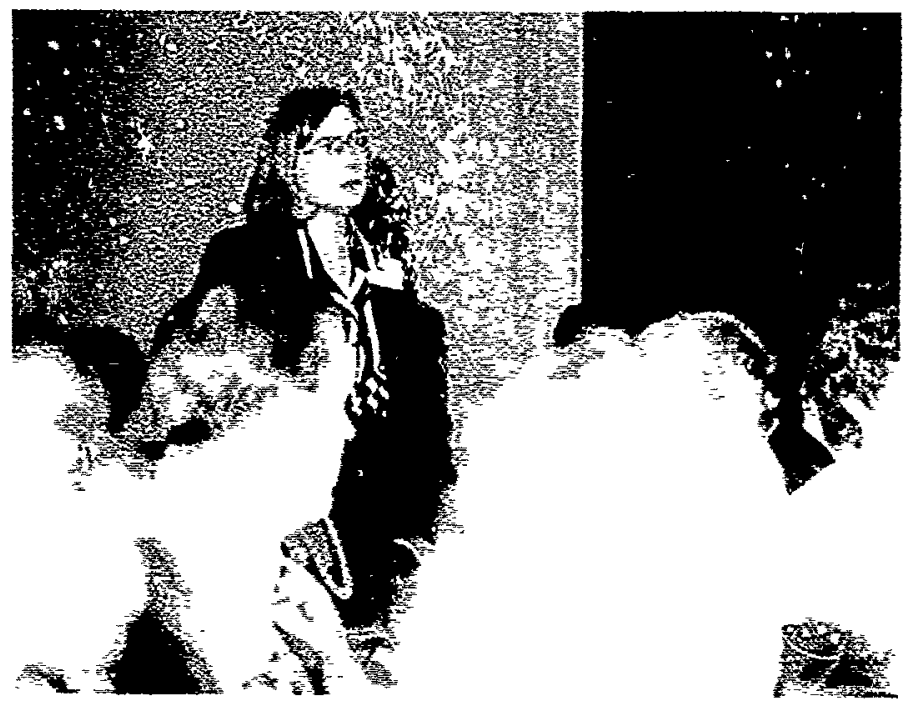

Questions for the speaker 


\section{Organizational Conqunication in Libraries}

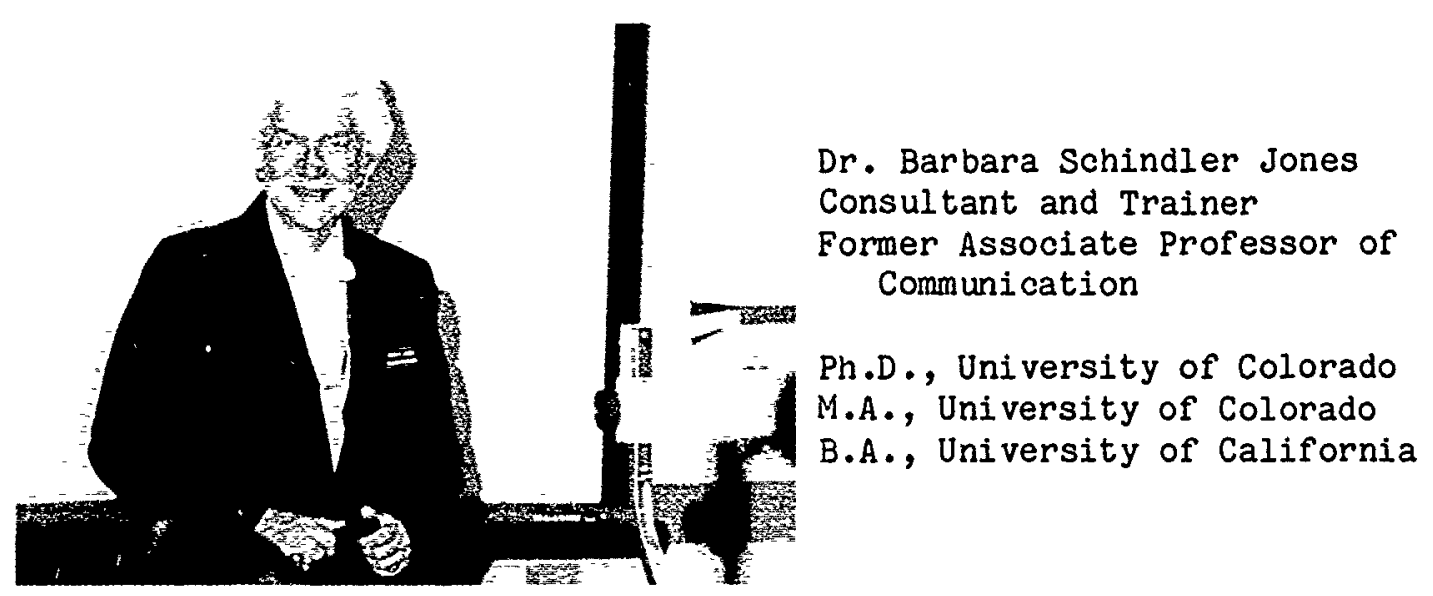

Introduction

Dr. Schindler Jones told us that most people problems can be traced in part or full to poor communication, a "breakdown" in communication, or no communication at all. All human interaction, including the work of our libraries, succeeds or fails as a direct function of our ability to communicate.

Part I: Interpersonal Communication

To share meanings, to be clear, to understand and be understood are goals of interpersonal communication. Listening, as the most important and the most difficult interpersonal skill, deserves greater analysis and effort to improve than most of us give it. With practice, we can learn how to really tune in to the patron, the colleague, and the boss with dramatic results.

Any situation in which there are opposing or blocked goals calls for negotiation. Are unclear or disputed roles causing interpersonal conflict? Are library units vying for the same scarce resources? Learning new negotiating strategies is the answer.

Part II: Small Group Communication

Meetings of all kinds are essential to effective libraries. Whether they are looked forward to or suffered through depends upon the group's understanding of crucial group forces and the complexities of leadership.

Although many of us have been taught to ignore or avoid conflict, as an unnecessary evil, ignoring or avoiding conflict shortchanges our libraries. Conflict is the best means of stimulating provocative ideas, creative solutions, and zestful exchanges. We can learn to welcome and successfully resolve those conflicts that prevent small group productivity.

Part III: Organizational Communication

Most library managers know thal no organizational structure works merely because it is well-designed and looks good on paper. They know form experience that the organizational system works well only if the people represented by the little boxes give their best efforts, have faith in the system, and understand how organizational communication wer' - 
Everyone in an organization needs information in order to make intelligent decisions, solve problems, and do their jobs. The library that provides essential communication where and when it is needed also provides the staff with the best environment for production and satisfaction.

Finally, organizational communication doesn't just happen; it needs to be planned for, designed, executed, and evaluated. The library manager who believes that communication will automatically "trickle down" to where it is needed, is abdicating a major managerial responsibility.

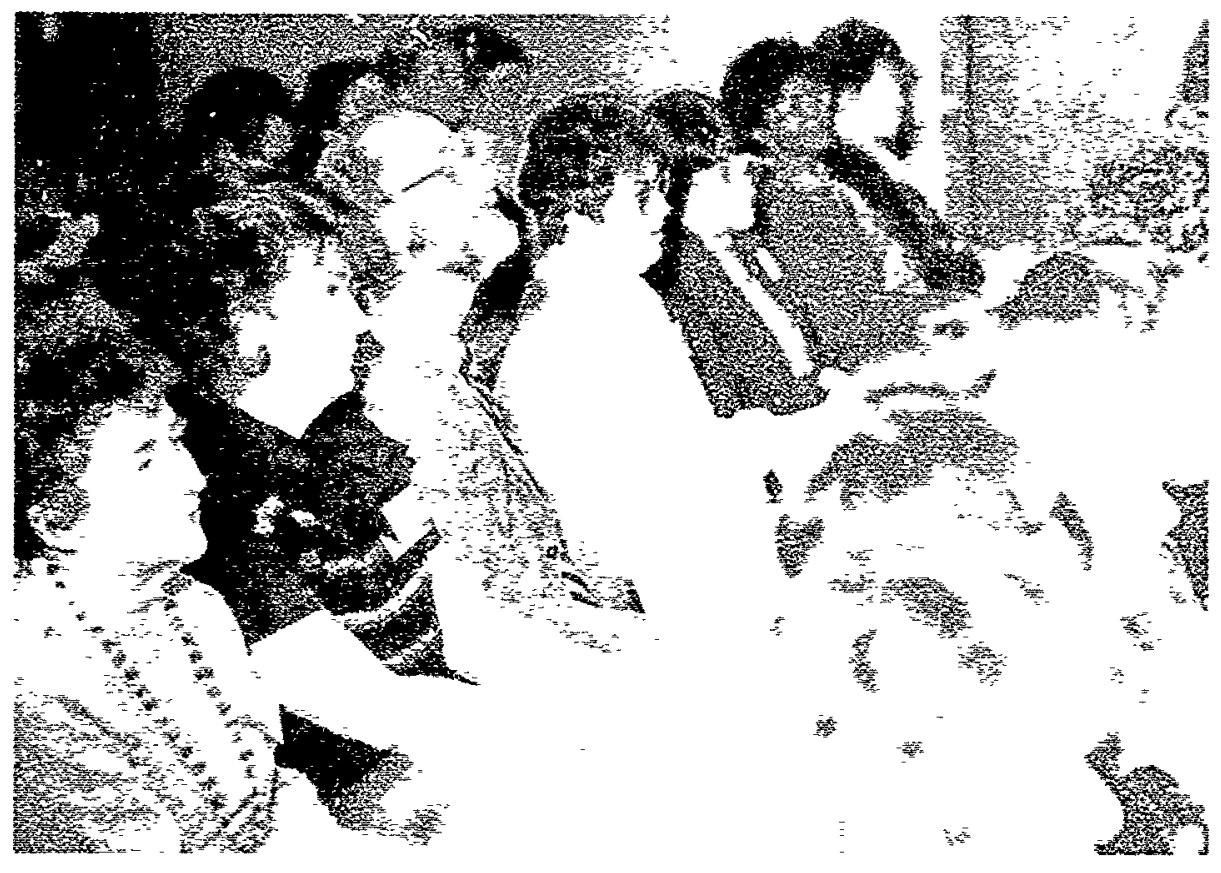

Very Interesting Presentations 


\section{Conunication Briefing Techniques}

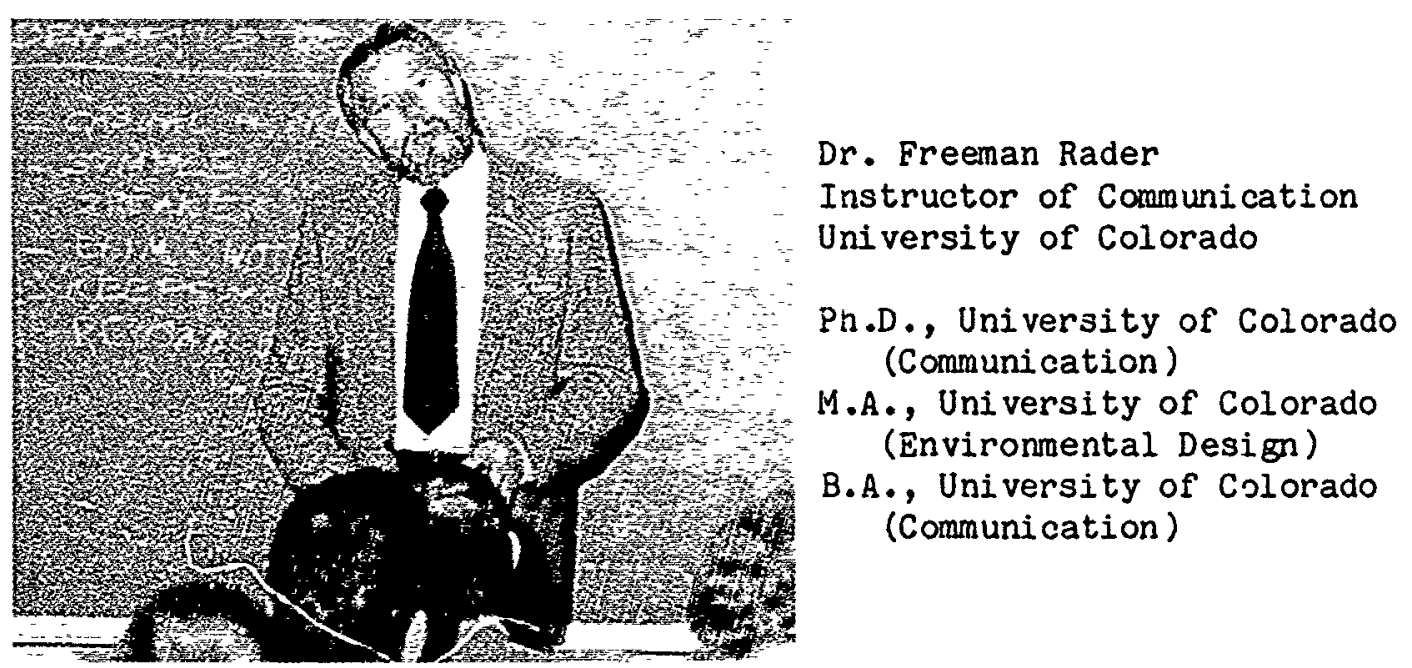

According to Dr. Rader, librarians, as keepers of the "storehouse of knowledge", have the ongoing task of familiarizing users and potential users with how to gain access to the storehouse. If librarians themselves cannot effectively present information of this nature, then an important "key" is missing. Not only will the vast resources of the library be underutilized, but the job of a librarian is made more difficult whenever he or she has to take time out to repeatedly help unfamiliar users find what they are looking for or begin to inform them of what is available. Therefore, librarians need to know how to communicate effectively and present information in person to groups of potential users not only as a key to "unlocking the storehouse of knowledge" for others, but also as a key to making their own jobs much easier.

The workshop on Communication Briefing Techniques provided librarians with a simple formula or "recipe" for how to prepare quick and easy presentations by using the right "utensils", "ingredients" and "procedures". Techniques were presented which enable persons to (1) organize thoughts and information effectively, (2) present information easily without the need for notes and memorization, and (3) make the information relevant and retainable by the audience. By following the techniques taught, not only is such of the anxiety eliminated from having to prepare any type of presentation, but the whole process actually can become one which is easy and. arding and guaranteed to produce effective results. 
"Recipe" For Preparing a Quick and Easy Library Presentation

UTENSILS NEEDED

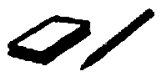

$3^{\prime \prime} \times 5^{\prime \prime}$

NOTE PAD

\& PENCIL

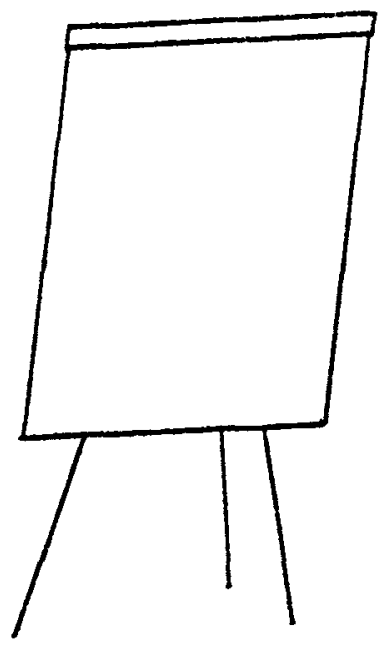

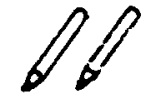

FELT TIP

MARKERS

(Water

based)

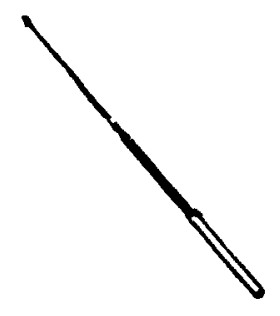

POINTER

PAPER CHART

INGREDIENTS

INTRODUCTION

BODY

CONCLUSION

(name \& topic)

- RELEVANCE

- "CATEGORIES" OF INFO

- SUMMARY

- PURPOSE

- MAIN POINTS

- PURPOSE

- PREVIEW

- SUPPORTING INEO

- RELEVANCE

\section{PROCESS}

Step 1: SITUATION ANALYSIS (audience, facilities, occasion)

Step 2: ATTITUDE BUILDUP (psych yourself up)

Step 3: TOPIC AND FOCUS SELECTION

Step 4: SELECTING APPROPRIATE "CATEGORIES OF INFCRMATION"

Step 5: INTROSPECTION/RESEARCH

Step 6: "FILL IN" OF BODY, INTRO, AND CONCLUSION

Step 7: PREPARATION OF VISUAL AIDS

Step 8: PRACTICE (at least 5 times)

Step 9: GO EARLY AND SIT UP FRONT 


\section{THIRD GBHERAL SESSTOY}

\section{Motivation and Leadership in Libraries}

Major Williath $\mathrm{H}$. Clover

Tenure Associate Erofessor of

Behavioral Sciences and Leadership

Ph.D., Bowling Green State

iniversity (Industrial Psychology)

M.A., St. Mary's University

(Psychology)

B.A., Southern Illinois

Uni versity (Psychology)

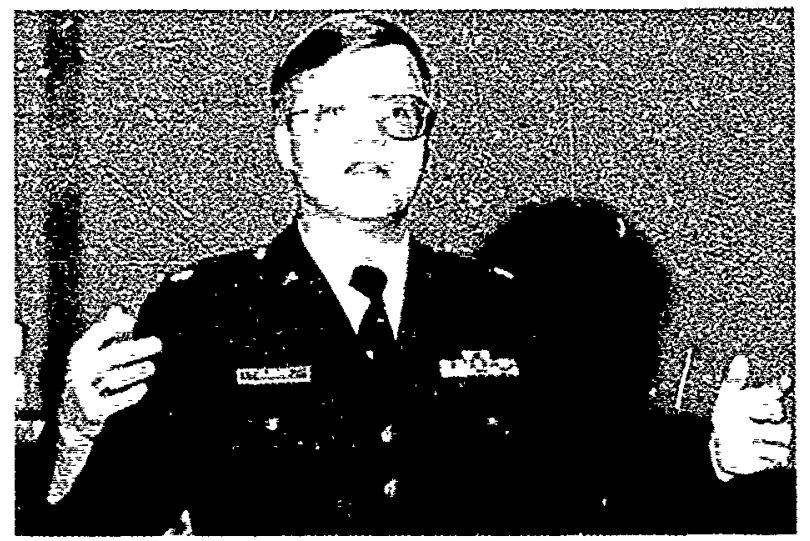

Aristotle is reported to have said (Harris, 1982) that the truth is like a barn door. If you aim at it you will hit it, but you will only hit part of it. The purpose of these remarks is to suggest zome truth about the issue of leadership. I don't pretend to have all the answers, but I do think the theories I will discuss have hit the "barn door" in one or more spots. My consents are intended to accomplish several goals. First, I would like to clarify the meaning of transformational and transactional leadership. Second, I would like to convince all of the readers that leadership of both sorts has the potential of taking place in every military library in the world. Third, I would like to note a few examples of the use of language as a factor among transformational leaders.

The idea of transformational vs. transactional leadership came from James MacGregor Burns in his book, Leadership (1978). Obviously, there were earlier intellectual roots. MacGregor Burns talks about charisma and he talks about the ability of transformational leaders to elevate a person's "need" level which directly ties to Abraham Maslow and his concept of a hierarchy of psychological needs ranging from physiological needs to self-actualization. MacGregor Burns said that transformational leaders were those individuals who motivated followers toward transcendental goals. They aroused subordinates to strive to fulfill higher level goals that went beyond self interest. As an example, you might thinx of John F. rennedy's "ask not what your country can do for you, but ask what you can do for your country."

On the other hand, Burns says transactional "leaders approach followers with an eye to exchanging one thing for another: jobs for votes, or subsidies for campaign contributions. Such transactions comprise the bulk of the relationships among leaders and followers, especially in groups, legislatures and parties" (Burns, p.4). They motivate followers by exchanging with them rewards for services rendered. Perhaps the classic example on the political scene in recent years has been Lyndon Johnson. it has been said that no one could "work the system" betier than Johnson when it same to makir.g things happen in Congress. It is important that we don't take a totally dim view of transactional leadership. In a utilitarian society like ours, it is no small sirill to be able to accomplish these types of transactions. It is also no small skill to know and understand what subordinates or followers want in any given transaction. Transactional leaders must possess a great deal of insight into people and situations. 
MacGregor Burns' work creates a dilemma. On the positive side, he gives a new way to conceptualize leadership. On the negative side, all of his examples are of world class political leaders. Implicitly, therefore, MacGregor Burns' work seems to rule out anyone below the level of a world-class leader. Fortunately for us, Bernard Bass took exception to that idea. In his book, Leadership and Performance Beyond Expectations (1985), he accomplishes two significant feats. First, he operationalizes MacGregor Burns' key concepts of transformational and transactional leadership. Second, and equally impirtant, he presents a convincing case from experimental data that we all can be transformational and transactional leaders.

In operationalizing the terms "transformational leadersip" and "transactional leadership", Bass breaks both of these terms into measurable components. With regard to transactional leadership, he says that it consists of three sub-approaches to leadership. These are contingent reward (a type of carrot and stick approach), management by exception (probably best summed up by the phrase "if it ain't broke, don't $f i x$ it), and laissez faire (a laid back approach exemplified by Mad magazine's "What, me worry?"). These three approaches summarize the transactional leadership style for Bass. Transformational leaders, on the other hand, seem to possess four characteristics. These are the abilities to appear charismatic, the ability to inspire, the ability to provide individualized consideration for subordinates, and the ability to intellectually stimuiate subordinates.

The second point that Bass makes is that transformational leadership can occur at the small-group level and not just at the world-class level. This is a very important point. It asserts that individuals don't have to be world-class leaders to have a transformational impact on other people. Most leadership models developed today seem to concentrate on transactional types of leadership situations as opposed to transformational ones. This is unfortunate. It is important that we think aoout leadership in global terms, so that we don't arbitrarily rule out sionificant areas of a leader's effect. Since human beings are both rational and emotional, it may be useful to think of transactional leadership as touching the rational side of humans a dd transformational leadership touching the emotional side. When we review leadership models we see that most of them have a bent toward rational approaches. However, Bass points out that these models can't account for all the behaviors exhibited by followers. Therefore, the transformational, or emotional, effects should be considered also.

My conceptualization begins with a rational model of leadership and then tries to show key points in the rational model where transformational leaders have an impact. The rational model that I like is Victor Vroom's expectancy theory. Expectancy theory offers a very systematic approach to thinking about people at work. It is a very rational model, and, in essence, allows you to understand the transactions that must take place if you want to get people to work hard for you. In general, expectancy theory asks you to assess four questions. They are:

a. What are the outcomes people expect to get by working for you or your organization? Realize there are both intrinsic (sense of acconplishment, feeling of job well done, etc.) and extrinsic (money, promotion, etc.) outcomes.

b. How much do people value these outcornes or how important are these outcomes to them? 
c. Do people believe that theip performance will lead to these outcomes? That is, what is the probability of belief that I will get a sense of satisfaction if I do this task or any task? What is the probability that I will get promoted if I work hard?

d. What is the probability that if I put out the effort it will actually lead to high performance? Note that questions "c" and "d" are very different. In essence, question "c" asks about the "system" which you control (i.e., your library) and the other (question "d") asks about the self or an individual's self-esteem (Lawler, 1973).

These four questions all ow you to construct a very rational motivational picture of your organization. They are very valuable questions to ask. For example, they may cause you to find out that people don't value the things that the organization offers as a reward. They may reveal that people believe that there is a very low probability that high performance will lead to the outcomes they value. Upon further analysis you may find that the cause of these beliefs resides in organizational practices or policies. You can fix these things and, therefore, have an impact on the motivational level of the overall organization.

I think that expectancy theory and its many variants (see House, 1971) can provide very helpful guidance for enhancing your understanding of your library staff. On the other hand, it doesn't provide all of the answers. In particular, as I try to understand both MacGregor Burns' transformational leadership at the political level and Bernard Bass's re-conceptualization of it at the small-unit level, I find that transformational leadership helps me understand how I can "flesh out" expectancy theory to a greater degree. That is, the concept of transformational leadership helps me understand questions "a" and "d" in the expectancy theory formulation. What causes people to believe that their effort will lead to success? What causes people to "value" or find an outcome important to then. Here, I believe the concept of transformational leadership is very helpful.

David MoClelland (1984) cites research by his student David Winter which indicates that people literally felt empowered after listening to a speech by John F. Kennedy. Additionally, Bennis \& Nanus (1985) say that visionary leaders empower others to translate intention jinto reality and sustain it. Research like this supports James MacGregor Burns' assertion that transformational leaders elevate the psychological-need level of subordinates. Yet, the important point of this paper is that not only world-class leaders have this transformational impact on other people. Helen Hayes (quoted in Readers Digest, March 1985, p.131) once said, "We relish news of our heroes, forgetting that we are extraordinary to somebody too." When I ask people to think about questions like the following (from Bernard Bass):

a. Think about someone who has caused you to do more than you expected you would do.

b. Think about someone who has caused you to do more than you expected you could do.

c. Think about someone who has given you reasons to change the way you think about problems.

I inevitably listen to stories of teachers we had in school, librarians we used to work for, counselors "who took us under their wing," parents who expected our 
best effort but who still loved us when we failed, etc. In gereral, the responses I get never include a world-class leader. $0 \mathrm{n}$, as one young inigh school student told me, "Sir, my list is filled with just everyday people." That is the point in a nutshell. Everyday, supervisors and heads of our libraries throughout the world are finding ways to be extraordinarily important to someone. To be sure, it is not easy. In general, if you want to be a leader you must think about what the term means. I have tried to say that Maciregor Burns' and Bernard Bass's treatment of leadership shows how we can be boch transactional and transformational.

Finally, I would like to say that transformational leadership (changing someone's self-esteem or what they value or find important) can be aided by your use of language. First, you musi have the big picturs and, second, you must be always looking for the opportunity to communicate it.

Let me end with two stories. Both stories, I think, exemplify the power of language to have a timely, and possible transformational, impact on subordinates, followers, colleagues. The first comes from Readers Digest (date unknown):

As a fellow policeman and $I$ were eating lunch in a cafe, we heard a "Jinan nearby say loudly, "Jimmie, if you don't eat all your peas, I'll have those policemen come orer and talk to you." My friend promptly walked over to the five-yearold who was being scolded. "Jimmie," he said, just as loudly, "I'm six-foot-two and weigh 200 pounds. And I never ate a pea in my life."

As we left, the other patrons were laughing, Jimrie's mother was absolutely silent, and a smiling Jimmie was no longer af raid of policemen.

Contributed by Donald A. Norenberg

The second story comes from a speech given at a junior high school dinner to honor a principal who was leaving after many years of service. The speech was given by Mr. Ross MacAskill, Assistant Principal at the Air Acadeny Junior High.

Thanks for giving us tonight, Dom (the departing principal).

But before we say goodbye, I would also ask that we take a glimpse at our future... Next year will not be easy. Not only do we have our regular task, which is so very difficult, but we are called upon to prepare for middle school, and choose a school at which to teach the following year. This will involve making new friends and saying goodbye to old colleagues and a way of life in which we have grown confident (or at least zs confident as one can get in junior high school). Next year will bring change, uncertainty, and anxiety.

But we'll do fine next year, Dom--because of you. Because we knoz that people who work hard, who iike kids, who like teaching, and who respect and love each ot ter, cannot fail. And that's what your gjft of the future will mean. 
A teacher cannot content with teaching knowledge of the present. it or she wust teach sith the hope that it will make a difference in the futcire, when he or she is no longer there. What you have giveli tis will sustain us. We shall succeed next year and beycnd. We won't do it for you, but because you have taught us how important it is to encuurage each other, to support each other, to care for each other.

Some of us will work with you again, Dow, but whether or not we do, your gifts have been given and they will last for a.s long as we do what we do.

These trio examoles show how language can be used to be transformational. First, the polizeran's story tells us that we have to have "the big picture." We have to have a vision of what vee are about. Second, we have to be ready when the opcortunity exists. Pasteur is quoted as saying that "chance favors the prepared ilind." This doesn't just apply to scientists. It implies that we all have to know our business and know it well. Third, we have to seize opportunities to exprese our visior of what our organization means or how it fits, or expres: where it is going with leadership. The policeman wasn't just being funny, he was communicating a much larger perspective concerning societ.y's view of law enforcenent officials. He wasn't the chief of police but the Chief of Police could not have communicated the message better.

The second story reminds me of a comment from Harry Levinson (1975) when he says (slightly paraphrased) that a leader is a builder of men and women who are bigger than they are and better than they dreamed. Among many things, this speech reminds me that we all have many opportunities to use language to communicate transformational ideas to those around us. Additionally, it should remind us that wo don't have to be world-class leaders to make dis inpact on other people.

Language is only one example as to how you can have a transformational effect on subordinates. linere are others. The important, point to remember is that transformational leaders somehow provide a vision that touches what subordinates value and how they ses thenselves. That is, it touches questions " $b$ " and " $d$ " in tize expectancy theory formulation. This is where I see the intersection of both transformation (emotional) and transactional (rational) models of leadership.

Your challenge is to communicate that vision to your subordinates (both full and part-time) and your patrons. After all, where else does vision come from but the shelves of stored experience that remain waiting to provide direction to the inany people who both use and work in your libraries. 


\section{References}

Bass, Bernard. Leadership and Performance Beyonc Expectations. New York: Free Press, 1985.

Bennis, Warren and Burt Nanus. Leadeis: The Strategies of Taking Charge. New York: Harper \& Row, 1985.

Burns, James MacGregor. Leadership. ivew York: Harper \& Row, 1978.

Harris, Sydney J. Pieces of Eight. Boston: Houghton-Mifflin Co., 1982.

House, Robert J. "A path-goal theory of leader effectiveness." Administrative Science Quarterly. 16, (1971), 321-338.

Lawler, Edward E. Motivation in Work Organizations. Monterey, CA: Brooks/Cole Publishing Co., 1973.

Levinson, Harry. Executive Stress. New York: Mentor Books, 1975.

McClelland, David. "The two faces of power." In Kolb, David A., M. Rubin Irwin, and James M. McIntyre. Orzanizational Psychology: Readings on Human Behavior, 4th ed. New York: Prentice-Hall, 1984, pp. 59-72.

Vroom, Victor. Work and Motivation. New York: John Wiley, 1964. 

has a Honeywell CP6 and have been developing over the last four to five years a catalog sustem which they call CATSUP, an online catalog which is designated CUBE for Carleton Union Bitliographic Enquiry. Thus, immediate negotiations commenced to see what might be done to acquire these for the colleges. We developed specifications of what we required, submitted these to our masters in Ottawa, who in turn passed them over to Carleton. One or the key things which created some difficulty was the necessity to be able to carry out subject searches in both French and English. This might not seem like it's important, until you start to try it. How do you program? The problem has been solved. The software does provide for this now. RMC presently is the guinea pig library in which it's being installed. The system was just put up after Labor Day. Staff training got underway in the next couple of weeks; we put the first record in the operating mode on 20 september, though we did have something like 75 records prior to that for test and trial. When I left we were up to something like 500 records in the system and things are beginning to check out. But this will be part of the unified system which Carleton's developing and will include a circulation system. Canadian Forces College has been making a bit of an impact on their organization. While they have been using the UTLAS at the same time, the college itself has been developing a statement of requirements for our new computer system, and I'm told that Cathy Murphy, who's over here representing them, was the one who in fact took the problem in hand, and was the key person in developing that requirement for the college. DSIS has, of course, been somewhat ahead of the rest of us. I understand they're snapping at the heels of your organization, Paul. The colleges and staff college libraries, are now beginning to come together. It wasn't possible before. And it looks as though we are well into the 20th Century. 


\section{PEDERAL LIBRARY AUD IUFORMTIOA CEUTBR COMHITEB}

Mr. James P. Riley

Executive Director, FEDLINK

Library of Congress

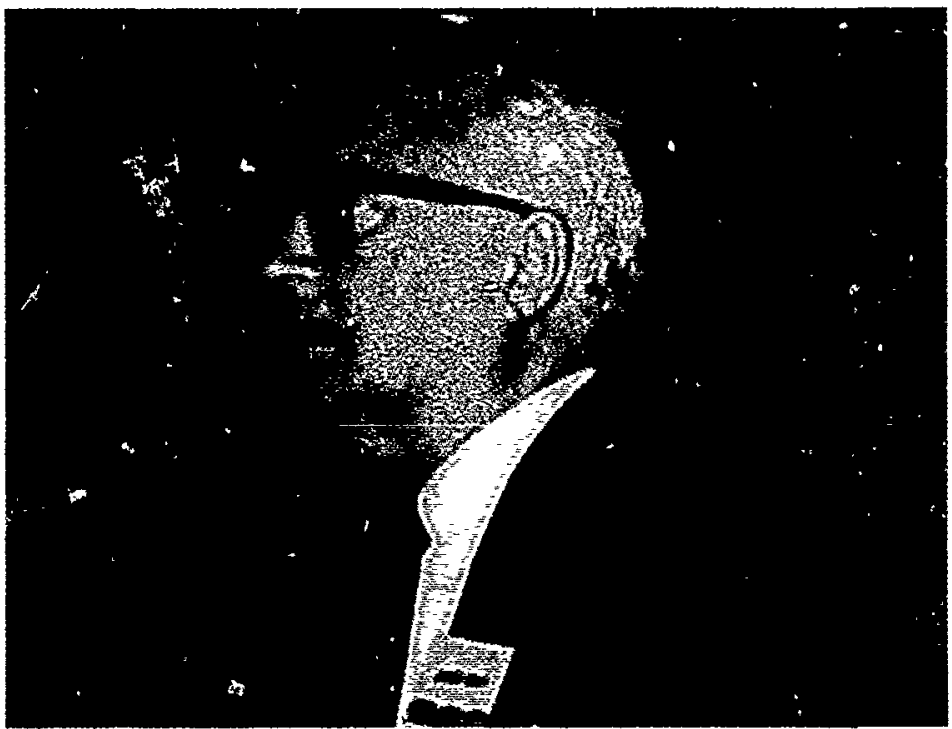

The Federal Library and Information Center Committee (FLICC) had a recent reorganization, announced in October 1984 Federal Register. One of the main activities in the past year has been an education subcommittee, and we're going back to regional workshops. Announcements dealing with regional workshops, where they'll be held, and the type of program we'll have, will appear in the Federal I,ibrary Information Center Committee Newsletter and the FEDLINK Technical Notes Calendar which is usually on pages 2 and 3 . If you don't get those items, please let me know and we'll see that you're on the mailing list. The FLICC also has established a procurement subcommittee, at the request of members, to prepare an FLC manual or guideline that deals with procurement. But this procurement manual will be addressed to procurement and contract officers. The subcommittee will be composed of both librarians and contracting officers and plans to produce a guideline this fiscal year.

The binding contract that the GPO has is with Ruzicka. We've been getting a lot of information from our members in Washington regarding that contract. I was on the telephone this morning and found out that GPO is going to withdraw them for non-performance and that was one of the things we've been working at. The real credit should go to Barbara Parett from International Trade Commission who has been very instrumental in gathering a lot of data. WERTZ is the one that apparently got the new award.

If you've read the FEDLINK Technical Notes, you found that the June-August issue lists 42 data base service contracts on the front page. We now have 51 , and we're still increasing them at the request of members who want us to subscribe to different data base services we don't presently have contracts for. Look carefully at this year's CFE packages, because attached to them are the interagency agreement letters. We're trying to put it in one package so you can get everything done at one time. This change is at the request of most of our members, and the Executive Advisory Council at FEDLINK approved it. Now, users have to sign the agreements and send there to FEDLINK. We will review them, the Library of Congress will sign them, and users will get a copy of the signed copy. If you have any questions about the packets, call the office and we'll instruct you what needs to be done. 



\section{DEPEHSE TECHICAL IMPORHATIOE CEETBR}

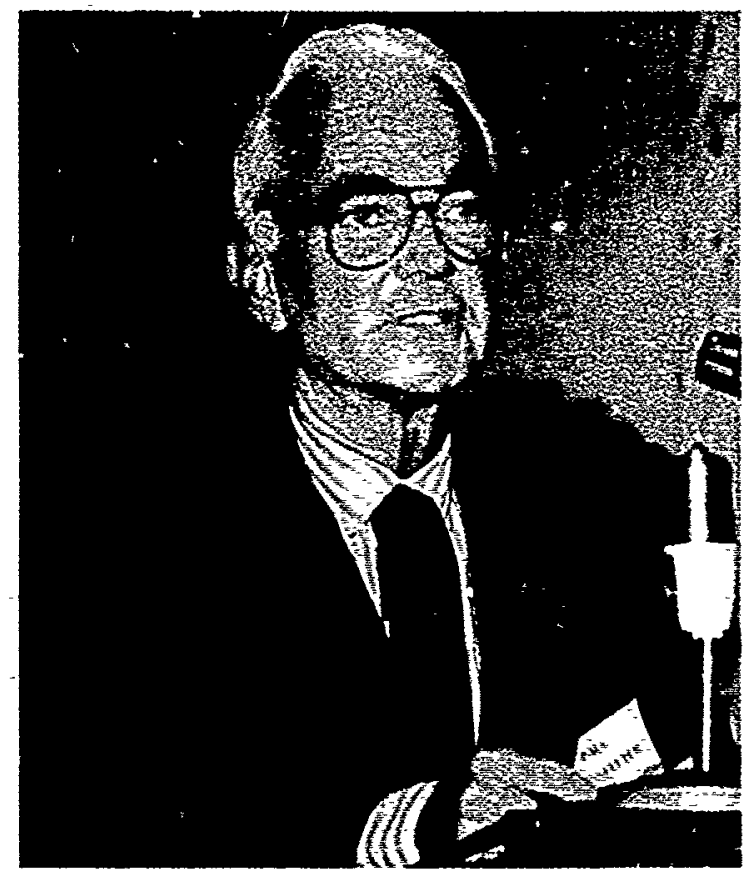

Mr. Paul Klinefelter

Defense $T \in$ chnical Information Center

I want to skim pretty quickly through those things that I see as affecting us in terms of the DOD and events within it. It seems to me that perhaps the biggest change involving the Defense Technical Information Center, the most apparent one, is the evolution of the DOD Scientific and Technical Information System as a distributed network. We are moving farther and faster toward this network of which you all are integral parts. Our goal is centralized data files with multiple independent nodes around the country, so that there is universal knowledge of where holdings are (at DTIC or wherever) and what the release conditions are. Libraries, information analysis centers, etc., meaning you, will increasingly be equipped or need to be equipped and function as little DTICs. New developments which affect this are in various developmental stages, such as the local automation model project--LAM--with mini anc micro computer aspects. LAM is experimenting in two directions. One direction, using a mini computer, DNA (Defense Nuclear Agency) is sponsoring and the other, for generally smaller library operations, using a micro, TRADOC's TRALINET is taking as an action project. These application packages will be extremely useful, though they're not here yet. We're putting them in the hands of users who know exactly what to do in testing their worth. This process involves a gradual evolution toward things like down-loading files from DTIC to the local nodes so that they have on-site everything we have (in their fields of interest) and can enrich it and add local resources to it. They are, in effect, little DTICs.

One of the most important new techniques is Gateway. Th.s one-pass reference capability, or pass-through, means you can ask a question anywhere in the network and it will go to DTIC as usual if you have an online access mode. But with Gateway it will pass through DTIC to all cooperating sources of information elsewhere so that you don't have to put the answer together from several sources. You get it from a single request through the system center. Gateway has a relatively easy-to-use access procedure and involves data analyses, merging by processing, and graphic presentation at your local site once you get the mix of information back. The work is currently being done on a test basis by the Lawrence Livermore Laboratory in California. It is an interagency 
project and the Department of Energy is very interested. DNA has had a formative part in this as well. These things are going to affect all of us. We will need your cooperation at DTIC in developing new techniques for the DOD.

Developmental. events within the Defense Technical Information Center will change the way we do things. We're designing a new data input system for both technical report descriptive information and for management data--that is work in progress and planning summaries, etc., which will include a Gateway capability. We are also working on the shared bibliographic input network. Fifty-four sites are already putting descriptive records and tech reports into the system under this shared bibliographic input concept!

Computer Assisted instruction (CAI) online for training in online access is getting closer and closer. We now have a support contract to work with, and CAI looks promising. An electronic documents system that has a digital imaging and printing system will revolutionize the way we do things and will be a model that any organization of any size among you could use.

The so-called CENDI (Commerce, Energy, NASA and Defense Information) Group is sponsoring more and more joint projects to develop techniques that will work interdepartmentally as well as within the Defense Department.

Within our chain of conmand, there are some changes. I suppose the one closest to us is the retirement of Hugh Sauter as administrator. He was both a librarian and an engineer. Kurt Molholm has succeeded Mr. Sauter as administrator. He's an ADP specialist. This will bring a new capability into that very important aspect of our lives. He has degrees from the University of Oregon, from George Washington; and is a graduate of ICAF. He's a charger.

There's something that affects many of you--a new certification process to establish U.S. government contractors' eligibility to have access to controlled but unclassified technical data. A new limitation statement has been added. It's complex and will take a to set up. It creates a new category of release.

There seems to be increasing interest from the Inspesctor General in incomplete input of in technical reports to the central file, and management data as well. This is the fourth year the IG hasemphasized this. This is a very great concern of ours and, of course, it's going to seep down to all of you.

Other significant personnel changes: Dr. Hicks is the new Undersecretary of Defense Researching and Engineering; Col Carter has replaced Dr. Edith Martin temporarily; but Dr. Leo Young is still Director of Research and Lab Management. 


\section{AIR FORCE}

Ms. Dorothy A. Gohlke

Assistant Air Force Librarian

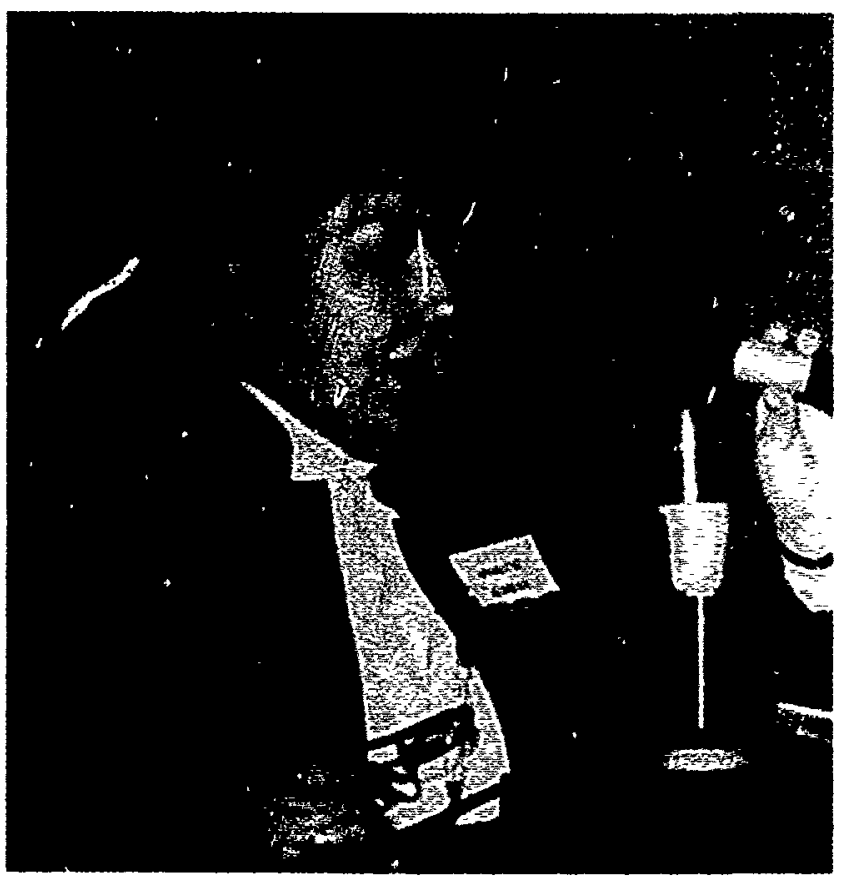

Air Force has followed its recruiting motto this year--"Aim High." I'll give you a quick recap of what's going on among personnel, library issues, training, and automation, and contracting out in the Air Force, and I'Il try to hit the highlights. Tony is an excellent writer and I'll see how well I abbreviate.

We have seen a changing work force in Air Force. We have had two more major changes of command this year to follow on the four major changes we have had in the last year and a half. Virginia Eckel retired as the Director of the Air Force Institute of Technology and was succeeded by James Helling. Alice Roy has taken over TAC Command because Marge Rambo retired just a few months ago. however, we have done something in the Air Force to solve this problem. We have finally followed our sister service, the Army, and we now have an intern program. We're very fortunate that this is being funded centrally through what we call OCPO and we have eight young interns. (Annette introduces the interns to the group.)

In Air Force we have a program called "Program Excellence." We are setting up very strong standards; they change annually to get our libraries to again "Aim High" in reaching for excellence. This year, 52 percent of our libraries managed to earn the Certificate of Excellence. We're thinking up new standards for next year. We want our people to continue to strive.

In libraries, on 1 October, Headquarters Air Force District of Washington was activated at Bolling $A F B$ as a direct unit. One library, a base library, was affected. It left MAC and is now its own operating unit.

We had a first in Air Force facilities this year that was quite exciting. At Langley AFB, Virginia, David Smith managed to have the first porta structure. We now have one in the Bethel Manor Housing area, and we're in the prosess of having four more put up overseas in the PACAF region. We find this is a marvelous new option for getting around congressional lack of support for new construction. We buy porta structures as equipment items since they are 
pre-engineered and portable buildings. In that way, we have managed to solve a terrible problem in the Air Force in building new libraries. However, we have gone forward and there were approximately 20 major renovation projects in the Air Force this year. As you know, management personnel, facilities, and resources continue to be a problem, and we are finding sojutions to that.

Training has become a major issue in Air Force (as I think it is with all our government agencies), and finding enough money and time to get people trained faster and more efficiently is an ongoing problem. This year we were fortunate to have our fifth annual ALA-connected Air Force workshop, and over 130 librarians attended. We're formulating plans to hold an Air Force workshop at SLA, since about 50 percent of our librarians belong to SLA, and we have another 50 percent that are what we call managemerit-directed..-they head over 160 libraries.

Besides our eight intern programs, we also have five slots centrally $f$ unded by OCPO to the American Management Association, the so-called miri-MBA course. Five people from the Air Force libraries, two at base level, two at MAJCOM level, and myself were very fortunate to be selected to go. It's an outstanding course. If any of you are looking for an excellent trajining course to see how our fellow members operate at the corporate level in private enterprise, this is it. I found out they don't operate any differently than we do, except for the bottom line profit margin. It's an outstandirg course and you should look at some of the AMA courses if you have not already taken advantage of them.

We also do a great deal of training at the MAJCOM level. This year we had a USAFA conference which I was fortunate enough to attend. We have had one in TAC and are encouraging all of our commands to have workshops, every year if possible, if not every two years, to have their librarians get down to what we call the nitty-gritty.

Automaition has not passed the Air Force by. Air University has just signed a contract with Geac, and as you saw at the Air Force Academy Library, they already have it in operation. So we're very pleased to have our two largest institutions well on their way to full automation. Europe is tacking onto the Army system and will be on Geac within the next few years. They'll be bringing most of their libraries on line starting, of course, with Germany. We have several commands that are trying to automate command-wide for our base libraries. We're looking at an automated procurement system since we have central procurement. We have a very large central procurement with money that we fund out of our office, and we want to get an online automated system going for our 160 libraries. We are also doing a great deal of work with the IBM PC.

Contracting Out: Aside from two changes, contractors at Arnold AFS, Tennessee, and Vandenberg AFB, California, Air Force 11 braries have been spared both cost comparison studies and contracting out. However, we recognize that both are a distinct possibility, and we encourage our librarians to get smart to do their own cost and management analyses before they are directed to do so. I would like to mention one contracted library that we have. If anyone wants to apply for this, they may do so: it's in Thule, Greenland. I would like to point out that Judy Hawthorne, as the new Space Command Librarian, has managed to get a professional librarian position in that contract and has just brought on board a Danish professional librarian. Any of you who know how to speak Danish and would like to apply for that position at some point in time, see Judy.

That's the Air Force's "Aim High" report. 


\section{APMI}

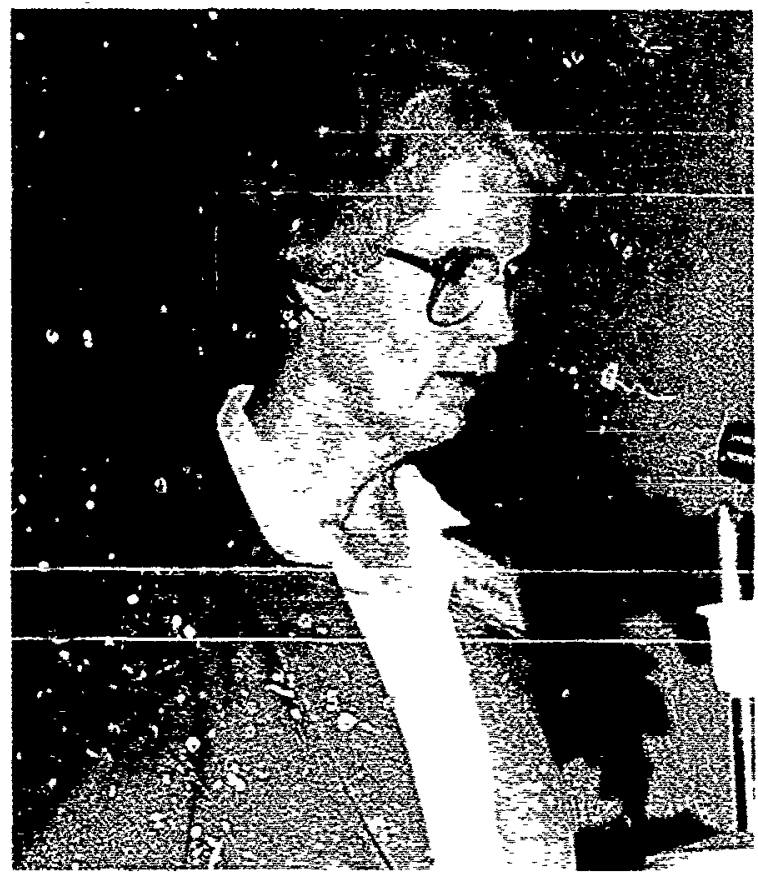

Ms. Mary B. Bonnett

Army Library Management of fice

I listened to Dr. Rader yesterday and I'm trying to follow as many of his principles as possibje. I only halfway followed one of them, sit up front, but I didn't get quite far enough up front.

Many of you knc: Dorothy Fiske is head of the Army Library Management office (ALMO). It's not Dorotiny Fiske any Ionger, it's Dorothy Fiske MaDysen as of 7 September 1985.

I have five tilings I'm going to talk about today: The OPM GS-1410 Register; our involvement with the National Information Standards Organization (NISC); the Army Library Career Progran Job Analyses Project; the Amny Library System; and the Department of Army reorganization in the information management area, AR $370-1$.

We have word from Jennifer -ker at OPM that the register is slated to be opened for applicants during February 1986. The exact dates will be pubiished later.

On the NISO, the Anmv Library Management Office (ALMO) is not a DOD voting representative on -he itandards development organization. This group develops standards in information systems products and services, bibliography, library and publishing practices, and library equipment and standards. If these different standards come up for review and voting, we get copies in our office and circulate t:!em to those DOD organizations which we are aware are interested in those standards. Our list is rather short, and we would not be at all unhappy to know of otrer organizations that are interested in reviewing the starifards and what subject areas you're interested in. If you are interested and your orgar..zation will support you, just notify our office and we will get you on our list. I'm on the subcommittee that is currently revising $239-18$, the guidelints for developing and printing technical reports. We expect to have a draft out before the end of the jear for comments. 
We are running a job analysis for the librarian career program out of the ALMO. We have Marion Weiss from USAREUR in on a one-year training assignment to do this study. She will be interviewing many of the Army librarians to identify tasks that are performed in libraries, specifically what you do. From this, the career program appraisal documents are to be revised and brought more in line with the current practices. I think this was last done 12 years ago and we certainly know they've changed in that time. This will also be the basis of implementing the Army civilian training education and development system which will be an improved referral and training program.

I spent a good dea? of time and many of you have been involved with the development of an umbrella regulation for the Army Library system. This is scheduled to be effective 16 october 1985. This regulation incluies policy and standards guidelines and also includes a management reporting system which will be the basis of an annual statistical report on what's done in Army libraries. The Army is reorganizing many of their functions to develop an information management area. This has been going on for approximately six to eight months. It's been filtering down through the staff positions. The purpose is to implement the Paperwork Reduction Act and to put a top level, highly visible information manager on the Army staff. The top, visible position is the Assistant Chief of Staff for Information Management, Lt Gen Doyle. The areas that will be covered in the AXM Assistant Chief of Staff area are policy issues related to automation, telecommunications, audiovisual policy, publication, records management, and library policy. Our office was transferred to be operationally controlled by AXM effective 1 october 1985. An Information Systems Command has been created through the merging of Computer Systems Command and the Army Communications Command. In picking up a few extraneous, related organizations, this command has operational control in functions in the automation telecommunications and audiovisual areas at this time. There is to be a review study to determine how the functional elements and resources for libraries and publications should be orderly transferred. The one question that has come up that I hadn't heard until Tuesday was, "When do libraries become part of the Information systems Command?" As I understand it, the only libraries that will become a part of the Information Systems Command are those that are serving units within the Information systems Command, such as the Headquarters Army Communications Command Library at Ft Huachuca. But the libraries that have been AMC or TRADOC libraries will remain with the command that they have been serving. They will receive functional direction through the channels that come down from the AXM but not the Information Systems Command. There will be more changes and, hopefully, we are going to get some definitive written guides, but, until that happens, I think the best advice is "Don't do anything until you see it in writing." 
LeVI

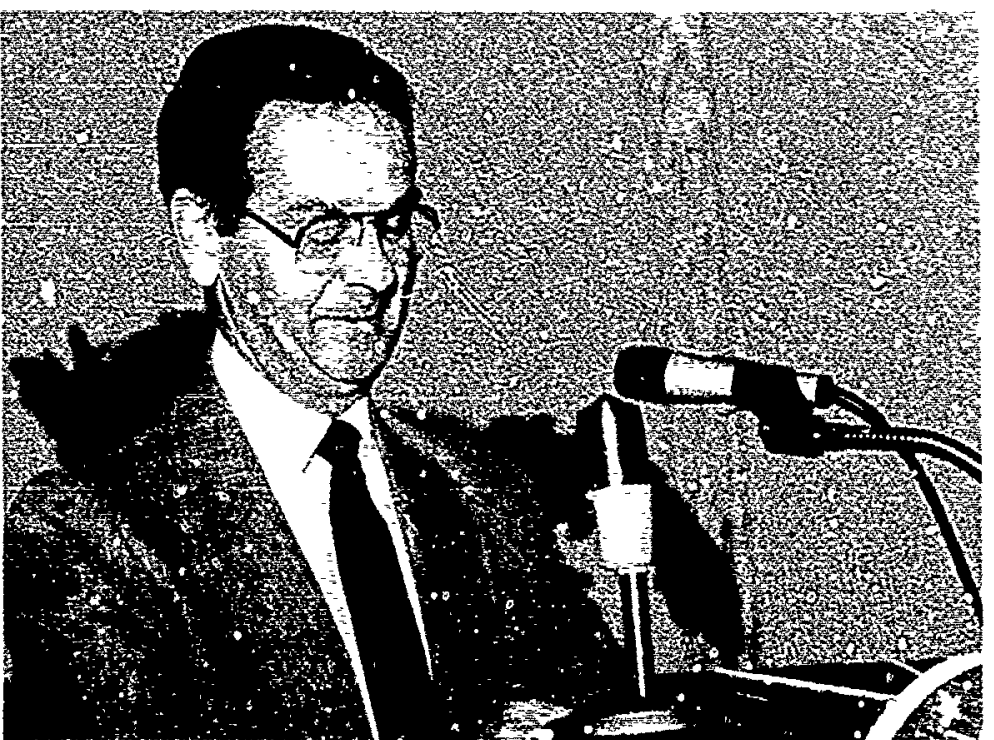

First, the Navy union list of serials (that is currelity in its first revision and which, despite its contractor inaccuracies, is and has proven to be a very worthwhile and valuable tool for the some 50 contributing technical, medical, and other special Navy libraries throughout the country) will be revisea and updated in the very near future. The contract difficulties with the vendor of that first revision, Sigma Data, have been significantly resolved. It's not likely, however, that Sigma Data will receive the contract for the next revision. At any rate, work on the new update should be starting soon. As an aside to this, there are still in our office a number of hard copies of the union list as well as a number of microfiche copies. If anyone is interested in obtaining a copy either in hard copy or microfiche, contact stan Kalkus.

The pilot periodical resource sharing project that includes the departmental Ilbrary, as well as the libraries of the Naval Research Lab, the Naval Surface Weapuns Lab, and the Naval Ship Research and Developrent Center Library, seems to he working out acceptably to the participating libraries. Nonetheless, any Navy 1:braries interested in possible future participatio. in this periodical resource sharing program or information can contact Stan, or pete Imhof at NRL, or Marshall Hughes at NSwi.

Although still in an incipient stage, oackground materials iave ben coilected and serious discussion begun with Stan and the personnel people within the Navy on the Navy's possible implefientation of a Navy librarian isreer program--similar to that in place in the Air Force and Army.

One comment about contracting out in the Nary. Mcst Navy librarians are aware that there was $a$ blanket exemption issued by the orfice of Naval Materiel perhaps a year ago exempting laboratory librailes from the contracting out process. Howevar, the secretasy of the Navy abolished the Office of Naval Materiel about six months ago, and $I$ don't think anyone really knows whether the exemption is going to continue to $\mathrm{r}$ in through some other office.

For those of you who don't already know, the Navy librarians are proud and excited that one of our own, Bonnie Davis, is the new chairperson elect of the Military Librarians Section of the Special Library Assoctation. 

I want to encourage ail of jou, whether jou are SLA members or not, Military Libsary Division members or not, to attend the sext conference in Boston. We have an exciting program envisioned; it's going to be called the International Defense Information Conference. It's a conference within a conference. We have already recesved wora fron the Australians that they are interested. Keith crouch is going to be participating. We are hoping to get someone frcm sandhurst. Jerry Gamoro from James Publishing and Mr. Crane from Janas Publising, New York, will also be on the program. We hope to have cther publishers also to tell us of theis work in the area of excellence in publishiny, because the theine is "ixcellence in the World of Information." For ihose of ynu who are not SLA members, I would like ts encourage you to join.

We have lwo things that I would like to bring up right now to members of SLA; (1) We reed more input on the logo; we need more input on the builetin; and we need more input to Linda Evans on the job slearing house. (2) We also need members for a long-range planning commitiee. Sn, any of you who are interested in sny of tilese areas, or any of you who are interested in anything, contact me--communication! I hereby adjourn this meeting. 


\title{
Clos Img REHARIS
}

\author{
Mr. Paul Klinefelter
}

A few short announcements: Linda Evans from Rome Air Development Center is attempting to build up RADC's holdings of its own reports. There are huge gaps. She's just gradually finding out the magnitude. The RADC collection is ircomplete by possibly as many as 1600 titles, which is a lot. Any of you who have RADC reports, please look to see what you have, and either ask her whether they are among the missing ones or simply send them to her.

It's also been mentioned that she is, in effect, the job locator for the Military Library Division. She knows of a few job openings, and for any of you who have people who are looking, she's there to match jobs and possibilities. Also, Egon Weiss from West Point reminds me that the Military Library Division has a parallel in ALA's Amed Forccs Librarians Group. They had a meeting in Chicago tris summer in whicn some of us oarticifated and came up with a series of recommendations. Some of the recommmendations seek to give as much political influence and clout to this military group within ALA as possible, There are a number of steps they recommended he taken. Please see Louise Nyce or Egon WGiss for details. The newly elected board members of this ALA Division are Katherine Sikes, President Elect; Elizabeth Lane, Secretary; and Louise Nyce, the Army representative.

This has been a wonderful conference! I want to pay tribute to all of you. There has been so much interest and it's been a vibrant group.

(Mr. Klinefelter then recognized attendees from the U.S. Embassy in London, Panama, Hawaii, Germany, Spain, and Alaska who had gone to great pains to be present). Our scope is becoming international and nowhere more than in the Canadian group which has been so well represented.

These workshops are healthy and in good shape. This is a lively institution with a mission, a successful past and, particularly, a very promising future. We can reflect with pride on what we have done. There's a lot of continuity, and the farther we go, the more continuity is being built into it. I have been talking with some of you about attractive sites for future workshops. This thing is going to $\mathrm{fly}$, continue to fly, and fly better.

The next workshop will be the $30 \mathrm{th}$ which, in itself, is a milestone. It will be held 14-17 Oct 86 in New Orleans, which is not to be sneezed at as a site. I've never even been to New Orleans. It's to be sponsored by the Corps of Engineers. Abbott Martin, I want you to stand as Corps of Engineers host. Be nice to him, he' 1 h have something to say about getting you to New Orleans. His local host and a very charming lady who has had a lot to contribute during this conference is Barbara Fox.

I: 1 foliow a little tradition that has become established. You know that when we held the 23rd Workshop in Alexandria's old Town, the old 18th century port city of Alexandria, one thing that I used all the time to get people in and out of those narrow halls was a town crier's bell, very characteristic of that region because in the $18 \mathrm{th}$ century, if anything important happened the town arier went down the street and rang this thing to get people's attention. Our town crier's bell has since been passed from host to host. I want to do that now. I've looked it over closely. In the first place, it had never been shined 
so the Air Force naturally shined the hell out of it. It may be lighter, but it's pretty. The second thing, looking a little closer, it turns out that a very nice fact has been engraved on it--that the Air Force Academy is our first three-time host. It's going to take a long time to catch up to them. That was a very nice gesture. They could have put "Beat Navy" on it, but they didn't. I am kind of grateful for small favors on that one. In any case, Barbara, would you come up and let me officially transmit this thing? I should mention that the following workshop is also in very good hands. The 31 st will be held at the brand new (but super secret of course) Headquarters for the Defense Inte'ligence Agency at Bolling AFB in Washington. This workshop will be something like opening a new Mormon church. If you get in this time, you better go because you'll never get another chance. Herb Holtzbauer, who had wanted to do this for a long time, retired but his successor is here, Bill Crislett.

Paul Klinefelter then thanked the Air Force Academy for sponsoring the 29th MLW and pronounced the workshop closed.
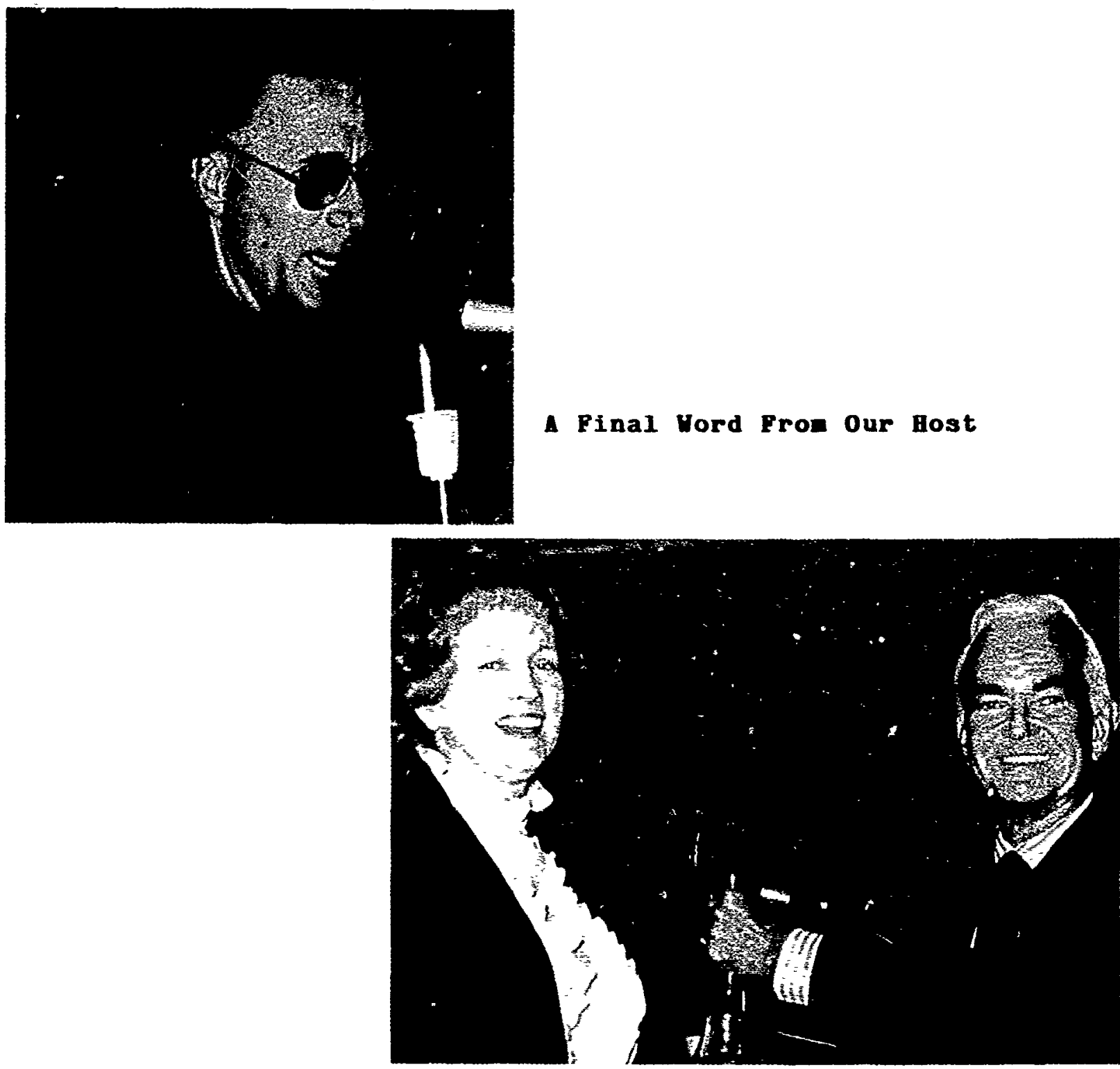

Passing the Bell to

Eext Iear's Host 
A P PENDICES 

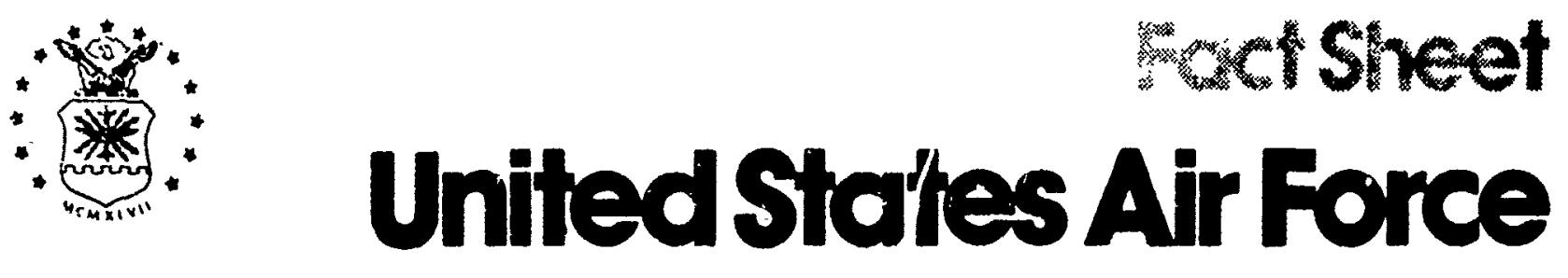

U.S. AIR FORCE ACADEMY, PUBLIC AFFAIRS, USAF ACADEMY, CO 80840

(303) $472-4050$

\section{AIR FORCE ACADEMY HISTORY}

The idea surfaced almost four decades ago, but did not become a reality unt1l April 1, 1954, when President Dwight D. Eisenhower signed the bill escablishing the U. S. Air Force Academy.

Many of America's ploneer aimen advocated the creation of an academy to prepare officers especially for the air service. One of them, Brigadier General William "Billy" Mitchell, tried in vain to persuade first the government and then private interests to establish such a school.

In 1948, the Alr Force appointed a board of leading civilian and mllitary educators to gian the curriculum for an Air Force academy. The idea made little progress outside the Air Force, until 1949 when Serretary of Defense James Forrestal appointed a board of military and civilian educators. The board was headed by Dwight $D$. Fissenhower, then president of Columbia University, and Robert L. Stearns, president of the University of Colorado, to recommend a general system of education for the Army, Navy and Air Force.

In 1950, this board found the needs of the Air Force could not be met by a desirabie expansion of the older service academies. The board recommended that an Air Force Academy be established without delay and proposed that, in peacetime, not less than 40 percent of the regular officers taken into each service should be Academy graduates.

Congress authorized creation of the Air Force Academy in 1954. Harold E. Talbott, then secretary of the Air Force, appointed a commission to assist him in selecting the permanent site. Aftex traveling 21,000 miles and considering 580 proposed sj.tes in 45 states, the comenission reconmended three locations. From those, Secretary Talbott selected the site near Colorado springs. The state of Colorado contributed $\$$ million toward the purchase of the property.

The first Academy class entered in Juiy 1955 at temporary facilities at Lowry AFB, Denver. Construction at the permanent location also started in 1955 and was sufficiently complete for the Cadet Wing to move into its permanent home in late August 1958. Initial construction cost \$142 million.

Two hundred five mambers of the first cjass were conisisioned as secchi lieutenants in June 1959. That class graduated the fewest cadets. Five years later, President Lyndon B. Johnson signed a bill into law iuthorizing $A=t$ :dent increase in the Cadet wing from 2,529 to 4,417 .

Expansion began in June 1964 when 1,002 cadets entered the Academy. To provide facllities for the increase, Air Force officials programed $\$ 40$ million during a five-year pertod beginning in fiscal year 1965.

Perhaps, though, the most controversial event in Acadeny history was the admission of women. 



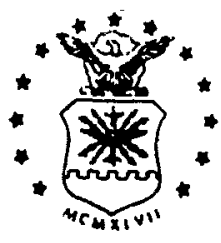

\section{AIR FORCE ACADEMY CADET CHAPEL}

Soaring 150 feet toward the Colorado sky, the Air Force Academy Chapel is an all-faith house of worship designed to meet the spiritual needs of cadets. It contains a separate chapel for each of the three major religious falths represented in the Air Force-protestant, Catholic and Jewish--plus an all-faiths room for members of other faiths. There are two main levels, with the Protestant nave on the upper level. The Catholic and Jewish chapels and the all-falths room are located beneath it. Each chapel has its own entrance and services may be held simultaneously without interfering with one another.

The aluminum, glass and steel structure features 17 spires. There is no significance to this number. original designs were too expensive, so changes were made, among them a reduction in the number of spires. The changes did not alter the basic design or the interior square footage of the chapel, however.

The chapel structure cost $\$ 3.5$ million to build. Furnishings, pipe organs, liturgical fittings and adornments of the chapel were presented as gifts from private individuals and donations from Easter offerings made at $A$ ir Force bases.

Princlpal designer-architect of the chapel was walter $A$. Netsch $J z$. of Skidmore, Owings and Merrill of Chicago. Construction was by Robert E. McKee, inc. of Santa Fe, N.M.

\section{Protestant Chape I}

The tetrahedrons form the walls and the 95-foot-high pinnacled ceiling of the Protestant Chapel. Stained glass windows form ribbons of color between the tetrahedrons. Eight basic colors graduate from cool to warm with the narthex (entrance) to the chancel (altar area). The floor is gray-white terrazo.

The chancel is set off by a crescent-shaped, vari-colored reredos behind the altar. The 14- by 45-foot reredos represents the arms of God ready to receive anyone who goes there in prayer. Semi-precious stones from colorado and pietra santa marble from Italy cover its 1,260 square-foot area. 
A sleek marble slab 15 -feet long, formed in the shape of a ship symbolizing the church, is the holy table, or altar. Four travertine marble legs support the table.

Focal point of the chancel is the cross suspended over it. Executed in aluminum, the cross is 46 feet-2 inches inigh, 15 f feet wide and weighs 1,200 pounds.

Surrounding the curved steps of the altar are 12 kneelers done in needlepoint by officers wives clubs throughout the Air Force. Each kneeler, except one, contains a cross seen in the historical development of representative art within the Protestant church.

The pews, which can seat 1,200, are of American walnut and African mahogany. They were sculptured so the end of each pew resembles an alrplane propeller. The backs of the pews are capped by a strip of aluminum similar to the leading edge of an aircraft wing.

Perched in the choir loft above the narthex and reaching the uppermost heights of the chancel is the classical pipe organ. Designed by Walter Holtkamp of the M. P. Moller Co. of Haqerstown, Md., the organ has 79 ranks and 67 stops controlling 4,334 pipes. The largest pipe is 32 -feet $h i g h$ and the smallest is pencil size.

\section{Catholic Chapel}

The focal point of the Catholic chapel is the reredos behind the altar. An abstract glass mosaic mural, the reredos is composed of varving shades of blue, turquoise, rose and gray tessera to form a portrayal of the firmament. Superimposed on the mural are two 10-foot-tall marble figures, "Our Lady of the skies" (The Blessed Mother) on the left, and on the right is the Guardian Angel. Above and between these two figures is a marble dove, symbolic of the Holy Ghost.

In front of the reredos is the altar which was dedicated by the 1ate Francis Cardinal. Spellman on sept. 22, 1963. The altar has a large table top of polished marble mounted on a cone-shaped pedestal. Above the altar is a six-foot sculptured nickel-silver crucifix. Altar furnishings are of high gloss nickel-silver.

The side walls of the chapel from floor to ceiling, are panels of amber glass which cast soft brown colors across the chapel. Between the amber glass panels are strip windows of multi-colored cast glass set in precast reinforced concrete. 
Along the side walls are the 14 stations of the cross, carved from four-inch-thick slabs of marble. The recessed backgrounds in the sculptures are multi-colored tessera.

Both the stations of the cross and the reredos were designed and completed by the late Lumen Mnrtin winter, who created "The Conversion of st. Paul" for the facade of the Church of st. Paul the Apostle in New York City. The Carrera marble in which the figures are done was taken from the same quarries from which Michelangelo drew his stone.

The pews, which seat 500 people, are of American walnut trimmed in satin finished stainless steel.

There is a confessional and reconciliation room at the rear of the 55h- by 95-foot nave. Off one side of the narthex is the baptistry and on the other side is the blessed sacrament room, the walls of which are marble chips and semi-preclous Colorado stones.

The classical pipe organ, placed in the 100-seat choir loft, in the chapel was also designed by Walter Holtkamp and built by M. P. Moller Co. The organ features 36 ranks and 29 stops to control its 1,950 pipes.

\section{Jewish Chapel}

Architecturally, the synagogue is a circle within a square. The circular design symbolizes the global mission of the Air Force and the everlasting presence of God--there is no beginning and there is no end. The surrounding foyer is paved with 1,631 pieces of Terusalem brownstone donated by the Israeli Defense Forces.

The walls of the foyer are purple stained glass panels alternating with green and blue stained accent windows. The circular walls of the synagogue are panels of translucent glass separated by stanchions of Israeli cypress.

The focal point of the Jewish Chapel is the Aaron Kodesh, the Holy Ark, whlch shelters the scrolis of the Torah. The Eternal Light hangs to the right of the Ark. Nested in three stars of David, it symbolizes the ever-present God within the life of the Tewish People.

The synagogue is the oily one of the three cadet chapels with individual chairs for the congregants. It seats 100 people. 
The all-faiths room is a neutral place of worship for small groups and other denominations. It is purposely devold of religlous symbols to make it acceptable to a rarlety of religious g.oups. An altar is avallable which can be adapted to soveral types of service, including Buddhist. The all-faiths room seats about 25 people.

Current as of January 1985
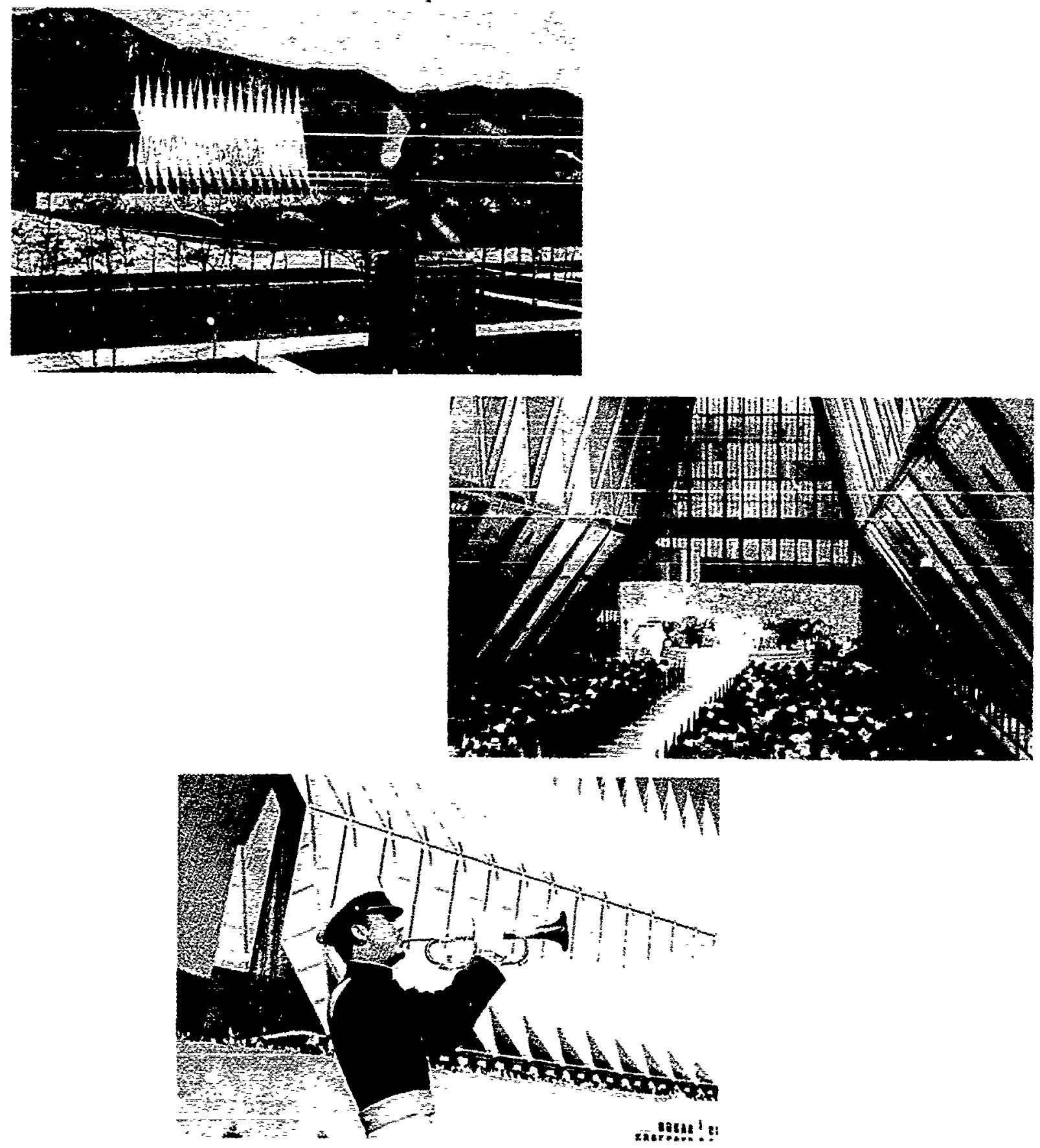

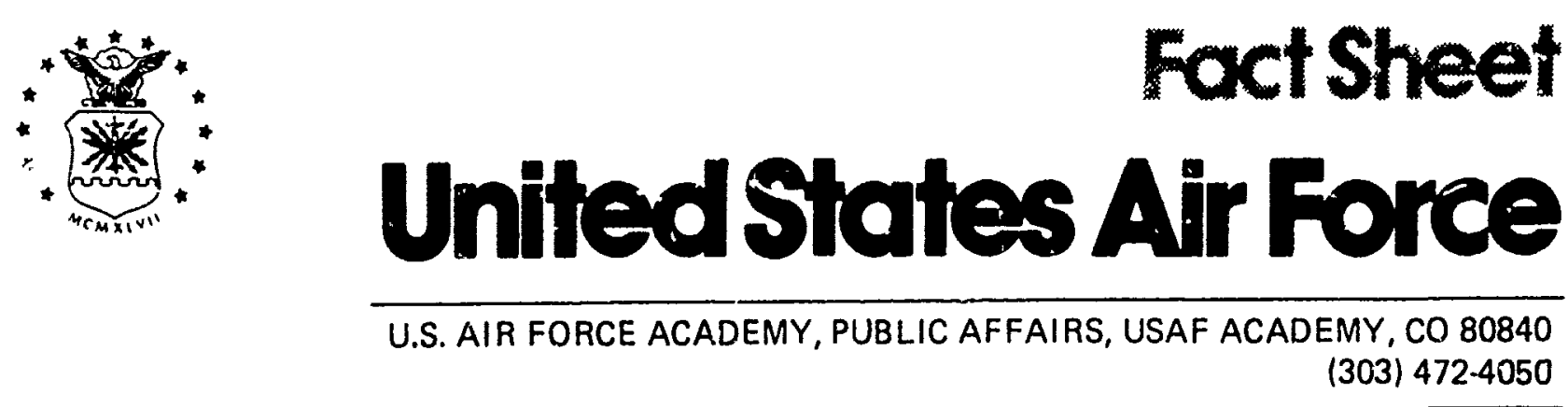

THE FALCON

Sports audiences across the country have been intrigued and delighted by the aerobatics of the falcon, flying mascot of the Air Force Academy Cadet Wing. Trained and handled by cadet falconers, the bircis soar and dive around the stadium, sometimes zooming low over the heads of the spectators.

Most of these public appearances are in conjunction with football or basketball games, or other athletic contests in which cadet teams play. All Academy varsity sports teams are called the "Falcons."

\section{History}

Members of the Class of 1959, the first class to enter the Academy, chose the falcon as the mascot of the Cadet wing Sept. 25, 1955. The first class felt the falcon best characterized the combat role of the U.S. Air Force. When the cadets selected the falcon, they did not specify any particular species. As a result, any falcon can serve as the mascot. Falcons aze long-winged hawks.

Some of the characteristics of the falcon which led to its selection are:

--Speed - authorities say rat falcons can attain velocities exceeding 100 miles per hour in "stoops" or dives on their prey.

--Powerful and graceful flight - with strong, deep wingbeats, the birds maneuver with ease, grace and evident enjoyment.

--Courage - fearless and aggressive, falcons fiercely defend their nest and young against intruders. They have been known to unhesitatingly attack and kill prey more than twice their size.

a human.

--Keen eyesight - about eight times sharper than that of

--Alertness, regal carriage and noble tradition.

Although falcons are members of the hawk family, they differ in that falcons have long pointed wings and dark eyes. There are five types of falcons native to North America, ranging in size from two feet in height to as small as five inches. These birds are the white 
Artic gyrfalcon, largest; the peregrine falcon sometimes called the duck hawk; the hmerican merlin, or pigeon hawk; the prairie falcon; and the American kestrel, sometimes called a "windhover"or a "sparrowhawk."

Through the ages all types have been trained by falconers, usually for hunting. In medieval Europe, the gyrfalcon was reserved for kings and princes while the peregrine was flown by nobles of ducal rank. Recently many countries have enacted legislation to protect the birds whose existence has become precarious. Colorado, along with many other states, has similar laws.

\section{Falcons At The Academy}

A splendid peregrine was the first falcon presented to the Cadet wing Oct. 5, 1955. It was named "Mach 1" indicating the speed of sound. "Mach $1 "$ is still the official mascot name, although each bird receives an individual name from the cadet falconers.

About 10 falcons are kept in the mews north of the cadet area. The majority of the birds are prairie falcons nat $e$ to Colorado. Cadets train both the tiercels (males) and falcons (females) to perform flying demonstrations.

In the past the Academy has been fortunate to have had a white gyrfalcon represent the Cadet Wing. Early gyrfalcon mascots were Atholl and Pegasus. The most recent and long lived white gyrfalcon, Baffin, got her name from the island in the Arctic Ocean where'she was captured with the permission of the government of Canada. Captain Richard Graham presented her to the Academy Nov. 20, 1965, as a gift from the 17th Air Force. Baffin died April 7, 1978, at the age of 13. During her years as queen of the mews, Baffin appeared at all home football games, during June Week and on parents' weekend, and she was the star on several television talk shows. Artist Donald Eckelberry, renowned wildlife painter, was commissioned in 1972 by the Association of Graduates to record her likeness for posterity. Baffin has been restored to her former beauty by highly acclaimed taxidermist Don Bowman. On Aug. 8, 1979, she was presented to the Cadet Wing by David Merrifield of Wildife World, Monument, Colo. She is now on display in Arnold Hall.

Since July 1980, the Cadet wing once again has a white gyrfalcon mascot to show to the public. Glacier, a male gyrfalcon, was taken from the nest in the Seward Peninsula of Alaska by an Academy sponsored search team on July 3, 1980. Although the Academy received permission from Alaskan authorities to take two ayrfalcons, a white one and a less rare gray phase gyrfalcon, the search team felt it best to take only cne. Glacier has already been the center of attention for many Air Force Academy official functions.

Experts said that falcons could not be trained to perform before huge audiences, that the birds would panic and flee. Since 1965, however, cadets have flown the birds at football and basketball games before thousands of spectators. 
Falconry is one of the extracurxicular activities offered to cadets by the commandant of cadets. The kcalemy Chief, Environmental Health Services serves as the officer-in-charge. There are usualiy 12 falconers, with four chosen from each new fourthclass (fresinman) at the end of the year to replace the seniors who will graduate. The new falconers begin training in January under the leadership of experienced upperclassmen ano the officer-in-charge. Without proper instruction, norices can physically harm the birds or adversely affect their training. Falconers' duties include daily checks of each bird's health and condition, daily training sessions during which the birds are fed $a$ measured ration of meat, frequent cleaning of the mews and routine sintenance of equipment.

\section{Training the Falcons}

Under specia: peimits issued by the U.S. Fish and. Wildlife Service and the Colorado Division of Wildlife, the Academy is permitted to propagate captive prairie falcons. SAnce 1974, most birds used for public exhibition have been producer. in the Academy breeding project and no wild birds have been taken. Due to the success of this project, birds excess to Academy needs have been transferied to agencies for use in educational programs dealing with raptors (birds of prey). When the Academy production is lower than its neecis, the Peregrine Fund Project at Fort Collins, Colo., supplies the Academy with their excess prairie falcons. Annual reports on ali activities of the Academy falcon program are submitted to state and federal wildiife conservation agencies.

The striking Colorado prairie falcon is the bird used by cader falconers in flying demonstrations. The birds are flown throughout the year, weather permitting, to keep them in condition. Between May and October, when the birds are molting, the training is minirized to prevent damage to new feathers.

Young birds hatched in May or June grow rapidly and by the end of July are fully feathered and ready for training. The first step is to acquaint them with the "jess," a short leatier strap fastened to each of the bird's legs. The next stage is called "manning," a procedure to let the falcons become accustomed to the presence, sounds and smell of people. Each falcon has a six-foot leash coupled to the jesses, and is carried on a falconer's gloved fist. In this manner the bird gradually loses the fear of moving among crowds of people. A leather hood is used when necessary; when it is placed over the bird's head the falcon will remain calm.

Next, a long stout string called a "creance" is used to secure the bird. One end of the creance is fastened to the base of a portable outdoor perch, and the other end is fastened to the jesses on the falcon's legs, thus giving the bird a restricted flight range. The falcon is taught to hop, then flutter, and finally fly the length of the creance to the falconer for food. This is followed by training the bird to fly to the lure, a rectangular shaped leather pouch to which meat is attached. The falconer whirls the lure in a circle on a 10-foot cord, and the bird quickly learns to strike it in mid-air, 
carry it to the ground and dine on thie food. When the falcon flises unhesitaringly tc the lure every time, the creance is ramoved and the bird is permitsed to fly fxee. A small battery powered transmittex is attached to tne falcon's leg so that, should the bird not come to the luxe as it has been txaineci, the cadet falconers will be able to. follow anc safeiy recover the falcon. As the falcon stoops toward the lure in free flight, the lure is jerked aside, causing the falcon to fly up, circle and make another pass. This procedure is repeated several times hefore the bird is allowed to strike the lure in mid-air.

Six weeks or more are required to properiy train an "eyas" or yo:.ug falcon. When a bird is ir cop conáition, it is able to fiy for moxe than an hour and make rapeated stoops. Although falcons can be trained to perform, the hirds are never totally domesticater and remain wild creatures with strcsig, independent spirits.

Current as of Iuly 1985

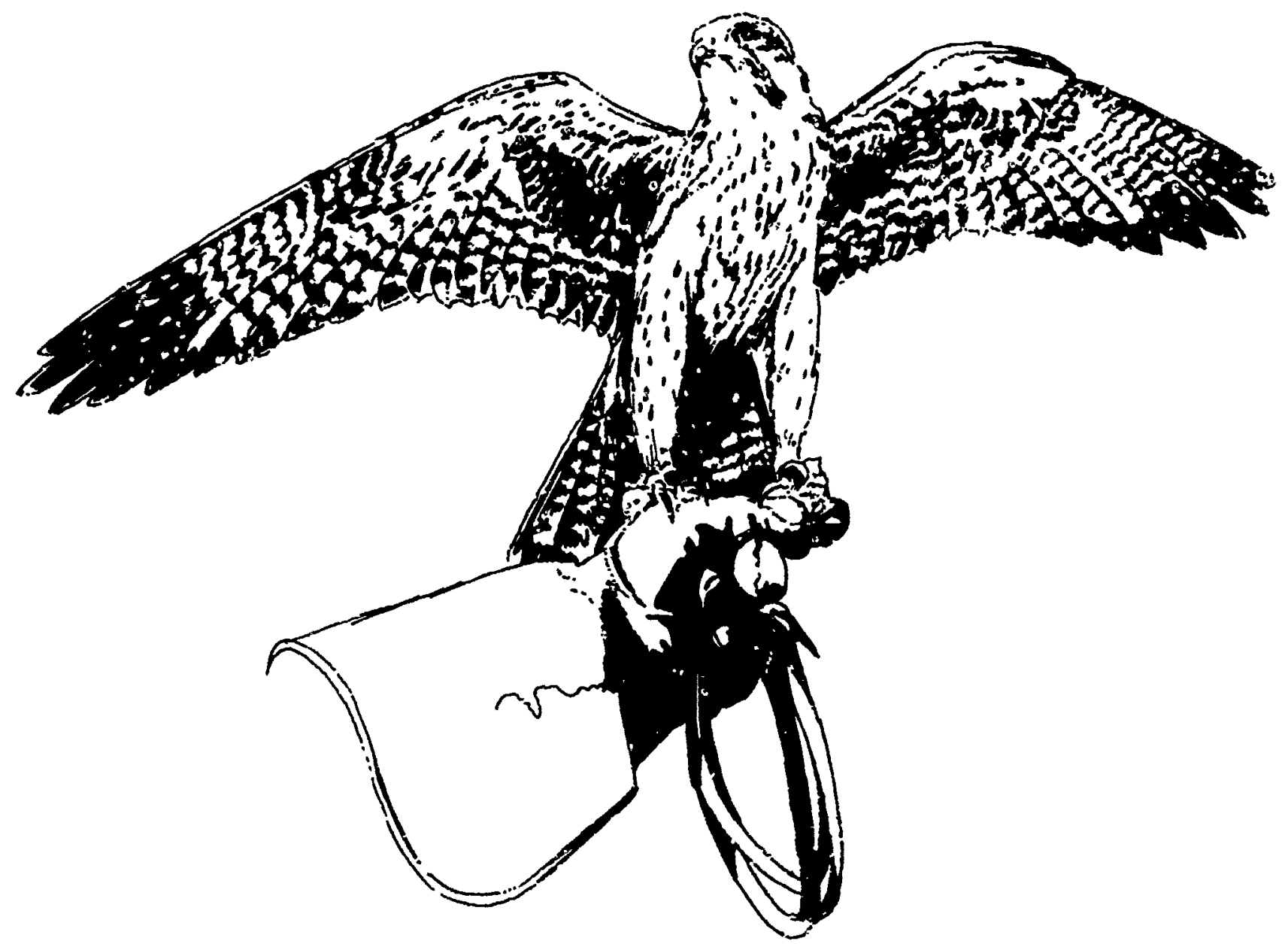




\section{Ginbel Aerowautical fistory Collection}

The Gimbel Library, which is ricused in a secure and huridified area, comprises ar. amazing array of items pertainine to the riscory of rlight. Five-thousand-yearold seals carved fron semi-precicus stones (used to make clay tablets) and some of the firtot prinited allusions to flying documert man's earliest dreams of flight. There are drawings, rare coznemorative metals, and otiner books about early exferiments with wings, initial balloon ascents, first parachutes, kites, pyroteshnics, historic iviation flights, imaginary voyages in space, and urimitive ruckets which contribute to a kitleidcscope of the history of man's aeronautica:


triumphs. Larly flight manuals, satalngs of aircraft enuipment, and other materials relating to airships, mizitary aviztion, and air acciderts recort the technological. progress and problems of modern aeronautics. Femarkably too, several most unusual media in the Gimbel Liorary depict aeronautice. events--chinaware artifacts, bookends, snuff boxes, bowls, clippings, tans, military insignia, model airpianes, matchboxes, playing, gregting, and post cards, children's games and toys, and even valentines!

French and Erglish editions predominate among the approximately 7,600 books in the coliection, which encompasses more than a dozen languages. Eigint tooks zra priceless incunabula (books printed beiore 1501) and one-fourth of the editions in the coilection were printed before 1850. Many of the books, in addtion to their aeronautical significance, are bibliographic treasures beculse they are superb examples of fine book binding, printing, illustration, and typography.

Ore of orany exciting and fascinaiing topics extersively covered in the Gimbel Collection is the idea of imaginary voyages in space. Speculations on this theme atound in numerous editions, including Roger Bacon's treatise on wonders of the world De Mrabilibus Mundi (1542), Rostard's Cyrano de Bergerac, Fatlock's peter Wilkins, and several works by Jules Verne.

Autogracs: enthusiasts can scrutinize with great interest the more than 250 autographs, holographs, and inscriptions in the collection. There are many important letters written by pioneers of flight: Blanchard, Bleriot, Langley, Lunardi, Nontgoliier, Pilatre de Rozier, Santos-Dunont, the Wright brothers, and Count zeppelin. There are also extremely rare handwritten manuscripts from the Siege of Paris $(1870-1871)$.

The Gimbel Library is greatly enriched by approxinately 5,000 prints, portraits, and views, and includes engravings, etchings, woodcuts, lithographs, and drawings--in jlack-and-white and in color. The prints are grouped in 49 portfolios: making a truly unique pictorial history of aeronautics, and containing such headings as "Blanchard and Lunardi," "Kites," "Parachutes," "War Balloons," "Japanese Prints," "Aeronautical Cartoons," "Posters and Playbills," "Sheet Music," "Moon Material," and "Currier and Ives." A superb example of roremerge painting is a special prize. 
Altiough Colonel Gimbel had intended the historic first flight of the Wright brothers 'o be the original terminal point of his aeronautical collection, he later expanded his holdings to include the post-1903 period--including the accomplishments of Lindbergh and Amelia Earhart, and also juvenile works, aeronauticsl fiction dealing primarily with the World War I era, and concluding with materials about the American lunar landing.

With a total of more than 20,000 items, the Gimbel Library is a comprehensive record of aersnautical history. To this collection we have added approximately 500 rare books that were already in the Academy Library collection and about 400 items cionated by Richard Upjohn Light. Items are also being added by purchase and excharge. These additions contribute to the goal of making the Ginbel Library detinitive in the era prior to heavier-than-air flight. A printed vitalog is a goal for the future.

Colonel Richard Gimbel (1898-1970) was a grandson of the Gimbel department stores founder. He served in Europe with the Army Air Forces during World War II, and concluded his military career as Professor of Air Science at Yale University, retiring as an Air Force colonel in 1953. He subsequently was made Surator of Aeronautical Literature at Yale University Library and served in this capacity until his death.

A Gimbel family tradition of active and enthusiastic support of philanthropic and cultural activities was carried on by Colonel Gimbel throughout his life. He was also a noted bibliophile. In addition to his aeronautical history resources, he assembled major collections concerning Charles Dickens, Edgar Allan Poe, and Thomas Paine. There were other minor gatherings as well. The aeronautical collection was transferred to the Air Force Academy Library in 1971, and is being cataloged for use by faculty, cadets, and other scholars. 



\section{DRGANIZED WRITING}

Too many writers start throwing ink before they know what to ain at. When you write, start with a clear sense of your purpose and audience, and arrange your ideas so you gुet to the point fast. Then write effective paragraphs and sentences.

\section{Establish Your Purpose and Audience}

You'll save time and rewrite less if you plan before you pick up a pen or start to dictate. In the planning stage, analyze your audience in light of your purpose by answering these questions:

What is my purpose?

Who are my readers?

What are their interests?

How much do they know already?

What will make it easy for them to understand or act?

You'll discover ideas as you write, but you'll wander less by keeping the answers to these questions in mind.

\section{Start Fast, Explain as Necessary, Then Stop}

Timid writing creeps up on the most important information. First comes background, then discussion, and finally the so-what. With luck, the main point follows a sign such as therefore, consequently, or due to the above. This slow buildup isn't chaotic; it enacts the way writers inform themselves. But the pattein isn't efficient, either. From the perspective of readers, it's the clue-by-clue pattern of mystery stories.

Your writing should follow the newspaper pattern. Open with the most important information and taper off to the least important. I void mere chronology.

To find what to put first, think about the one sentence you'd keep if you could keep only one. Many letters and memos are simple enoush to have such a key sentence, which should appear by the end of the first paragraph. The strongest letter highlights the main 
point in a one-sentence paragraph at the very beginning. Put requests before justifications, answers before explanations, conclusions before discussions, and sum naries before details.

Sometimes, as in a complex proposal or a reply to various questions, you may have many key points. They would overload the first paragraph if you tried to jut them all there. In these cases, start with a general statement of purpose.

Here are some good beginnings:

We inspected the Directorate of Administration on 24 January 1984. Its overall performance $:$ as satisfactory. Special-interest areas were also satisfactory....

We request authorization to hire a full-time clerk typist or reassign one from the word-processing center. ...

This memorandum summarizes how we are planning the first step toward your goal of reorganizing the Air Force Reserve....

Sgt Frank Martin did a superb job during our recent engine change. . . .

Delay your main point to soften bad news or to introduce a controversial proposal. But don't delay routinely. Readers, like listeners, are put off by people who take forever to get to the point. In most cases, plunge right in.

To end most letters, just stop. When writing to persuade rather than just to inform, end strongly-with a forecast, appeal, or implication that activates the reader to do something. When feelings are involved, exit gracefully-with an expression of good will. When in doubt, offer your help or the name of a contact.

\section{Use More Headings}

Any document longer than three pages probably needs headings, so that readers can follow at a glance. Even a one-page letter can benefit from headings when topics vary widely. Be informative; avoid relying on headings that use one or two vague words.
For: Procedures
Try: How to Complete DoD Form 78
For: Use of Contractors
Try: How Much Contractors May Charge

\section{Write Effective Paragraphs}

Keep paragraphs short. Cover one topic completely before starting another, and let a topic run for several paragraphs if necessary. But keep each paragraph down to roughly four or five sentences. Long paragraphs will divide where your thinking takes a turn. 
Now and then use a one-sentence paragraph to highlight an important idea, such as the main point of a letter.

Use more lists. Look for opportunities to divide paragraphs into lists. This technique is especially important for staff papers and directives. As you can see, lists--

Add white space for easy reading,

Show levels of importance,

Simplify-

Initial review,

Later revision.

Just remember to avoid dividing a paragraph into more than the three levels shown here. If you use too many lists within lists, readers will lose sight of the overall structure.

Take advantage of topic sentences. A paragraph may need a topic sentence--a generalization explained by the rest of the paragraph. Then again, it may not. The decision to use a topic sentence is among a writer's many judgment calls. A short paragraph announcing the time, place, and agenda of a meeting might begin with, "Here are details about the meeting." Yet such a topic sentence is probably unnecessary, for readers can follow the writer's thinking without it.

But suppose you're writing a report un ways to protect a particular military facility from attack. Your ideas are complex, and the evidence needed to inake them clear and convincing is considerable. So your paragraphs are likely to run longer and use more topic sentences than is the case in letters. Here's a model:

Because so :nuch of the complex borders the river, its waterfront is especially vulnerable to attack. The naval station and the shipyard next to it have 1.5 miles of waterfront on the river's north bank. Toirether they have 13 dry docks and piers. Two piers are used to load fuel. Most of the piers extend to within 100 yards of the center of the river's main ship channel; and the river itself is only 900 yards at its widest.

The first sentence of the sample gives the paragrash a bull's eye. Because we know early where the facts are headed, the paragraph inspires confidence. A lesser writer inisht ilave left out the topic sentence or put it elsewhere in the paragraph or claimed more than the facts support. Be alert to the advantages of topic sentences, for they help shape masses of information. Without the $\mathrm{n}$, so me para sraphs make readers shrug and say, "So?"

\section{Write Disciplined Sentences}

So far we've talked ajout organizins letters and paragraphs so they call attention to important ideas. Now here are some important ways to avoid sentences that mumble: subordinate minor ideas, use more parallelism, place ideas deliberately, and try saine inini-sentences. 
Subordinate minor ideas. Besides clarifying the relationship between ideas, subordination prevents overusing and--the weakest of all conjunctions.

For: The base exchange at Peterson AFB uses a similar contractor service and saves its customers about 15 percent.

Try: By using a similar contractor service, the base exchange at Peterson AFB saves its customers about 15 percent.

For: The revised travel-allowance tables have been mailed to all units and are effective 1 October.

Try: The revised travel-allowance tables, which have been mailed to all units, are effective 1 October. (stresses date)

Or: The revised travel-allowance tables, which are effective 1 October, have been mailed to all units. (stresses mailing)

Use more parallelism. Look for opportunities to arrange two or more equally important ideas so they look equal. Parallelism saves words, clarifies ideas, and provides balance. The first words of the series should use the same part of speech (verbs in the previous sentence).

For: The symposium is a forum for the dissemination of information and is not intended to establish standards.

Try: The symposium is a forum for sharing information, not for setting standards.

For: Effective 1 October, addressees will be require 3 to utilize the cost accounts contained in the attachment. Addressees will cease reporting against cost accounts 1060,2137 , and 2340.

Try: On 1 October, start using the cost accounts in the attachment and stup using cost accounts 1060,2137 , and 2340.

Place ideas deliberately. Start and finish a sentence any way you like, but keep in mind that ideas gain emphasis when they appear at either end. To mute an idea, put it in the middle.

Maintenance time may have to increase if more structural problems develop. (mutes increased time)

If more structural problems develop, maintenance time may have to increase. (stresses increased time)

For: I would like to congratulate you on your selection as our Employee of the Month for June.

Try: Congratulacions on your selection as our June Employee of the Month. 
Try some mini-sentences. An occasional sentence of six words or less slows down readers and emphasizes ideas. The principle is illustrated in this nex: example from a general's memo to his staff.

I can get more information from the staff if each of you gives me less. Here's why. In a week, about 110 staff actions show up in my in-box. I could handle these in a week if all I did was work the in-box. Yet about $70 \%$ of my time in the headquarters goes not to the in-box but to briefings. I could handle that dilemma, too-by listening to briefings and thinking about staff papers at the same time. I don't.

Look for opportunities in your own writing to use mini-sentences. They'll give it variety.

For: I apologize for not answering your letter sooner, but an extended TDY kept me away from my desk for three weeks.

Try: I should have answered your letter sooner. I apologize. An extended TDY kept me away from my desk for three weeks. 


\section{SPOKEN WRITING}

Make your writing as formal or informal as the situation requires, but do so with language you might use in speaking. This isn't a call to copy every quirk of speech down to grunts and ramblings. And, granted, some people speak no better than they write. Still, because readers "hear" writing, the most readable writing sounds like people talking to people.

To make your writing more like speaking, begin by imagining your reader is sitting across from you. Then write with personal pronouns, everyday words, contractions, and short sentences. Together with questions, good tone, and concrete language, these techniques are the best of speaking.

\section{Use Personal Pronouns}

Though you needn't go out of your way to use personal pronouns, you mustn't go out of your way to avoid them. Avoiding natural references to people is false modesty. Whether you're a senior official or a subordinate, follow these principles:

1. Use we, us, our when speaking for your organization.

2. Use I, me, my when speaking for yourself.

3. Use you, stated or implied, to refer to the reader.

Multiplied across an entire letter, roundabout sentences like the next examples do severe damage. We would be laughed out of the room if we talked that way. Ordinary English is shorter, clearer, and just as official:

Not: Conceivably, funding constraints for this year will exceed in severity the financial scarcities that have been anticipated.

But: We may have less money this year than we anticipated.

Not: The Naval Facilities Engineering Command, by reference (a), forwarded its draft master plan for the Washington Navy Yard to the Naval Supply Systems Command for review and comment. The following comments apply.

But: In response to reference (a), here are our comments on your draft master plan for the Washington Navy Yard. 
Not: It is neressary that the material be received in this office by June 10 .

But: We need the material by June 10 .

Or: The material must reach us by June 10 .

It is and this command complicate the next example. They force readers to put back the pronouns the writer took out. To make matters worse, the first it is refers to the reader, while the second refers to the sender.

Not: If it is desired that Marines be allowed to compete for positions on the pistol team, this command would be happy to establish and manage team tryouts. It is recommended that tryouts be conducted soon to ensure. ....

But: If you allow Marines to compete for positions on the pistol team, we would be happy to establish and manage the tryouts. We recommend that tryouts start soon to ensure....

Military writers can profit from an axiom of business writing known as the "you" attitude. It's a matter of showing greater concern for the reader than the writer by using you more than 1 or we. Better to say "the service you receive" than "the service we provide." Keep this distinction in mind, and when you have a chojce, show that you see things from your reader's perspentive by putting the emphasis on "you."

Can you overuse personal pronouns? In a few instances, yes. For example, you can use so many pronouns - that readers lose sight of what the pronouns refer to. Besides, some subjects don't lend themselves to pronouns; the description of a plane's structure isn't likely to include people. Also, criticism hurts fewer feelings if delivered impersonally. "Nothing has been done" avoids the direct attack of "You have done notining." Finally, if we $\mathrm{Cr}$ I opens more than two sentences in a row, the writing becomes monotonous and may suggest self-centeredness. Still, military writers have a long way to go beiore overuse of pronouns is a problem. Most of us will benefit from using more natural references to people.

\section{Talk to One Reader When Writing to Many}

When you're writing to many people but none of them in particular, create in your mind a typical reader. Talk to that reader by using you and your, stated or implied. Only one person reads your writing at any one time, so the most readable writing speaks directly to one reader.

Not: All addressees are requested to provide inputs of desired course content.

But: Please send us your recommendations for course content.

Not: It is requested that all employees plonning to take leave in December fill in the enclosed schedule.

But: If vou plan to take leave in December, fill in the enclosed schedule. 
When you write directives, look for opportunities to talk directly to a user. Procedures, checklists, or other how-to instructions lend themselves to this cookbook approach. Imagine someone has walked up to you and asked what to do. The following example is from an instruction that repeated the duty officer dozens of times:

Not: The duty officer will verify that security responsibilities have bien completed by putting his/her initials on the checklist.

But: When you complete the inspection, initial the checklist.

\section{Rely on Everyday Words}

The complexily of military work and the need for precision require some big words. But don't use oig words when little ones will do. People who speak with small words ften let reedlessly fancy ones burden their writing. On paper help swells to assista pay to remuneration, and visit to visitation. The list goes on, and so does the damag $f$ om word inflation.

Do you remember the dude in those old Western movies who overdressed to impress the folks at the ranch? Overdressed writing fails just as foolishly. Here are some commonly overdressed words.

$\begin{array}{ll}\text { Not } & \text { But } \\ \text { commenre } & \text { start } \\ \text { facilitete } & \text { help } \\ \text { optimum } & \text { best } \\ \text { promulgate } & \text { issue } \\ \text { utilize } & \text { use }\end{array}$

Prefer shørt, spokan transitions over long, bookish ones. Save long transitions for variety. By preferring short ones, you help set an ordinary tone for the rest of what you say. (And, yes, you can start sentences with conjunctions.)

$\begin{array}{ll}\text { Not } & \text { But } \\ \text { consequently } & \text { so } \\ \text { however } & \text { but } \\ \text { in addition } & \text { also } \\ \text { nevertheless } & \text { still }\end{array}$

Avoid legalistic lingo. Let a regulation's number or a letter's signature carry the authority instead of trying to put that authority in your language. Write to express, not to impress.

\section{Not}

E:foresaid

heretofore

herewith is

the undersigned
But

the, that

until now

here is

I 
All writers try, impress readers. but the best do it through language that doesn't call attention to itself. Size of vocabulary is less important than skill in manipulating the words jou already know. See Appendix A for a list of simpler words and phrases.

\section{Use Some Contractions}

Contractions link pronouns with verbs (we'd, I'll, you're) and make verbs negative (don't, can't, won't). They're appropriate for all but the most formal writing situations. Yet even when your final product will be a formal reprimand, for example, you can use contractions in drafts to help you write naturally.

The point is that if you're comfortable with contractions, your writing is likely to read easily, for you'll be speaking on paper. And because the language is clear, you're more likely to spot holes in your thinking that need to be filled.

If contractions seem out of place, you may need to deflate the rest of what you say. In the next sentence, something has to go, either the opening contraction or the inflated language that follows: "It's incumbent upon all personnel to effect energy savings." Written naturally, the sentence might read, "It's your job to save energy."

\section{Keep Sentences Short}

For varifty mix long senterces and short ones, but average under twenty words. Though short ser.'ences won't guarani se clarity, they're usually less confusing than long ones. You needn't count every word. Try the eye test: average under two typed lines. Or try the ear test: read your writing aloud and break up most of the sentences that don't end in one breath. In the next example, we first break the marathon sentence into manageable units and then make the writing sound like zpeaking.

Not: It is requested that attendees be divided between the two briefing dates with the understanding that any necessary final adjustments will be made by DAA to facilitate equitable distribution. ( 29 words)

Uh: It is requested that attendees be divided between the two briefing dates. Any necessary final adjustments will be made by DAA to facilitate squitable aistribution. (12, 13 words)

But: Send half your people on one day and half on the other. DAA will make final adjustments. (12, 5 words)

\section{Ask More Questions}

A request gains emphasis when it ends with a question mark. Do you hear how sf :en a question is? Look for opportunities to reach out to your reader:

Not: Request this headquarters be notified as to whether the conference has been rescheduled.

But: Has the conference been rescheduled?

$$
I I-10
$$


Not: In an effort to improve the cost of office copier operation, it is requested your firm complete the attached form relating to office copiers which you would propose to rent/lease.

But: Would you let us know on the accompanying form what you charge to rent and lease your copiers?

\section{Listen to Your Tone}

Speakers have gesture, voice, and movement t', help them communicate. Writers have only words on paper. Recognize your disadvantage as a writer and remember to pay special attention to tone.

Tone-a writer's attitude toward the subject or readers-causes relatively few problems in routine "rriting. The more sensitive the reader or issue, however, the more careful we must be to promote good will. Tactlessness in writing suggests clumsiness in general. When feelings are involved, one misused word can make an enemy.

Imagine you are a reservist who has asked to stay on active duty even though you have a serious illness. How does the following answer strike you?

Because you have failed to pass the prescribed physical examination, you will be removed from active duty.

Failed? Removed? These words hint at crime and punishment. To avoid such tactlessness, the tone should be positive.

\section{Negative}

Opportunity is limited.

Stop writing badly.

Don't use the small hoist.

The cup is half empty.

\author{
Positive \\ Competition is keen. \\ Start writing well. \\ Use the big hoist. \\ The cup is half full.
}

The positive approach removes some of the sting from the reservist's answer. Here's a possibility:

Given the results of your physical examination, we must transfer you to the Retire 1 Reserve.

The structure of the letter was better than the wording of the "failed" sentence. The letter opened by acknowledging the favorable endorsements that accompanied the request to stay on active duty, and it closed by thanking the reservist for his years of service. This tactful arrangement helped to soften the bad news.

Now imagine you've asked for more time to complete a correspondence course. Here's the last sentence of the letter that turns you down:

If we can be of further assistance, please do not hesitate to write.

Beware of rubber-stamp endings such as the one you just read. They don't improve good letters or save bad ones. To the reader whose request has been denied, further assistance 
promises further disappointment. The closing sentence should be dropped entireiy or tied to the rest of the letier with positive language:

This setback aside, we hope you will take advantage of other correspondence courses availabie to you.

In all fairness to the writer, the letter did explain the denial in enough detail to avoid any hint of a brush-off. Most no answer's need some explanation. Yes answers need little explanation because readers get what thiey want.

\section{Be Concrete}

Without generalizations and abstractions, lots of them, we would drown in detail. We sum up vast amounts of experience when we speak of dedication, programs, hardware, and lines of authority. But such abstract language isn't likely to evoke in a reader's mind the same experiences it evokes in a writer's. Lazy writing overuses such vague terms. Often it weakens them further by substituting adjectives for examples: immense dedication, enhanced programs, viable hardware, ind responsive lines of authority.

If you write, "The solution to low moraie and poor discipline is good leadership," your readers may feel warm all over. But until you point out some specific behavior meant by low morale, poor discipline, and good leadership, neither you nor your resders can tackle the problem. Similarly, don't use a general word if the contexi allows for a specific one. Be as definite as the situation permits.

$\begin{array}{ll}\text { For } & \text { Try } \\ \text { aircraft } & \text { plane } \\ \text { plane } & \text { F-16 } \\ \text { improved costs } & \text { lower costs } \\ \text { enhanced method } & \text { faster method? cheaper method? }\end{array}$

Vague, high-sounding language also weakens job descriptions. Someone is said to "assist and advise in the organization management aspects of manpower management." Another "serves as a system proponent to transition from current capabilities to architecural projections." But what do these people really do? After all, a person who "serves as a direct interface with interstate commerce" may be only a highway flag holder.

Performance evaluations suffer when writers make extravagant, unsupported claims. Someone actually wrote this next example, and someone else has it ticking in his files.

Engaged in an assignment of a highly complex and technical nature, Sgt Anderson has molded on-the-job experience, diligence, and perseverance to a point where his seniors and supervisors can inevitably afford credence to his work anc the conclusions he derives therefrom.

An effective evaluation shows what a person did and how well he or she did it. It's concrete enough to inspire confidence in the writer's judgment about the ratee's performance and potential. 


\section{OMNESE WITTING}

Concise writing includes only those ideas that readers need, and it gives those ideas no more words than they deserve. Careful audience analysis and a willingness to be hard on yourself are essential for conciseness. Have you included too much background? Do excessive details bury your point? Are you keeping an irrelevant idea just because it sounds ever so fine?

You can say too little, of course, and not persuade your readers that a certain problem is serious or that your solution is worthwhile. Sometimes simple courtesy requires bulk; a one-sentence letter of praise is just too abrupt. But the point remains: the best writing, like the best machinery, has no unnecessary parts.

Don't be overly concerned about conciseness when you are getting your ideas on paper. If you try to create and edit at the seme time, you may bog down in detail and lose sight of your point. When you polish your writing, though, look for wordiness everywhere. Question the need for every paragrapin, every sentence, every word. The longer you take to say things, the weaker ycu come across and the more you risk blurring important ideas. In the war aguinst wordiness, the best weapon is a writer's ruthlessness. Now here are some common forms of wordiness that are easy to sp if and avoid:

\section{Avoid rit is" and "there is"}

No two words hurt military priting more than it is. They stretch sentences, delay meaning hide responsibility, and encourage passive verbs. Unless it refers to something mentioned earlier, avoid it is. Spare only spoken expressions such as "it is time to ..." or "it is hard tn ..." and an occasional pointing expression such as "it is your job to ..." (not someone else's).

\section{Not}

it is requested

it is my intention

it is necessary that you

it is apparent that

it is the recommendation of this office that

\section{But}

we request, please

I intend

you need to, you must

clearly

we recommend 
Not: It is mandatory that all personnel receive flu vaccinations.

But: All personnel must receive flu vaccinations.

Not: It is requested that all badges be surrendered upon departure of your group from the restricted area.

But: Return all badges when your group leaves the restricted area.

Like it is constructions, forms of there is make sentences start slowly. Don't write these delayers without first trying to avoid them.

Not: There will be a meeting of the Human Relations Council at 1000 on 26 July in the main conference room.

But: The Human Relations Council will meet at 1000 on 26 July in the main conference room.

Not: There are two alternatives offered in the report.

But: The report offers two alternatives.

\section{Prune Wordy Expressions}

Wordy expressions don't give writing impressive bulk; they clutter it by getting in the way of the words that carry the meaning. In order to and in accordance with, for example, are minor ideas that don't deserve three words. Here are some repeat offenders.

Not

for the purpose of

in accordance with

in order to

in the event that

in the near future

be advised

in the process of

is responsible for

the provisions of

the use of
But

for, to

by, following, under

to

if

shortly, soon

Wordy expressions dilute the next examples. Extended across a letter or report, the savings from cutting such bloated language are considerable.

Not: In accordance with the new regulation, you may pay the claim with a check in the amount of $\$ 300$.

But: Under the new regulation, you may pay the claim with a check for $\$ 300$. 
Not: In the event that this offer is satisfactory, be advised your written acceptance must reach us before May 11.

But: If this offer is satisfactory, your written acceptance must reach us before May 11.

Not: We are in the process of revising our form letters in order to make them more readable.

But: We are revising our form letters to make them more readable.

\section{Free Smothered Verbs}

Make your verbs do more work. The most important word in a sentence is the verb, the action word, the only word that can do something. Weak writing relies on general verbs, which take extra words to complete their meaning. When you write a general verb such as make or give, check to see whether you can turn a nearby word into a specific verb.

Not: This directive is applicable to everyone who makes use of the system.

But: This directive applies to everyone who uses the system.

Not: The committee held a meeting to give consideration to the proposal.

But: The committee met to consider the proposal.

Not: We will conduct an investigation into the incident before making a decision.

But: We will investigate the incident before deciding.

To be deserves special attention. It's the most common verb in English and the weakest. Though we need it often, often we don't. Cut down on your use of to be in any of its forms: am, is, are, was, were, be, being, been.

\section{Shun "the -ion of "and "the -ment of}

Words ending in -ion and -ment are verbs turned into nouns. Whenever the context permits, change these nouns to verb forms. By favoring verb forms, your sentences will be shorter and livelier.

Not: Use that format for the preparation of your command history.

But: Use that format to prepare your command history.

Not: The settlement of travel claims involves the examination of orders.

But: Settling travel claims involves examining orders.

Or: To settle travel claims, we examine orders. 


\section{Cut Doublings}

As the writer, you may see some differences between advise and assist, interest and concern, or thanks and gratitude. But your readers won't. Repeating a general idea can't make it any more precise. Simple subtraction will overcome doublings such as these:

Not: We must comply with the standards and criteria for controlling and reducing environmental pollution.

But: We must comply with the standards for reducing environmental pollution.

Not: The Department of Defense has developed plans for an orderly and integrated system of executive and management advancement.

But: The Department of Defense has developed plans for a system of executive advancement.

\section{Prevent Hut-2-3-4 Phrases}

Though you should cut needless words, sometimes you can go too far. Avoia hut-2-3-4 phrases-long clots of nouns and modifiers. Readers can't tell how the parts fit together or where they all will end. We must live with some established hut-2-3-4 phrases such as Air Traffic Control Radar Beacon System, but you can keep them out of whatever you originate by adding some words or rewriting entirely.

Not: the Board of Inspection and Survey service acceptance trials requirements

But: requirements by the Board of Inspection and Survey for service acceptance trials

Not: trainirig needs planning summary survey

But: survey of training needs for the planning summary

\section{Avoid Excessive Abbreviesing}

Excessive abbreviating is another common form of false economy. Use abbreviations no more than you must with insiders, and avoid them entirely with outsiders. Spell out an unfamiliar abbreviation the first time it appears, like this:

Training and Doctrine Command (TRADOC)

If an abbreviation would appear only twice or infrequently, spell out the term every time and avoid the abbreviation entirely. Put clarity before economy. 


\section{ACTHEE WIAHTHNE}

Passive writing is wordy, romdabout, and sometimes downright confusing. To avoid this infeetious disease, learn how to: spot passive verbs and make them active. Most of your sentences should use a who-does-what order. By leading with the doer, you automatically will avoid a passive verb.

Doctor: When did you:first notice your use of verbs in the passive voice?

Patient: The utilization was first noticed by me shortly after the military was entered. A eivillin agency has been joined by my brother. The same condition has been remarked on by him.

Doctor: Did you know that most of the verbs we speak with are active? So are most of the verbs:in newspapers and magazines, the kinds of writing: we like to read:

Patient: Well, it is believed by me that many verbs are made passive by military writers. In the letters and directives tin.t have been prepared by this speaker, passive verbs have been utilized extensively. Are problems caused?

If you heard the unnatural sound of the patient's passives and know how to lead with doers, you needn't read on. But the following technical discussion may be helpful.

\section{Learn the Symptoms of Passive Voice}

A verb in the passive voice uses any form of to be plus the past participle of a main verb:

$$
\text { am is are was were be being been }
$$

a main verb usually ending in -en or -ed

Unlike sentences with active verbs, sentences with passives don't need to show who or what has done the verb's action. If a doer appears at all, it foll.ws the verb. But most passives in military writing just imply the doer, a severe problem when the doer isn't clear from the context. Passive verbs look like the following underlined words: 
Ex: As a result of what has been learned, it is desired that additional equipment testing:be made.

(Be made.is passive. The past particple of to make is irregular.)

Fix: Two units of blood were ordered-for an emergency patient whose hematoesit had fallen below 20 percent.

(Had fallen is active. Fad isn't a form of to be. Besides, what did the falling?

\section{Know the Three Cures}

Put a doer before the verb:

Not: The part must have-betoken by the handlers.

But: The handlers must have broken the part.

Not: The lequests:must be approved: (By whom?)

But: The-supervisor must appreve the requests.

Not: Completesuniforms must be worn-by alligersonnel.

But: All personnel must wear complete-uniforms.

Or: Wear complete uniforms.

Drop part of the verb:

Not: The resul are listed in the attaenment.

But: The results are in the attaciment.

Not: Then she was transferred to-Maxwell AFB.

But: Then she transfierred to Maxwell AFB.

\section{Change the verb:}

Not: Letter formats areshown in the correspondence manual.

But: Letter formats appear in the capcespondence manual.

Not: The replacement has not been reived yet.

But: The replacement has not arrived yet. 


\section{Write Pa frely only for Good Reason}

IfFer and one the betion:- This situation may occur if the doer is unknown, unimportant, obivious,

Presionts are elected every four years. (doer obvious)

Thept was shipped on 1 June: (doer unimportant, perhaps)

Ciristmashasbeen schedufied as-a work day. (doer better left unsaid)

Now and then you may want to write a passive sentence that names the doer. The situation may oecur when zouneed-a transition from one topic to another. The following semenee would shift a discussion from individual habit to group inertia:

Writing improvement as dcubly difficult when individual habit is reinforced by group inertia.

Now and then, a passive sentence that names the doer is appropriate if the rest of the paragraphis about the receiver of the verb's action. The following sentence might work in a paragraphabout a general.

Then the-general was hit by a falling limb.

Finally, for variety or stateliness, you may want the slow procession of a passive sentence such as this one on a monument at the Air Force Academy:

Man's flight through life is sustained by the power of his knowledge.

When in doubt, write actively, even though the doer may seem obvious or whatever. You will write livelier sentences (not, livelier sentences will be written by you).

\section{Practice on These Bzampte:}

The following paragraph comes irom a letter that proposes to expand a Scheduled Airline Ticket Office (SATO). Find to passives and try to make them active. Then check yourself against the revision.

During that time period, a total of $\$ 644,000$ was expended in the issuance of government transportation requests (GTRs) for air travel. It is estimated by SATO that an additional $\$ 10,000$ per month wouid be generated through casual travel. A summary of the GTR revenue by month is provided in attachment 1.

Here is a sentence-by-sentence revision of the passive paragraph:

During that time period, a total of $\$ 644,000$ was expended in the issuance of government trasportation requests (GTRs) for air travel. 
We can cut 19 percent from the passive sentence above just by shortening during that time period to during that time and by omitting a total of. No writer has any excuse for not performing such simple subtraction. To avoid the passive was expended, we don't have to know who or what did the spending. The core idea is this: "During that time, government transportation requests (GTRs) for air travel totaled $\$ 644,000$." Now the verb carries more of the meaning, $\$ 644,000$ appears in a stronger place, and the sentence is slimmer by 43 percent.

It is estimated by SATO that an additional $\$ 10,000$ per month would be generated through casual travel.

This sentence is easy to improve because doers follow both passive verbs. "SATO estimates that casual travel would generate an additional $\$ 10,000$ per month." Though active now, the sentence still needs work. We can shorten generate to add, an additional to another, and per to a. For clarity, casual travel can become off-duty travel. These small improvements add up: "SATO estimates that off-duty travel would add $\$ 10,000$ a month."

A summary of the GTR revenue by month is provided in attachment 1.

Though the sentence would be shorter if we simply dropped provided, the weak is would remain. Better to reshape the sentence; "Attachment 1 provides a summary of the GTR revenue by month." But provides a summary is a smothered verb for summarizes. So the best improvement is this: "Attachment 1 summarizes the GTR revenue by month." Here is the passive or iginal again, followed by the active version:

Passive: During that time period, a total of $\$ 644,000$ was expended in the issuance of government transportation requests (GTRs) for air travel. It is estimated by SATO that an additional $\$ 10,00$ per month would be generated through casual travel. A summary of the GTR revenue by month is provided in attachment 1. (50 words)

Active: During that time, government transportation requests (GTRs) for air travel totaled $\$ 644,009$. SATO estimates that offJuty travel would add $\$ 10,000$ a month. Attachment 1 summarizes the GTR revenue by month. (31 words)

The following letter, from an inspector general, suffers from epidemic passives and other problems. On a separate sheet of paper, rewrite the letter to make it organized, spoken, concise, and active.

Attachment 1 is forwarded for review and comment as to concurrence or noncurrence with the recommendations of the subject inspection. Only those recommendations requiring action are forwarded. Comments are requested by 7 June in order thet approval and implementing can be taken. Recommendations will stand as written if concurrence is not nrovided by the above date.

Status reports or comments concerning actions completed or in progress are not to be submitted at this time. Guidance on status reporting will be provided at a later date. ( 85 words) 
Here's our version (you may have come up with a better one).

Please concur or nonconcur with the inspection recommendations in attachment 1. To consider changes to these recommendations, we must have your comments by 7 June.

Don't send status reports about actions completed or in progress.

Guidance on these will reach you later. ( 40 words)

The second sentence of the original is unnecessary. Elsewhere in the original the writing is swollen: provided and submitted for sent, in order that for so, and at a later date for later. But the worst damage comes from the seven untouched-by-human-hands passives. They force readers to pause and figure out just who is supposed to do what. The revision avoids the passives by talking directly to a typical reader. Note the personal pronouns, contractions, and please.

Please, the first word of the active version, is a sonvention of modern writing (and speaking) that helps avoid many roundabout constructions. "Please send us two blivets" is far more efficient than "it is requested that two blivets be sent to this command." Real men-and women-do say "please." 
Executive Writing, a half-day presentation, is available to Department of Defense units that provide audiences of at least 100 officers and civilian equivalents. For details, write or phone-

Department of English

U. S. Air Force Academy

Colorado Springs CO 80840-5871

AUTOVON $259-3930$

Commercial (303) $472-3930$ 
Appendix A

\section{SIMPEER WORDS AND PHRASES}

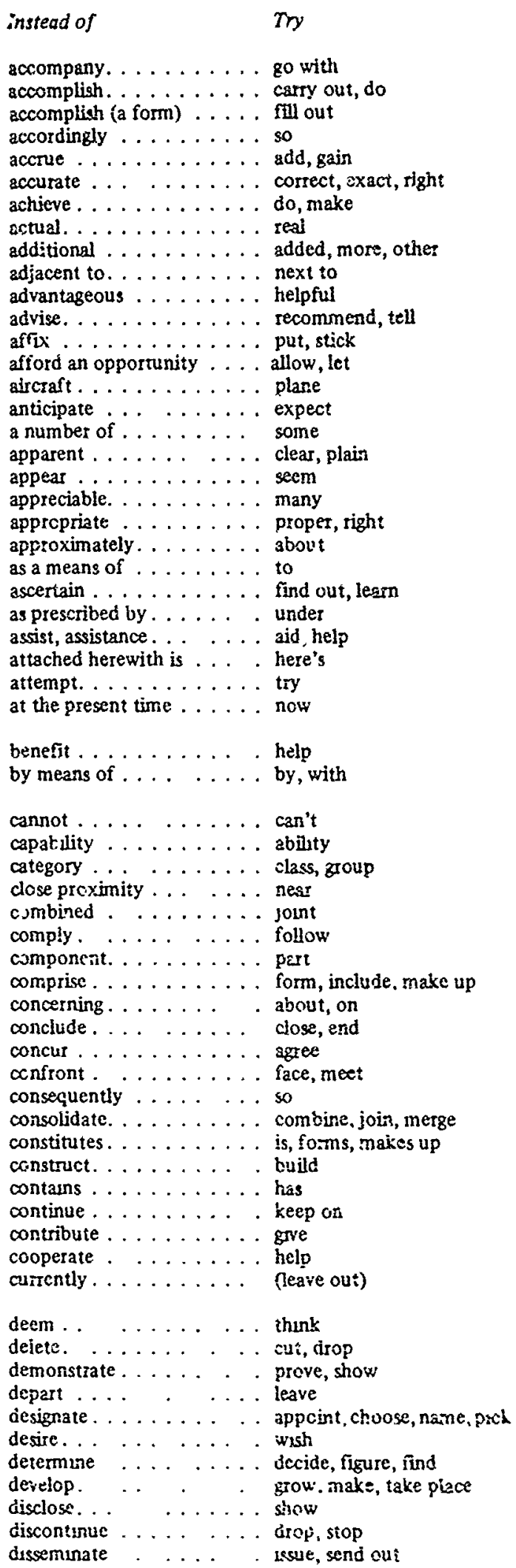

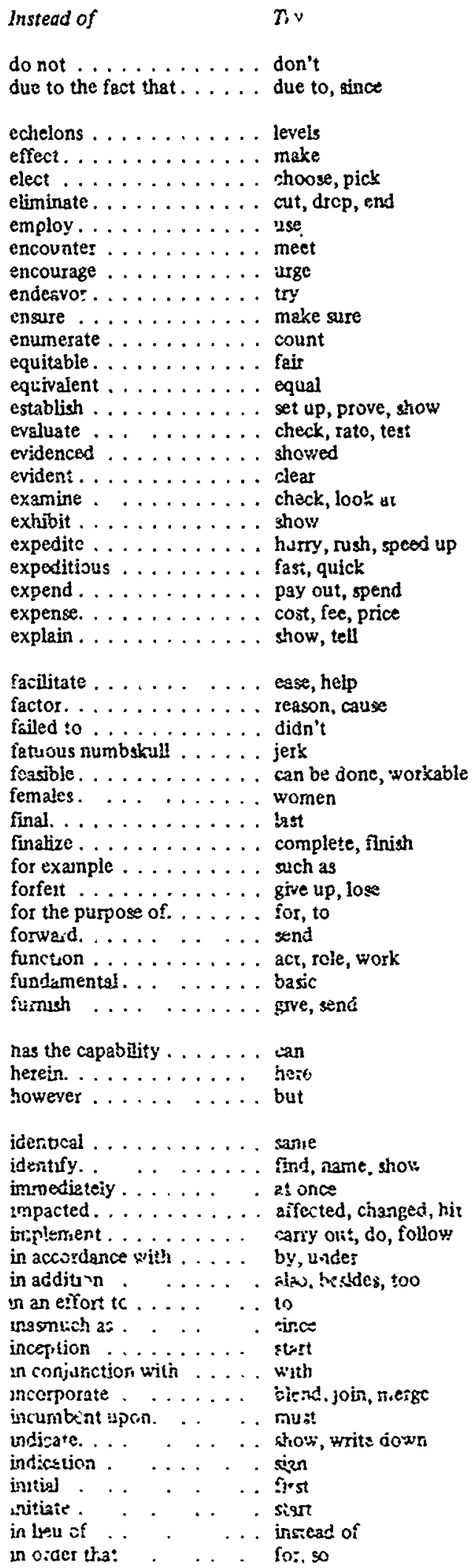




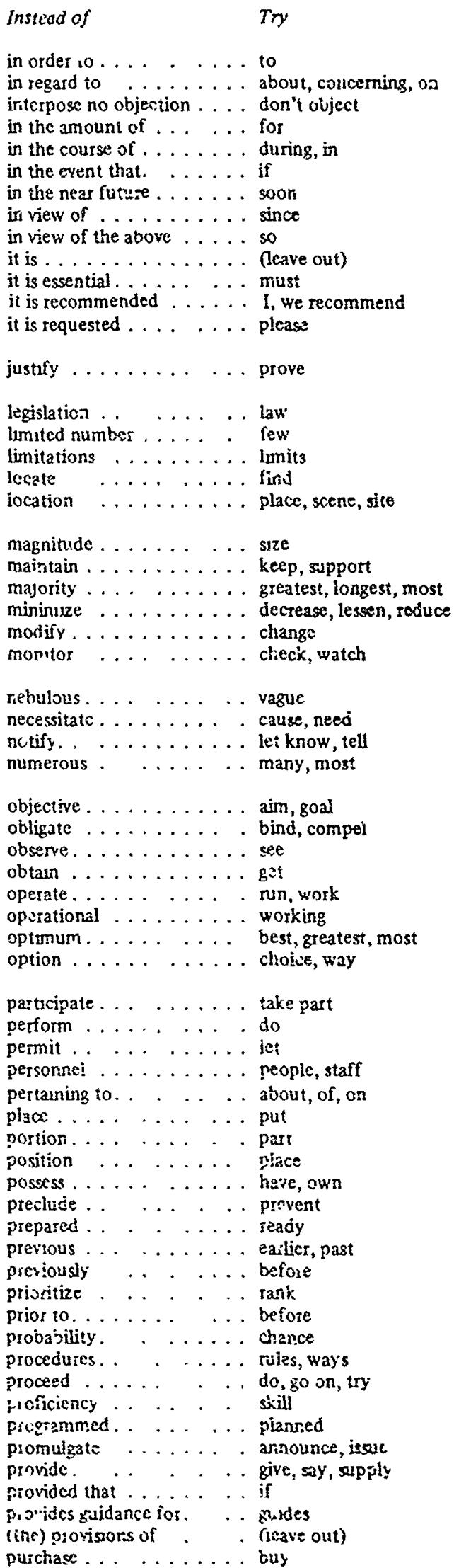

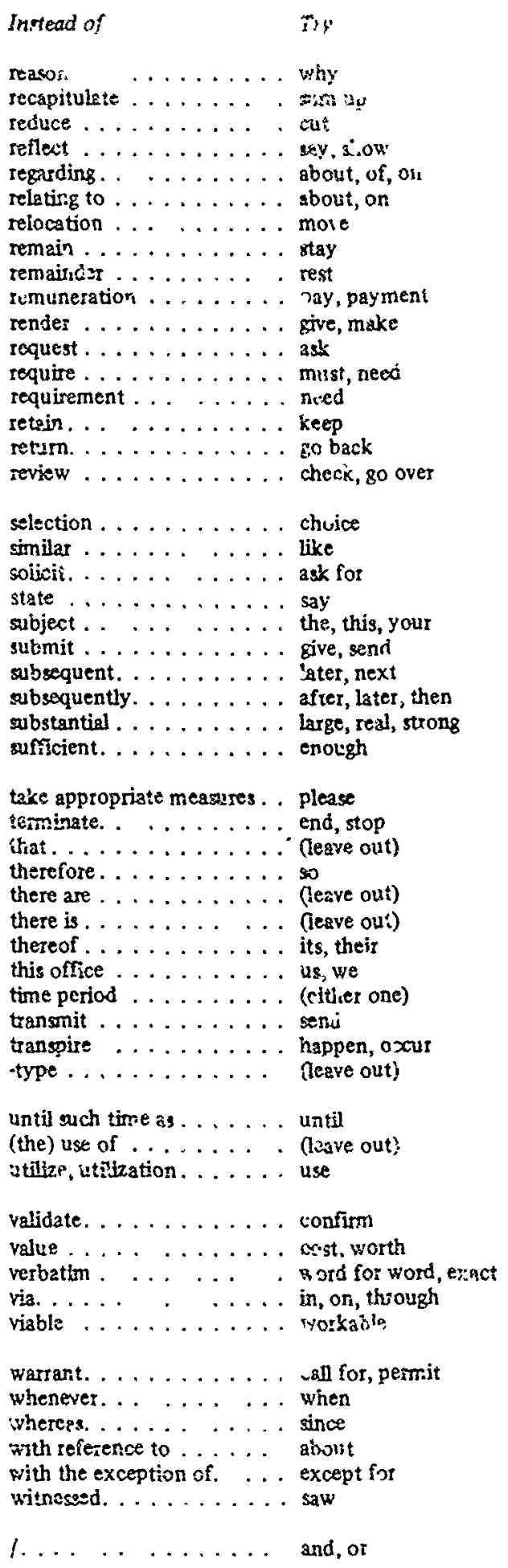


Apperdix $B$

\section{GOMPLRTED STAPE WORK}

Here are two testimonials on how to write ior a busy boss. The first romes from an anonymous university acministator. The second is part of a memo by Armv Cinsial Donn A. Starry to his staff. Tagether the statements algw ior 'horough legwo.': and compact paperwork.

Compieted ste.fi work consists of studying, a problem and presentir.? its solution in such $i$ way that the President need only indicate his approval ur aisapproval of the completer action. The words comp'eted action are emphasized because the more difficuit a problem is, the more the tendency is to present the problem to the President in fiecerica: fashion. It is a siaff member's duty to work out details, no matter how perplexing they may be.

It is so easy to ask the president whet to do, and it appears so easy for him to answer. Resist that impulse. You wili sliciumb to it only if you Jo not know your job. It is your iob to tell the president wirat he ought to do, not to ask him what you ought to do. HE NEEDS ANSWERS, NOT QUESTIONS. Your job is to study, write, restucy and rewrite until you have evolved a single proposed $a c^{2}$ ion- - the bes ${ }^{4}$ one of all you have considered. The president merely approves or disapproves. Alternate courses of action are desirable in many cases and should be presented. But you should say which alternative you think is best.

Do you woriy the Prcsident with long explanations and memorznda? inriting \& nemorandum to the President does not constitute completed sta if work, but writin: a memorandum for the President to send to zo renne else does. Your views should be placed before him in finished furm sc that he can make them his views simply by rigning his name. The stateinent should be submitter with supporting cocuments, as approprigie. If you have reached the proper result, the President will usualiy recognize it at once. If he wants comment or explonatior, he will ash for i?.

The theory of completed staff work does not preclude the rough draft, Jut ihe rough draft must not be a half-baked idea. It must be complete in every respect, except that it lacks the required number of copics and may not re neat. Do not use a rough draft as an excuse for shiiting to the Presicent your burden of formulating the action.

The completed staff work theory may result in more work for the siaff member, but it resuits in more l:eedom ior the President. mis is as it should te. Further, it accomplishes two thing:

The President is prctected from half bnker ings, voluminoss merroranda and inmature orai presentat: ms.

The staff member who has an idea to sell can find a marizet nore readily. 
When you have finsineci your stuff work, the fina! test is this: if you wer a the Prssicsent, would you sign the paper you have prepared and stake your professional reputation on its being right? If the answer is no, take it brak and work it over, because it is not yet completed staif work.

I can get more information from the staff if each of you gives me less. Jere's why. In a week, about 110 staif actions show up in my in-box. $i$ could handle these in a week if all I did was : vork the in-box. Yat about $70 \%$ of my time in the heauquarters goes not to the in-box but to briefings. I could handle tlat dilemma, too-by listening to briefings and thinking about staff papers at the same time. I don't. Most of the information I need is in the field. Much of my time must. go there. In Fabruery, for example, I was here six days.

Within those six devs, add 15-20 office calls, a dozen or so visitors, seven social engagements, two or three ceremonies, and 32 telephone calls. These are the realities.

To work the problems of the central battle within the restrictions of the realities, I need less information. But every piece of the less has to be pure. Every piece rinust go through that old filter of need to know, good to know, nice to know. i need the need part, not the "est. You need ts synthesize. condense, strip olit, boil down, distill, abstract -.. like a good newspaper editor.

Here's your challenge: reduce six months of work tc a 10-page package, or a package to a page. or a page to a paragraph, or a paragraph to a sentence, or a sentence to a lew words, or a few words io a model or diagram. I need concepts, Dottom lines, central thenies, summaries; abstracts. Any action officer who can condense accurately is worth ten who run out poopsheets by the pound. My measure of completed staf work is less paper, not more. 


\section{BOORS ABOUT OFFICIAL PRITING}

Contemporary Business Writing by Michael Adelstein. Random House, 1971. A thorough college text that of ers excellent instruction for the working writer.

Effective Writing: A Workshop Course by Internal Revenue Service. Government Printing Office, 1975. ?Stock No, 048-004-01288-0/Catalog No. T22.19/2: iv 93/3). Excellent advice on how to write official letters that are complete, correct, clear, concise and appropriate in tone.

The Elements of Style, 3rd eoition, by William Strunk, Ir., and E. B. White. Macmillan, 1979. These tips on style are sure to improve anyone's writing.

English 3200: A Programed Course in Grammar and Usage, 2nd edition, by Joseph Blumenthal. Harcourt Bra. e jovanovich, 1972. Readers learn gram. mar, punctuation, and sentence structure by progressing through a series of questions and answers.

Handbook of Technical Writing by Charles T. Brusaw, Gerald J. Alred, and Walter E. Oliu. St Martin's Press, 1976. Besides covering the elements of technical reports, this reference text answers hundreds of questions, some of them fussy, on grammar anci punctuation.

Harbrace College Handbook, $8 \mathrm{th}$ edition, by John C. Hodges and Mary E. Whitten. Harcourt Brace Jovanovicn, 1977. A popular reference on grammar and punctuation. Thorough and sensible.

Plain English for Lawyers by Richard C. Wydick. Carolina Acedemin Press, 1979. A lively, practical book for all who care to write the law in readable English. Includes exarcises and answers.

Revising Business Prose by Richard A. Lanham. Charles Scribner's Sons, 1981. Called "a quick self-teaching method of revision for people who want to transiate burearcratic prose, their own or someone else's, in to plain English."

Rudolph Flesch on Business Communication by, you guessed it, Rudolph Flesch. Barnes $\&$ Nobie, 1974. A short, practical book by the leading advocate of spoken writing.

The Fongue and Quili: Communicating to Manage in Tomorrow's Air Foree, Air Force Pampiliet 13-2. Avallable in spring 1985 through base Publications Distrinution offices. This replacement to Guide for Air Porce liriting offers lively instruction cn speaking and writing. Sections on fundamentals and Air Force formats.

The Word: An Associated Press Guide to Good News Writing by Rene J. Cappon. Associated Press, 1982. How to write news stories that are clear, precise, and appealing. Worthwhile for anyone who cares about the attractive use of language. 
APPEMDIX YII

\section{Sources of Inforgation oc wicrocosputers in Libraries}

\section{Conferences}

Library Sof tware and Computer Conference, May 86, Wash D.C.

American Library Association Annual Conferences

Local Data Processing Manageinent Association seminars (DPMA)

\section{Publications}

SMALL COMPUTERS IN LIBRARIES

(monthly, $\$ 24.00$ )

LIBRARY SOFTWARE REVIEW

(bimonthly, $\$ 69.50$ )

MICRO SOFTWARE REPORT

(11 brary edition, $\$ 97.50$ )

Above publications available from: Meckler Publishing 11 Ferry Lane West Westport CT 06880 (203) 226-6967

MICROCOMPUTERS FOR LIBRARIES

(quarterly product review and procurercent guide)

James E. Rush Assoc. 2223 Carriage Road

Po'vell OH $4300 ́ 5$

(614) $881-5949$

\section{Bser Groupa}

IBM PC Library Users' Group

Randy Godiniza

Sutler Library

State Univ College

1300 Elminood Ave.

Burfaio NY 14222

\section{Bulletin Board jervices}

National Bureau of Standards

BB Services

(301) 948-5718

Bulletin Board Services

J. P. Emards

11 Ferry Lane West

Westport CT 06880

(\$26/yr, newslatter deveted to

supply and inro on BbS:

(203) 226-6967

\section{Public Do ain (ryee) Softuare}

A catalog of 6,000 pucl te domain programs ( $\$ 15 /$ diskette):

Folklife Terminai Cluo

Box 55;-8B, Co-op City sation

Bronx NY 10475

Free library software if you review it: Editor, SCIL

42 Grandview Dr.

Mt Kisco NY 10549

(914) 666-4099

Apple II

Compute: Learning Center (CLi)

P. 0. 20X 110876

Tacoma iA 98411

\section{Reate vatabase Search}

OCLC - (modem and printer prov..ded

free, runs on IBM PC, X.I, M300)

$1-800-848-5800$

A free demonstration of remote $D B$ searching:

Informatics General Corp.

Betty Davis (demo into)

1-800-638-0́595

Apple Library Users' Group Newsletter

Monica Ertel

Apple Computer Corp.

Doc. $26 B$

20550 Val ley Green Dr.

Cucertino CA 950:4

(408) 973-2552

(newsletter free) 
APPEDDEX IV

\section{Past Sponsors of the kilitary libratianz Horkstop}

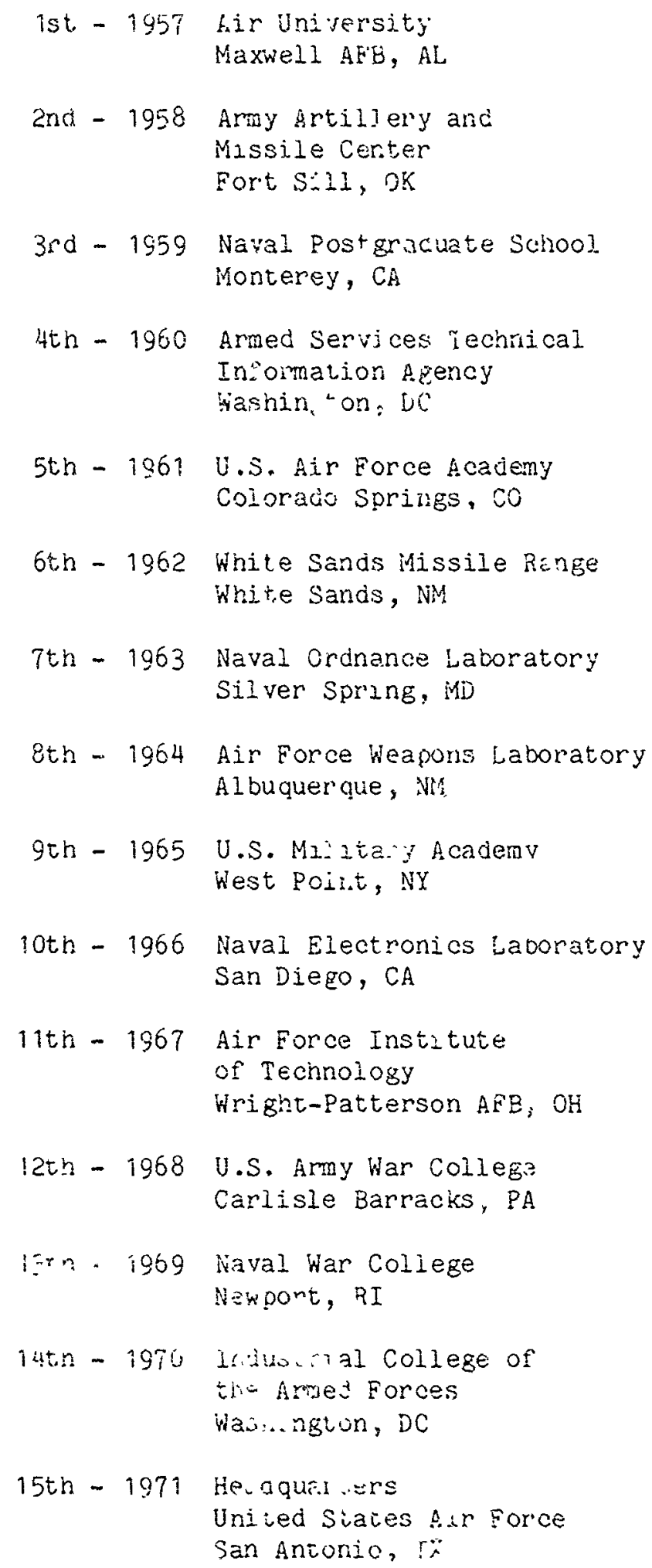

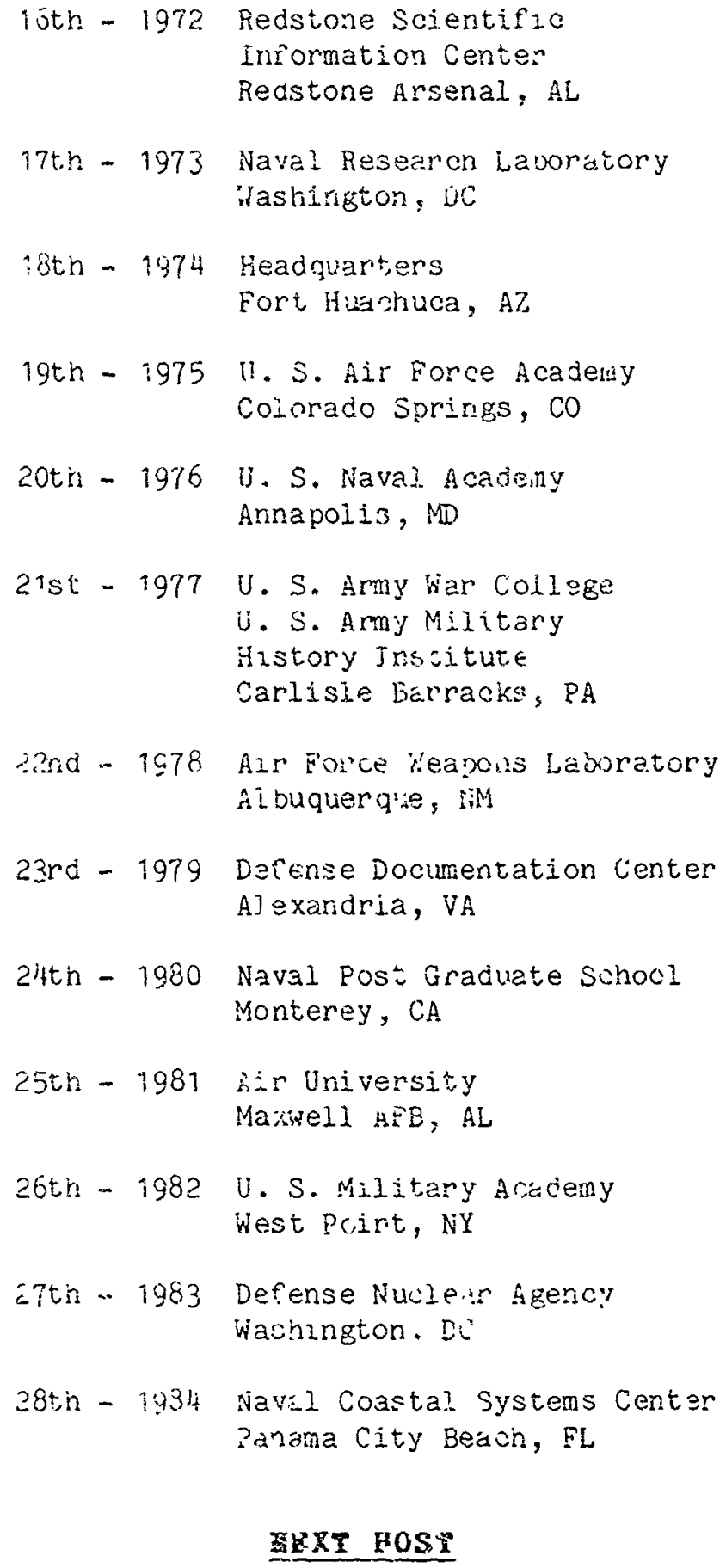


ÂPEENSIX V

\section{List of speakers}

Bonnett, Ms. Mary B.

Clover, Maj Willian $\mathrm{H}$.

Crouch, Dr. Keith

Duyle, Lt Col Bruford L.

Eller, Maj Jonathan R.

Forsyth, C1C Michael T.

Gonlike, Ms. Dorothy I

Klinefelter, Mr. Pau?

May, Col Jorn T.

Mçann, Lt Cul Thomas E.

MoCarron, Lt Col William E,

Fizzi, Lt Col Robert $\Xi$.

Rader, Dn. Freeman

Reed, CiC Carolyn M.

Riley, Mr, James $F$.

Schesfien, Lt Col Reiner h.

Schindler jorss, Dr. Barbana

- tevers, Maj Jonatr in is

Vajdd. Mr. John

Vaine'r, Mr. Normand L.
Army Library kanagement of fict

Departjent of Behari.rial jcienzes anj Leadership, united states Air Force dcadeny

Masisy Lilrary, Doyal Military solıege of Canada

Darector of Audic-Visual Services, Un ter Stat八s Aj. Forve Academy

Department $e_{i}$ Finglish, united States Air Force Acedemy

Cadet Wing, United Siated iix Force Acadeny

Assistant Air Force Liblarian

Defsrse iechnical Infomiticn Center

Vics-iean of the Facuicy, United States air gurce Academy

Jireotor of Research, United States Air Force Academy

Eepartmant of English, U:ited Stezes Air Force Academy

Department of Management, United States Air Fonce ncademy

Department of Ccmmunication, University of colorado

Cadet Wing, United States air For ce jucatemy

Executive Director of FaDi IilK, library of Congress

Director of Libra.des, Unjteci States üir Force Acariem:

Communications Consiltant

Director of the Education Research Computer Center, United States Air Fcree Academy

Wavy Department. Library

U.S. Artiy finco i.jbrary 
Ms Marcia Daridoff

Haval Technical Equipment Center

Technical Information Center - Code TIC

Bidg 2068

Orlando FL 32813-7100

(305) 646-5637// AY 791-5637

Ms Bonnie D. Davis

Naval Explosive Ordance Disposal Technology Center

Technical Library - Code 604

Indian Head $M D$ 20640-5070

(301) $743-4738 / 9$ if AV $364-4738 / 9$

Hs Altce E. Oolge

Paciflc Missile Test Center

Technical library. Code 1028

Point Mugs CA 93042

(805) 982-8192/56// AY 351-8192/56

Mr Steven R. Dorr

Oirector of Programs/Conferences DIA/DIC-R

Defense Intolligence colleoe

Washington if $20301-6111$

(202) 373-3341, 1 V 243-3341

Mr James C. Dorsey

U. S. Army Engr. Dist., Savanna

P. 0 . Box 889

Sayanna 6A $31402-0889$

Mr Kenneth E. Dowlin

Director

Pikes Peak Llorary ofstrict

$20 \mathrm{~N}$. Cascade Arenue

Colorado springs co 80901

(303) $473-2080$

Ms Frances M. Doyie

HO TRADOC Technteal Liorary

Bido. 133

Fort Monroe va 23651-5124

(804) $727-2821 / 2075 / /$ AY $680-2821$

Ms Anna B. Dumas

Ballistics HIssile Defense System Command

Technteal Library

P. 0. $80 \times 1500$

Huntsrilie AL 35807

(202) $895-3877 / 1$ AV $742-3877$

Ms toris Egge

Post Library, USAE

Fort Detrick MO 21701-5000

(301) $663-2807 / 1$ AY $3 \$ j-2807$

Ms Barbara A. Eller

Morale Support Actirities Division

ATTN: AFZA-PA-M

Fort Brago NC 28307-5000

(919) 396-6919// AV 236-6919

Hs Linda Evans

Rome Air Development Center Library

RADC/OOXT

Griffiss AFB IY 13441-5700

Prof Richard A. Evans

U. S. Naval Acadeny

Ninitiz Library

Annapolis MO $21402-5029$

(301) 267-2194// AY 281-2194
Ms Barbara Everidge

office of Information Systems \& Tech-ology

Defense Technical Information Center

Cameron Station, 81005

Alexandria $V A$ 22304-6145

(202) 274-5367 // AV 284-5367

Ms Holly Beth Ewan

Air Unversity Library

Maxwell AFB AL 36112

(205) $293-2237 / 1$ AV $875-2237$

Mr Donley D. Eyolfson

3420 TCHTG/TTMRL

LOWPY AF8 CO $80230-500$ :

(303) $370-5351$ if av $926-535$ !

Ms Valerte o. Fashion

U. S. Army iransportation Technical information Q Research center

ATTK: ATSPO-SEF-

Fort Eusetis YA $23604-5450$

$(804) 878-4126 / 5563 / 1$ AV $927-4126$

As Mary Finlay

Moblle Command headquarters

St-Hubert, Quebec, Canada

J3Y 5 TS

(514) $443-7242 / 7$ AY $621-7242$

Ms Bar'sur Fox

U. 5. Army Enor. Dist.. Hew Orleans

P.0. Box 60267

New orleans LA $70160-0267$

(504) $862-2558$

Mr Thonas A. Gallart

Morale Support Activities (Panama)

Drawer 940

APO MIani 34004

(517) 87-3361 (Pan.)/AV313-287-3361

Hs Lynn Gera

Library. Nalter Reed Army Institute of Research

Walter Reed Army Medical Cencer

Washington DC $20307-5100$

(202) $576 \cdot 3314 / /$ AY $291 \cdot 3314 / 3416$

Ms E. H. Glldersleeve

Liorary

AF GL/SULL

HansCOM AFB MA $78235-5000$

(617) 861-4895/1 AV 478-4895

Ms Patricia H, Gipe

Liorary oirector

Defense Systers Management College

Fort Be?voir VA $22060-5426$

(703) $664-2732 / /$ AV $354-2732$

Ms Esther Ruth Godbey

Base Librarian

$475 \mathrm{ABH} / \mathrm{SSL}$

APO San Francisco $96328-5000$

$(0425) 52-2511 \times 5-7490(\mathrm{Jpn})$ AV 225 -

Ms Gay D. Goethert

Superyisor. Technical Library

AEDC:DOS, Mail Stop 100

Arnold AFS TN $37389-9998$

$V I-3(615) 454-4429$ II AV $340-4429$ 
Ms Dorothy A. Gohlke

Asst. Afr Force Librarlan

HQ AFMPC IMPC SOL

Randolph AFB TX 78150-600

(512) $652-3037 / /$ AV $487-3037 / 4589$

Ms Suse Goodman

Air University Library

(AUL/LSS)

Maxwell AFB AL 36112-5564

(205) 293-2504// AY 875-2504

Ms Donna K. Griffitts

Jotht Medical Library

offices of the Surgeons General, USAIUSAF

Pentagon, Room 1B-473

Washington DC $20310-2300$

(202) 695-5752 if AV 225-5752

Ms Marind Griner

U. S. Army Soldter support Center

Post Llbrary. Blda 31

Fort. Den Harrison in 462 is-5100

(317) $542-4958 /$ AV $699-4958$

Hs Loutse L. Hall

Space ind Warfare Comand. Unted States Wary L lorery - Code 7033

Washington of 20363-5100

(202) $692-8771 / 2$, AV 442-8771/1482

Mr David R. Hanna

Naval inderwater Systens Center

Techntcal Library - Code 0213

Hew London Laboratory

Hey Lendon CT $08320^{\circ}$

(203) $447-4276 / /$ AY $636-4276$

Hs Martlyn Harned

Techntcal Library

Haval Air Systen Comand

AIR 723

Yashington OC 20361

(202) 692-9006/1 AV 222-9006

Ms Janice Hatt

NOHO Library

101 Colonel By Crive

ottawa. Canida

KiA ox 2

(613) 995-0831//AY 676-0831

Mr Terry L. Hawk ins

Chief. Authority Library

Air University Library (AUL/LD)

Maxwell AFB AL 36112-5564

(205) $293-2291 / 1$ AV $875-229$

Ms Judy A. Hawthorne

Command Librartan

HO SPACECHO IMPSL

Peterson AFB CO 80914-5001

(303) $554-5671 / 1$ AV 692-5671

Hs Karen Hayward

Fort Dix General Library

$81 d y$ 560: Pennsylvania Are.

Fort Dix NJ oe640

(609) $562-4858 / /$ AV $944-4858$

Mr Ismail Haznedari

COR, U. S. Army ARDC

ATTH: SMCAR-TSS (Mr Hazendari)

Bidg 59

Dover MJ 07801-5001

(211) 724-3316// AY $880-724-3316$
Ms Helen L. Helton

AFIT Library (AFITILOC)

Blidg. 640, Area 8

Wright-Pattersnn AFB OH 45433-0583

(515.) 255-4191//AV 785-5894

Hs Ruth E, Hodge

Chief Technical Services Branch

U. S. Army Military History Institute

Carlisle Barracks PA $17013-5008$

(117) $245-3632 / 1$ AV $242-3632$

Ms Jean Hort

Base Libriry

317 CS6/SSL

Pope AFS NC 28308-5225

$(919) 304-2791 / 1$ AV $486-2791 / 2195$

Or Marshal J. Hughes

Hayel Surface Neapons Center

Techntcal Llorary. Code E23

Danioran Laborteory

Danloren VA 2244 .

(703) $653-8994 / 1$ AV $249-8994$

Ms Mary E. Hunter

Cor, U. S. Army Miss lie Command

ATTM: AMSAI-YOL (Ms Hunter)

Redstone Arsen l AL 35898-5500

(205) 876-5305/1 AV 745-530s

Mr Peter lothof

Maval Research Laboratory

Ruth H. Hooker Technical Library

Code 2620

Washington DC 20375-5000

(202) 768-2357--AY 297-2357

Ms Joan E. Ingersoll

Naval Ocean Systems Center

Techntcal Librartes Branch

code 964

San Diego cA $92152-5000$

(619) $225-6623 / 1$ AV $933-6623$

Mr Duane A. Johnson

Command ibrarian

HO ATC IOPSOL

Randolph AFB TX 78150-50n!

(512) $652-3410 / 1$ AV $487-3410 / 2573$

Ms Ida Johnson

U. S. Army galitistic Research Laboratory ATTH: $A M \times B R-O D-S T$

Bidg 305

Aberdeen Proving Ground MO 21005-5066

AY $298-2125$

Ms Joinn $x$. Johnson

USAF FHS/COAL

Nell is AFB NY $89: 91-5000$

(752) $643-4970,1$ AV $682-4970$

Ms Sharon Johnson

Fitzsinons Army Medical Center

Medical Library

Aurora CO 80045-5000

(303) $361-3378 / 1$ AV $943-3378$

Ms Yyonne A. Kinkaid

Chief, Techaical Information

HO AFSC / MPSLT

Andrews AFB OC 20334-5000

(301) 981-2019// AV 858-2019 
Mr Paul Klinefelter

ATTN: OTIC-Y

Cameron jtation

Alexandrta YA 22314

(202) 274-6434 I/ av 284-6434

Ms Theresa J. Knaslak

Defense Institute of Security Assistance Management/DaL Butlding las

Area $B$

Hright-Patterson AFB OH 45433

(513) $255-5567 / /$ AV $785-5567$

Ms Gafl Knudtson

Command Librarian

HQ MACIOPSRL

SCOtt AFB IL 62225-5001

(618) $256-3228 / /$ AV $\$ 76-3228$

Mr Bohden 1. Kohutlak

U. S. Army Har College

ATTN: AHCSL

Carlisle Barracks PA 17013-5050

(71) $245-3660$ l, AV $242-3660$

Ms Betty Rroft

DOO OCHAMPUS Ltbrary

fitzimimons Army Medical Center

Aurort CO 80045-6900

Hs Lynda Kuntz

U. S. Army Concepts Andysis Agency

Technteal Library
8120 Woodmone Ave

Bethesda MD 20814-2797

(301) $295-1531 / 1$ AY

Mr Robert B. Lane

Director

Air Unfversity Library (AUL/LO)

Maxwell AFB AL $36112-5564$

(205) 293-2606//AV 875-2606

Mr Ernest P. Laseter

Liorarian

AFLMC $/ X R$

Blog. 205

Gunter AFS AL $36114-6693$

(205) $279-4830$ IV AV 446-4830

Ms Nancy L. Lomen

Baje Library

360 CSG/SSL, Bldg. 2427

Ht Home AFB 10 83648-5000

(208) $828-2111$ ext $2544 / /$ AV 857 .

Or Arlene Luster

Comand librarian

HQ PACAF IOPSRL

HickAm AFB HI $96853-5001$

(808) 449-9831/1 AV -9831

Ms Jean E. Malach

Canadian Land forces Command and staff College

Fort Frontende Library

Kingston, Ontario. Canda

K $7 \times 2 \times 8$

$(613)^{2} 545-5813 / 1$ AV $270-5813$

Mr Robert M. Malone

Naval Air Propulsion Center Technical Library

P. D. Box 7176

Trenton HJ 08628-0176

(609) $896-5609$ /I AV $443-7609$
Ms Kathryn E. Marshall

ANS Technical Library

USAFETAC ILD

SCott AFB IL 62225-500

(518) $256-2625 / /$ AV 576-2625

Mr Abbott W. Martin

Command Librarian

HQUSACE ATTH: DAEK-ASZ-5

Washington oC 20314-1000

(202) 272-0665 il AV 285-0665

Ms Margaret Mertinez

Liorary Oirector

Defense Communtcations Agency - Code $H 396$

Heshington DC 20305-2000

(202) 692-2468 Ii AV 222-2468

Ms Christel 6. Marton

COR, USAADAC Fort 81 is

Morale Support Division Center Llorary

-log 2

Fore bi13s TX 79916-5137

(915) $568-7705 / 1$ AV $978-7705 / 6736$

Ms Regind A. Mayton

Air University Library

(AUL/LS). Bido 1405

Maxwell AFB AL 36312-5564

(205) $293-2474 / 1$ AY $875-2474$

Hs Helen C. McClaughry

Bese Liorary

3415 th AB Group/55L

Lowry AFB CO $80230-5000$

(303) $370-3093 / 1$ AY $926-3093 / 3836$

Ms Barbara Melaughi in

U. S. Army Harry Oiamond Laboratories

ATTH: OELHO-TA-L

2800 Powder Mill Road

Adelphi Ho 20783

Av $290-2536$

Ms Lee R. Mclaughlin

Academy Libraries

HO USAFA/OFSEL

U. S. Air Force Academy

Colorado Springs CO $80840-5721$

(303) 472-4654 I/ AV $259-4654$

Mr Gregg Melton

AF GL/SULL

Hanscom AFB MA $01731=5000$

(617) $861-4895 / /$ AY $478-4895$

Mr Frank Mercugliano

Supervisor of Shipbuilding Conversion and Repair, USM Technical Library - Code 245

95 Summer St.

Boston MA 02i45-2181

(617) $451-4695 / /$ aV $955-4695$

Mr Roger Mlller

Chlef Library Branch. MSA

ATTN: AFZC-PM

Fort Carson CO BO913-5000

(303) $579-2842$ /I AV $697-2842$

Ms Clara Miller

Marine Corns Technical Library

Headquarterz Marlne Corps (Code LMA-1)

Washington DC $20380-0001$ 
Ms Dorothy A, Gohlke

Asst. Air Force Librarian

HQ AFMPC/MPCSOL

Randolph AFB ix 78150-600

(512) $652-303 ? / /$ AV $487-3037 / 4589$

Ms Suse Goodman

Air University Library

(AUL/LSS)

Maxwe 11 AF8 AL $36112-5564$

(205) 293-2504 IT AV 875-2504

Ms Oonna K. Griffitts

isint Medical Library

Offices of the Surgeons General, USA/USAF

Pentagon, Room 18-473

Hashington OC 20310-2300

(202) 695-5752 // Ar 225-5752

Ms Marina Griner

U. S. Army Soldier support Center

Post Library, Bldg 31

Fort Ben Harrison IN $46216-5100$

(317) 542-4958// AY 699-4958

Ms Louise L. Ha ll

Space and Varfare Command, United States Nary

Library - Code 7053

Washington DC 20363-5100

(202) 692-8771/2 / AV 442-8771/1482

Mr David R. Hanna

Naval Underwater Systems Center

Technical Library - Code 0213

New London Laboratory

New London CT 06320

(203) 447-4276// AY 636-4276

Ms Marilyn Harned

Technical Library

Naval Air System Command

AIR 723

Washington OC 20361

(202) $692-9006 / /$ AV $222-9006$

Ms Janice Hatt

NOHQ Library

lol Colonel By Orive

Ottawa, Canada

KlA OK2

(613) 996-0831// AV 676-0831

Mr Terry L. Hawkins

Chief, Authority Library

Air University Liorary (AUL /LO)

(205) $293 \cdot 2291 / /$ AY $875-2291$

Ms Judy A. Hawthorne

Command Librarian

HO SPACECMO/MPSL

Peterson AFB CO 80914-5001

(303) $554-5671 / /$ AV $692-567$

Ms Karen Hayward

Fort Dix General Library

Bldg 5601 Pennsylvania Ave.

Fort Dix NJ 08640

(609) $562-4858 / /$ AV $944-4858$

Mr Ismail Haznedari

COR, U. S. ATMY ARDC

ATTi: SMCAR-TSS (Mr Hazendarl)

Bldg 59

Dover HJ 07801-5601

(201) 724-3316/\% AY 880-724-3316
Ms Helen L. Helton

AFIT Liorary (AFIT/LOC)

Bidg. 640 , Area 8

Wright-Patt=rson AFB OH $45433-6583$

(515.) $255-4191 / /$ AV $785-5894$

Ms Ruth E. Hodge

Chief Technical Services Branch

U. S. Army Military History Institute

Carlisle Barracks PA $17013-5008$

(717) $24^{5}-3632 / 1$ AV $242-3632$

Hs Jean Hort

Base Library

317 CSG/SSL

Pope AFB HC 28308-5225

(919) 394-2791// AV 486-2791/2195

Or Marshal J. Hughes

Naval surface Weapons Ceuter

Technical Library - Code 523

Dahlgren Laboratory

Dahlgren VA 22448

(703) 663-8994// AY 249-8994

Ms Mary E. Hunter

Cor, U. S. Army Missile Command

ATTH: AMSMI-YOL (Ms Hunter)

Redstone Arsenal AL $35898-5500$

(205) 876-5305// AY 746-5305

Mr Peter Imhof

Maval Research taboratory

Ruth H. Hooker Technical Library

Code 2620

Washington OC 20375-5000

(202) 768-2357--AV 297-2357

Ms Joan E. Ingersoll

Neval ocean Systems Center

Technical Lioraries Branch

Code 964

San 01ego CA 92152-5000

(619) $225-6623 / 1$ AV $933-6623$

Mr Duane A. Johnson

Command Librarian

HQ ATC/OPSOL

Randolph AFB TX 78150-5001

(512) $652-3410 / / A V 487-3410 / 2573$

Ms lda Johnson

U. S. Army Ballistic Research Laboratory ATTII. AMX8R-00-5T

Bldg 305

Aberdeen Proving Ground MO 21005-5066

AV 298-2125

Is Joinn $K$. Johnson

USAF FUSICOAL

Nell is AFB NY $89191-5000$

(702) $643-4970 / /$ AV $682-4970$

Ms Sharon Johnsco

Fitzsimons Army Medical Center

Medical Library

Aurora CO 80045-5000

(303) 361-3378// AV 943-3378

Ms Yronne A, Kinkalo

Chief. Technical information

lio AFSCIMPSLT

Andrews $A F B$ oC 20334-5000

(301) $981-2019 / /$ AV $358-2019$

VI-4 
Mr Paul Klinefelter

AIIll: OTIC-V

Cameron Station

Alexandria $V A$ 22314

(202) $274-6434 / /$ AY $234-6434$

Ms Theresa J. Knasiak

Defense institute of Security Assistance Maragement/DAL Bullding 125

Area $B$

Wright-Patterson AFB OH 45433

(513) 255-5567//AV 785-5567

Ms sail krudtson

Comiand Liorarien

HO MIC IOPSRL

Scott AFB iL $52225-5001$

(618) $256-3228 \quad 1 /$ AV $576-3228$

Mr Bohdan i. Kohutiak

U. S. Army War College

ATrN: AWCSL

Carlisle Barracks PA 17013-5050

(717) $245-3660 / /$ AV $242-3660$

Ms Betty Kraft

DOD OCHAMPUS Library

Fit.25immons Army Medical Center

Auror Co $80045-6900$

Ms Lynda Kuntz

U. S. Army Conce $s$ Analysis Agency

Technical Library

8120 Woodmont Ave

(301) $295-1531 / 1$ AV

Mr Rotert 8. Lane

Director

Air University Library (AUL/LO)

Maxwell AFB AL $36112-5564$

(205) $293-2606 / /$ AV 875-2606

Mr Ernest P. Laseter

Librarian

AFLMCIXRL

Bidg. 205

Gunter AFS AL 36114-6693

(205) $279-4830 / /$ AV $446-4830$

Hs llancy L. Lomen

Base Librar

$366 \mathrm{CJG} / \mathrm{SSL}, \mathrm{Bldg} .2427$

Ht Home AFB $10 \quad 83648-5000$

(208) 828-2111 ext 2544 // AV 857-

Or Arlene iuster

Command Librarian

HO PACAF /OPSRL

HICKan AFB HI $96853-5001$

$(808) 449-9831 / 1$ AV -9831

Ms Jean E. Malach

Canadian Land Forces Command and Staff College

Fort Froritenac Library

kingston. Ontario, Canada

K $7 K 2 \times 8$

(613) $545-5813 / /$ AV $270-5813$

Mr Robert M. Malone

Gaval Air Propulsicn Center Technical Library

P. $0.80 \times 7176$

Trentun $11 \mathrm{j} 08628.0176$

(609) 8\$6-5609// AV $443-7609$
IIs Kathryn E. Marsnall

AWS Technical liorary

USAFETAC/LD

Scott AFB IL $62225-5001$

$(618) 256 \cdot-2625 / /$ iV $576-2625$

Mr Aboott W. Martin

Command Liorarian

HQUSACE ATYM: DAEN-ASZ-S

Washington OC 20314-1000

(202) $272-0665$ i/ AV 285-0665

Ms Margaret Martinez

Liorary Oirector

Defense Communications $20305-2000$

(202) 692-2458//AV $222-2468$

Ms Christel G. Marton

CDR, USAADAC \& Fort BIISS

Morale Support Division Center Library

Bidg 21

Fort Bliss TX 79916-5137

(915) 568-7705// AV $978-7705 / 6735$

Ms Regina A. Mayton

Air University Library

(AUL/LS), Bldg 1405

Maxwe11 AFB AL $36112-5504$

(205) $293-2474 / /$ AY $875-2474$

Ms Helen C. McClaughry

Base Library

3415 th $A B$ Group/S5L

Lowry AFB CO 80230-5000

(303) $370-3093 / /$ AY $926-3093 / 3836$

Ms Barbara McLaughin

U. S. Army Marry Diamond Laboratories

ATrii: DELHO-TA-L

2800 Powder Mill Road

Adelphi MO 20783

AV $290-2536$

Ms Lee R. Mclaughlin

Academy Lioraries

HQ USAFA/DFSEL

U. S. Air Force Academy

Colorado Springs CO $80840-5721$

(303) 472-4654// AV 259-4654

Mr Grego Melton

AFGL/SULL

Hanscom AFB MA 01731-5000

(617) 861-4895// AV 478-4895

Mr Frank Mercugliano

Supertisor of Shipbuilding Conversion and Repair, USi

Iechnical Library - Code 245

495 Summer St.

Bostor MA 02145-2181

(617) $451-4695 / /$ AV $955-4695$

Mr Roger Miller

Chief Lubrary Branch, MSA

ATTN: $A F Z C-P M$

Fort carson Co $80913-5000$

$(303) 579-284211$ AV $697-2842$

Ms Clara Miller

Marine Corns Technical Library

Headquarters Harine Corps (Code LMA-1)

He ddquarters har ine corps

(202) $694-1997 / 1$ AV 224-1997/2047 
Mr Anorew llinjuras

Post Librarian

ATTK: AFZOll-MSA-libra-y

Presidio of San Francisco DA U4l2:-5000

(415) $561-3448 / /$ A) $386-3448$

Mr Lee Missavage

base ilorary

/ SSL

little Rock AFB AR $12009-5000$

(201) $9(8-69 \%), 1$ AV $731-6979$

Ms Marcia Mohn

Post Library

ATTN: AFZC-PM (Lioraly Branch)

Fort Carson CO $80913-5000$

(303) 575-2350// AV 691-2350/2842

Ms Mary Jane Mongeon

AFGL Research Litrary

AFGL I SULLA

Hariscon AFE MA 01731-5000

(617) $86 !-4768 \%$ AV 787-4768

it: Oavia J. Menroe

Chief, Technical Libuary

ATIV: AMCONA-ML, RA $7 S 35$

5001 Eisennower Arenue

Alexandria if 22333-0001

$\{202\} 274-815$ ? II AV 284-8152

Ms Eveiyn 3. Monroe

Tecnnical Library, 8109 i27s

FCESSA, Dan NeCk

virginia gench da 23451.5300

(804) $433-7648 / /$ AY $433-7648$

Ms Donna tot

Liorarian, PliR, wondon

Box 14 - EOAFH-CI

FPO Hew York WY 09510

$0 !-409-45 i 1$ (Eng) II AV $235-4511$

its Theresa G. Munson

Morale Support Eivision, Post Library

Bidg 46

Carlisle 8arracks PA 17013-5002

(717) $245-3718 / /$ Ai $242-3718$

Ms C. E. Murohy

Canadian Forces Colliege Liorary

215 Yonge Bivo

Toronio. Canasa

M5M 349

(416) $484-5742$

Ms Rargaret M. Hurphy

U S Army Materials \& Mechanics Researcn Center Technical library

Watertown IAA 02172-000!

(617) $923-54501 /$ AV $955-5460$

Ms Gall $\|$ isula

Armed Forces Staff College

ATTN: Liorary

Norfolk, $V A$ 235:1

(804) $444-532 ! / /$ RV $554-5321 / 5: 55$

Ms Loulse Hyce

Library Program Oirector

ATTH: AFPR-CFA

Fort McPherson GA 30330-6000

(404) 362-3100,1/ AV 797-3100 lis Phyllis nrtutay

AQ, rmy Materiel Command

AII AMCIM-RF

500 : E*senhowe? Avenue

Alexar.ria VÂ 22333-000

(202) $274-808 i$ /1 AV $234-5087$

Ms jeanne ower

Plains and Peaks library System

Brodanarket bquare, Sulte ia

1761 South ath Street

colorado Spring; ce 80906

(303) $473 \cdot 3417$

Ms rarolyn pate

CÓn, USAFAC 3 fort $\$$

Horale Support Division, Nye Liorary

1640 Randoloh Roed

Fort Si:l OK 73503-5100

(405) $351-5111$ i) AV $639-5111 / 3150$

1:- Ornella L. Pensy

U. S. A.my inteiligence School, ft Devoris ATTM. ATSI-ETO-L

Fort Devens MA 01433-6301

$(6,7) 796-3413 / 67 / /$ AV $256-3413 / 67$

Ms Patricia $M$. Pepin

in ief, Library Branch

Hood Technical Library

Aberdeen Proving Ground Mo $21010-5425$

(s01) $671-4135 / /$ AV $584-4135$

Ms llarlow Peters

Chief liorarian

SO USAFE/DPSLC

APO llew York 09012

$0631-535-6752$ (K Ger) / AY 489-6752

Ms Darieng Price

HO $M A C / O P S L$

Scott AFE IL $62225-5001$

Mr Lawrence E. Rardall

U. Silitary ACademy

Vest po nt ity $10996-5000$

(914) $938-3833 / /$ AV $688-3833 / 2209$

Ms Caroline Ray

AFHALIGLISL

Bidg 22

Wright-Datterson AFB OH 45432

(5i3) $255-3630 / /$ AV $785 \cdot 3630$

Ms Aja liarkel Razuany

HO PACAF 10 PSOL

Hickam AFB 4! 36852-500

(808) 449-2831// AV

Ms Myrtle J. Rilodes

Naval Coastal Sy,tems Center

Technical Information Services Branch - Code 6120

Panand city $\mathrm{FL} 32407$

$19041234-4321 / 1$ AV $436-4321$

Ms Donna Richardson

efence Research Establishment At iantic

P. $0.80 \times 1012$

Dartmouth, Hova Scotia, Canada

B2Y 327

$y I-6 \quad(902) 426-3100$ 
Mr James P. Riley

Executive Director, FEJLiHK

$G-171$, Main Building

Liorary of Congress

Hashington $0 \mathrm{C} 20540$

(202) $287-6055 / 6 / 16454 / 5$

Capt james A. Robb

Acadeny Libraries

HO USAFAIDTSE:

U. S. Air force Academy

r.o orado springs Co $80840-5721$

(303) $472-2590$, I AV $259-25 \div 0$

Ms Pearl 0. Rodinson

Naval Snios Systems Engineertre station

Technical Litrary. Code 0l2f

Bidg 619

Philadelphia PA $19112=5083$

(215) $952-7078 / 7816 / /$ AV $444-7078$

IIs Ruth Rogers

Havd Aerospace Medical Institute Licrary - Code 012

Bidg 1953

Pensocola $C_{L} \quad 32508-5600$

$(904) 452-2256 / /$ AV $922-2256$

MS Alice ROY

HQ TAC IOPSRL

Langley AFB YA $23+65$

(804) 764-3584,//AV $432-3584 / 3403$

Ms Haria Ruckman

Fleet Combat Direcioion systems Susoort Rctivity

Dam Heck Technica! Litiary - Code 42

Bulloing 127 South

Virginiá Beach VA 23461-5:00

$(804) 433-6532 / 6374 / / A V 433-6374 / 7648$

Mr J. Thomas Russeil

Library Director

Mational Defense University

Fort Leslie j. MCNair

Washington of 20319-6000

(20人) 475-1905// AV 225-1905

Ms Suzanne $M$. Ryder

Naval Air Station

liaval Air Test Center Sentral Library - Code 62

Patuxent River MO 206?0

(301) $863-1930 / / \times 356-1930$

Ms Mary Lou Saver

Comand tibrarian

HO SAC/OPSOL

Offutt AFB HE $68113-5001$

(402) $294-2223 / 1$ AV $271-2223 / 2367$

its Laurel B. Saunders

US Army White Sands Missile Range

ATTN: STEHS-TE-TL

White sands Missile Range MM 88002-5029

(505) $678-1317 / 1$ AV $258-1317$

Lt Cn! Reiner H. Schaeffer

Academy Librarles

HO USAFAIOFSEL

U. S. Aur forte Academy

Colorardo Springs Co $80840-5721$

(303) $472-2590 / 1$ AV 259-2590

Prof Earl R. Schwass

llaval Var College

Lisrary - Code E

hewport RI 02841

(401) $841-2641 / 1$ AV $948-2641$ its nimeliek. Sefzon

Nutale Supocrt ACtivities

Post witrats, elig 404

iur: nami'is

Brsotlyn ily $11252 \cdot 5 \cdot 55$

(1) 630-:975, 11 ar $232-4375$

Ms ieslie $5 * 30 \mathrm{Cr}$

US 2 MEOOAS

Medical L-ariry

fort fevens ifa $01333-640$ !

Hs Ruth $\therefore$ Seidman

Air Force Geopnysics lab

Research Library, AfGLisuLL

Hanscom AFg MA 01731-5000

(6!) 2514895 // A4 $478-4895$

Ms lickie inarp

U. S. Argy Enqr. Dir., Southwestern

1114 commerce st, Federal Building

Dallas ix $75242-0215$

(214) $767-2325$

Mr Al Sherlock

Girector. Technical information Center

U. S. Army Enor. Haterways ExE. Sta.

P. O. Box 531

vicksburg lis 39180-0331

6001, 634-2533, FTS (601) $542-2533$

Hs Regina "l. Sieben

Cnief, Technical Library

ATIII. AMSEL-ME-PSi

Fort Monmouth $1 \mathrm{H}$ 07703 5007

120:) $532-3298$ HI AY $992-1298$

Mis forothy E siegfried

irformation services oruup AFWAL/GLIS

Wright-Patterson AFB OH 45433-6523

(515) $255-7454 / 1$ AV $285-7454$

Nis $8 e: h E$, smith

Walter Reed Army Mealcal Center

Medical Liorary

Washington of 20307-5001

(202) 576-1238!I AV 29!-1238

MS voAn I. Stolley

U. S. Army Comand \& General Stafi College

Comoined Arms Research Library

ATTII: ATZL-SiNS-L

Fort Leavenworth KS 6u027-6900

(913) $684-4035 / /$ Ay $552-4035$

Mr james $x$. iancock

Chief, Library aranch

oefense itapoing Agency

Aerospace Center

St Louis AFS 4003118

(314) $263-4841$ / AV $693-4841$

Ms Deborah Thompson

PACAF Library Service tanter

HCKun AF 3 Hi 96853-5001

$(808) 449-2209 / 2110 / / \mathrm{AV}$

Mr Fred Food

Technical Services Division

USAT SAM/TSK

Brooks AFB IX 78235-5000 
Mr Albert G. Wast

Tectisical Program Manger

Technical information Birectorate

Defense Huclear Agency

wasinington $D C$ 22305-1000

(202) $325-7780$ /I AV $221-7780$

Mr Eiwood L. White

Air University Library

Haxwe: 1 AFB A! 36112

(805) $866.9745 / /$ AV 276-9745

(205) 293-200,6/A AV $875-2606$

Ms inyne A. Tysdal

Base Librarian

401 CSG/SSL

APo Hew York 09283

$011-34-1-205-7702$ (Spn) AV 314-723-

Mir Clyce H, Whicted Jr

Maval Mine Warfare Engineering Activity

Fechnical Library s Micrographics Division

Yorktown $Y A 2369 \mathrm{i}-5076$

(804) $887-4671 / 2 / /$ AV $953-3671 / 2$

Mr john E. Vajod

Navy Dept Library

Builoing 44

Hashington liavy Yard

Hashington oC 20374.0571

(202) $433-4132 / /$ AY $288-4132$

Ms Connie J. Wiey

AFGL Research Liorary

AF GL I \$ULLA

Hanscom AF itA $0 ! 731-5000$

(6ii) $8 \mathrm{ci}-4739$ i/ मे $478-4739$

Mr Normand L. Yarieur

Library

U S Army AREC

ATTH: SMCAR-TSS, Bldy 59

Dover IfJ $07301-5001$

(201) $724-2914 / /$ AY $880-291$.

IIs Mary B. Vick

Technical and Automated Services Branch

Pentagon Litrary

Room 14518, Pentagon

Washington ac 20310-60no

$(202) 697-1951$ /I AV 2i7-1951

Ms Alree:a Viehdorfer

Librarian

AFAFC Library/FL 7040

Donver CO 80279-5000

(303) $370-7566 / /$ AV $926-7566$

Ms Katharine B Hallace

Naval Oceanographic oifice

Haval Liorary. Code 4601

HSTl station

Bay Si.LOu's HS $39522-5001$
$(601) 683-5714$ H AV $485-4017$

Mr Gary Walter

Befense Language Institute

Academic Library, Blag bl8

Presidio of Munterey (A 93944-5007

AV $929-8572$

Me joyce C. Watlington

US Army Human Fngineering Laboratory

ATTN: Liorary, Bidg 453

Aberdeen Proving Ground M9 21005-5001

(301) $278-5899 / 1$ AV $298-5899$

Ms Stephanie Y. Hillams

Noval Intellioence support fenter

information Servize fivision - code 63

$430:$ :

Heshington DC 20390-5140

(202) 763-1778// AY 293-1478

Ms Orrirz L. Hoinowst

Admin Lib-arian

AFHRL'TSKL

BroCKS AFB IX 78235-5601

(512) $536-2051$ // AV 240-2651

Ms Caro? Hong

Mare ls land Naval Snipya.d

Technizal tórary - Code 206.13

STOP T-4/483

Va:iejo CA $94592-5100$

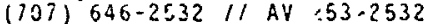

Ms Maty H. Wooten

Post Library, Bidg 38

Fort Campbell KY 42223-5000

Ay $635-5729$

Ms Barbara Wrinkle

Chief, Base Library Management Branch

HO USAFE IOPSL

AFO Hew York 0901

W. Ger $6371-57111$; AV $486-6895$

Ms Sandra 5 Young

Librariaa, rechnica Information Oirectorate Defense kus lear Agency

Hashington DC 20305-1000

(202) $325-7389 / 1$ AY $221-7389$

Ms Sylvia J. Webber

U. S. Army Intellígence Center \& school

Library, ATSI-TO-SFL

Fort Huachuca az $8561 j-7000$

(602) $538-7786 / /$ AV $879-7786$

Mr Egon A. Weiss

U. S. Military Acad my

Hest POint NY $109.16-5000$

(914) $938-2209$ /I AV $688-2209 / 3833$

DUS GOVERNMEN: PRINTING OFFICE 1986-676.001! 41042 